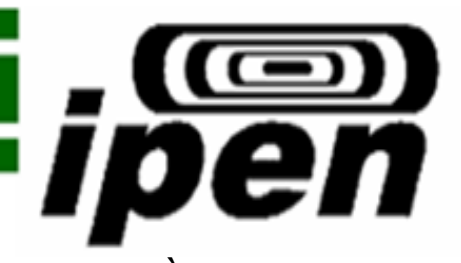

AUTARQUIA ASSOCIADA À UNIVERSIDADE DE SÃO PAULO

\title{
DENSIFICAÇÃO E CONDUTIVIDADE ELÉTRICA DA ZIRCÔNIA-ESCÂNDIA-CÉRIA
}

ROBSON LOPES GROSSO

Dissertação apresentada como parte dos requisitos para obtenção do Grau de Mestre em Ciências na Área de Tecnologia Nuclear Materiais

Orientadora:

Profa. Dra. Eliana Navarro dos Santos Muccillo

São Paulo

2012 


\section{ipen}

INSTITUTO DE PESQUISAS ENERGÉTICAS E NUCLEARES

AUTARQUIA ASSOCIADA À UNIVERSIDADE DE SÃO PAULO

\section{DENSIFICAÇÃO E CONDUTIVIDADE ELÉTRICA DA ZIRCÔNIA-ESCÂNDIA-CÉRIA}

ROBSON LOPES GROSSO

Dissertação apresentada como parte dos requisitos para obtenção do Grau de Mestre em Ciências na Área de Tecnologia Nuclear Materiais

Orientadora:

Profa. Dra. Eliana Navarro dos Santos Muccillo 
"Faça o que goste. Você não precisará de sábado e de domingo para descansar e no final do mês ainda pagam pra você se divertir".

(Crodowaldo Pavan) 


\section{Agradecimentos}

Primeiramente, gostaria de agradecer à Dra. Eliana Navarro dos Santos Muccillo pela oportunidade de desenvolver este trabalho, pelos ensinamentos, dedicação e paciência.

Ao Dr. Reginaldo Muccillo pelos ensinamentos, discussões e pelas medidas de difração de rais $X$.

À CAPES pela bolsa de Mestrado.

Ao IPEN pela oprtunidade de realizar esse trabalho.

À FAPESP e CNPq pelo apoio financeiro.

Aos técnicos Pedro e Yone França pelo auxílio nos laboratórios.

À Dra. Eliana Arico e Dr. Fábio Fonseca pelas medidas de dilatometria.

Ao Celso Moraes e Dra. Flávia pelas imagens de microscopia eletrônica de varredura. Ao Glausson pelas imagens do FEG.

Ao Marcelo Bertolete e Dra. Izabel Machado pela sinterização assistida por campo elétrico.

À Dra. Dalva Faria e Claudio Hanashiro pelas medidas de espectroscopia Raman.

Ao pessoal do CCTM: Victor Ranieri, Talita Fujimoto, Olavo Oliveira, Dra. Érica Caproni, Dr. Fábio Camargo, Dr. Eduardo Caetano, Dr. Ariston Mello e Dra. Sandra Tadokoro.

Agradeço especialmente à minha mãe, ao meu tio Júlio e a familiares que me incentivaram e ajudaram.

À Raquel Rinke pelo incentivo, apoio e paciência. À família Rinke Santos pelo apoio e momentos de descontração.

Aos amigos e colegas de grupo de pesquisa: Shirley Reis, Rafael Batista, Tatiane Porfírio, Emanuelle Zangerolame, Mayra Gonçalves, Sabrina Carvalho pelas valiosas discussões, sugestões, apoio e pelos momentos de descontração durante o desenvolvimento deste trabalho.

À Dra. Renata Ayres Rocha e Dra. Eduarda Maria Soares de Carvalho Tomás pelas discussões e sugestões.

E a todos que direta ou indiretamente contribuíram para a realização deste trabalho. 


\title{
DENSIFICAÇÃO E CONDUTIVIDADE ELÉTRICA DA ZIRCÔNIA-ESCÂNDIA-CÉRIA
}

\author{
Robson Lopes Grosso
}

\section{Resumo}

Estudos recentes demonstram que o sistema cerâmico zircônia-escândia-céria (ScCeSZ) apresenta-se promissor para aplicações como eletrólito sólido em células a combustível de óxido sólido de temperaturas intermediárias de operação $\left(600\right.$ a $\left.800{ }^{\circ} \mathrm{C}\right)$. Neste trabalho, foi realizada a sinterização convencional, de duas etapas e assistida por campo elétrico do $\mathrm{ZrO}_{2}$ contendo $10 \%$ em mol de $\mathrm{Sc}_{2} \mathrm{O}_{3}$ e $1 \%$ em mol de $\mathrm{CeO}_{2}$ comercializado pela Fuel Cell Materials visando melhorar a densificação com reduzido tamanho médio de grãos. A condutividade elétrica de amostras densas de ScCeSZ sinterizadas pelos diferentes métodos foi investigada por espectroscopia de impedância. Diferentes condições de sinterização foram analisadas. A taxa de retração dos compactos é máxima a $1180^{\circ} \mathrm{C}$, determinada pela análise de dilatometria. Foi confirmado por difração de raios $\mathrm{X}$ que a adição de céria à zircônia-escândia promove a estabilização da fase cúbica à temperatura ambiente. No entanto, dependendo das condições de sinterização pode haver a formação de fases secundárias, as quais foram detectadas por difração de raios $\mathrm{X}$ e espectroscopia Raman. A sinterização assistida por campo elétrico promoveu a formação das fases cúbica e tetragonal. Considerando os métodos convencional e de duas etapas, para a obtenção do material cúbico monofásico é necessária uma seleção cuidadosa das condições de sinterização. Os valores de condutividade elétrica estão de acordo com as condutividades do ScCeSZ reportadas na literatura.

Palavras-chave: zircônia-escândia-céria, sinterização convencional, sinterização em duas etapas, sinterização assistida por campo elétrico, caracterização estrutural, condutividade elétrica. 


\title{
DENSIFICATION AND ELECTRICAL CONDUCTIVITY OF ZIRCONIA-SCANDIA-CERIA
}

\author{
Robson Lopes Grosso
}

\begin{abstract}
Recent reports show that scandia-and ceria-doped zirconia (ScCeSZ) is a promising material for application as solid electrolyte in solid oxide fuel cells operating at intermediate temperatures $\left(600-800{ }^{\circ} \mathrm{C}\right)$. In this work, $\mathrm{ZrO}_{2}$ containing $10 \mathrm{~mol} \% \mathrm{Sc}_{2} \mathrm{O}_{3}$ and $1 \mathrm{~mol}^{\circ} \mathrm{CeO}_{2}$ commercial powder (Fuel Cell Materials) was used to investigate the densification along with the mean grain size in specimens sintered by different methods: conventional, two-step sintering and electric field assisted sintering. The electrical conductivity of dense sintered specimens was studied by impedance spectroscopy. The linear shrinkage was followed by dilatometry. The maximum shrinkage rate of powder compacts was obtained at $1180^{\circ} \mathrm{C}$. X-ray diffraction experiments revealed that ceria stabilizes the cubic phase of scandia-doped zirconia at room temperature. However, secondary phases (rhombohedric and tetragonal) were detected by both X-ray diffraction and Raman spectroscopy depending on the sintering conditions. The field assisted sintering method resulted in specimens with cubic and tetragonal phases. In the case of conventional and two-step sintering methods, a careful selection of the temperatures and sintering times is essential to obtain a cubic single-phase material. Values of the electrical conductivity of ScCeSZ are in general agreement with those reported in the literature.
\end{abstract}

Key-words: zirconia-scandia-ceria, conventional sintering, two-step sintering, field assisted sintering, structural characterization, electrical conductivity. 


\section{Lista de Figuras}

Figura 1. Estrutura cristalina cúbica típica da fluorita................................ 2

Figura 2. Diagrama de fases do sistema $\mathrm{ZrO}_{2}-\mathrm{Sc}_{2} \mathrm{O}_{3} \ldots \ldots \ldots \ldots \ldots \ldots \ldots \ldots \ldots \ldots . . . . . . . . . . . . . .4$

Figura 3. Difratogramas de raios $X$ das principais estruturas cristalinas encontradas para o sistema zircônia-escândia. Faixa de $2 \theta$ entre (a) 20 e $80^{\circ}$ e (b) 73 e $76^{\circ}$.

Figura 4. Estrutura romboédrica $(\beta)$ da zircônia-escândia............................ 6

Figura 5. Gráfico de Arrhenius para a condutividade elétrica das principais estruturas encontradas na zircônia-escândia.

Figura 6. Condutividade elétrica em função do tempo para o ScSZ e 10Sc1CeSZ

Figura 7. Representação esquemática do desenvolvimento da microestrutura durante a sinterização. (a) Partículas soltas de pó; estágios: (b) inicial, (c) intermediário e (d) final

Figura 8. Ilustração da configuração do sistema de sinterização assistida por campo elétrico.

Figura 9. Representação do fluxo de corrente elétrica através das partículas.

Figura 10. Representação do perfil temperatura-tempo nos processos de sinterização (a) convencional e (b) em duas etapas

Figura 11. Temperaturas registradas durante o resfriamento do forno tipo caixa em função do tempo no intervalo entre (a) 0 e 150 min e (b) 0 e $35 \mathrm{~min}$

Figura 12. Ilustração de corte vertical do conjunto utilizado na sinterização assistida por campo elétrico.

Figura 13. Parâmetros registrados pelo equipamento de SPS durante a sinterização a $1200^{\circ} \mathrm{C}$ por 5 min

Figura 14. Ilustração do esquema de corte em amostras sinterizadas por SPS.

Figura 15. Fluxograma das etapas de caracterização do pó e das amostras sinterizadas pelos métodos convencional e de duas etapas.

Figura 16. Fluxograma das etapas de caracterização das amostras sinterizadas por SPS. 
Figura 17. Esquema do diagrama de impedância idealizado contendo três semicírculos...

Figura 18. Difratograma de raios $X$ do pó de ScCeSZ como recebido.......... 36

Figura 19. Micrografias do pó de ScCeSZ como recebido em aumentos de a) $50 x$, b) $100 x$, c) $500 x$ e d) $10000 x$.

Figura 20. Curvas termogravimétrica (TG) e de análise térmica diferencial (DTA), obtidas em atmosfera de ar sintético com taxa de aquecimento e resfriamento de $10{ }^{\circ} \mathrm{C} / \mathrm{min}$, do material como recebido.

Figura 21. Difratograma de raios $X$ do pó de ScCeSZ após ser submetido à análise térmica.

Figura 22. Retração linear do compacto de ScCeSZ e sua derivada............ 39

Figura 23. Curvas de densidade relativa em função da temperatura

Figura 24. Difratogramas de raios $X$ de amostras de ScCeSZ sinterizadas a várias temperaturas por tempo de patamar nulo na faixa de $2 \theta$ entre (a) 20 e $80^{\circ}$ e (b) 48 e $53^{\circ}$

Figura 25. Curva de densidade geométrica relativa em função do tempo para as temperaturas de sinterização estudadas por método convencional. Intervalo de tempo de (a) 0 a $15 \mathrm{~h} \mathrm{e} \mathrm{(b)} 0$ a $2 \mathrm{~h} . .$. .

Figura 26. Difratogramas de raios $X$ de amostras de ScCeSZ sinterizadas a várias temperaturas por 2 horas

Figura 27. Difratogramas de raios $X$ de amostras de ScCeSZ sinterizadas a $1200^{\circ} \mathrm{C}$ por vários tempos de patamar. Faixa de $2 \theta$ entre (a) 20 e $80^{\circ}$ e (b) 73 e $76^{\circ}$

Figura 28. Difratogramas de raios $X$ de amostras de ScCeSZ sinterizadas por tempos prolongados.

Figura 29. Micrografias da superfície de fratura da amostra de ScCeSZ sinterizada pelo método convencional a $1200{ }^{\circ} \mathrm{C}$ por tempo de patamar nulo. (a) Aumento menor e (b) maior.

Figura 30. Micrografias de amostras de ScCeSZ sinterizadas pelo método convencional: (a) $1200{ }^{\circ} \mathrm{C}$ por $0,2 \mathrm{~h}$, (b) $1200{ }^{\circ} \mathrm{C}$ por $2 \mathrm{~h}$, (c) $1250^{\circ} \mathrm{C}$ por $1 \mathrm{~h} \mathrm{e} \mathrm{(d)} 1300^{\circ} \mathrm{C}$ por tempo de patamar nulo.....

Figura 31. Micrografias de amostras de ScCeSZ sinterizadas pelo método convencional: (a) $1200{ }^{\circ} \mathrm{C}$ por $0,5 \mathrm{~h}$, (b) $1200{ }^{\circ} \mathrm{C}$ por $5 \mathrm{~h}$, (c) $1300^{\circ} \mathrm{C}$ por $0 \mathrm{~h} \mathrm{e} \mathrm{(d)} 1400^{\circ} \mathrm{C}$ por $0 \mathrm{~h}$. 
Figura 32. Tamanho médio de grãos em função da densidade hidrostática relativa de amostras sinterizadas pelos métodos convencional e duas etapas

Figura 33. Difratogramas de raios $X$ de amostras de ScCeSZ sinterizadas pelo método de duas etapas.

Figura 34. Micrografias de amostras de ScCeSZ sinterizadas em duas etapas: (a) $1200{ }^{\circ} \mathrm{C}+1070{ }^{\circ} \mathrm{C} / 5 \mathrm{~h}$, (b) $1200{ }^{\circ} \mathrm{C}+1100{ }^{\circ} \mathrm{C} / 5 \mathrm{~h}$, (c) $1200^{\circ} \mathrm{C}+1100{ }^{\circ} \mathrm{C} / 10 \mathrm{~h} \mathrm{e}$ (d) $1200^{\circ} \mathrm{C}+1100{ }^{\circ} \mathrm{C} / 15 \mathrm{~h}$.

Figura 35. Micrografias de amostras de ScCeSZ sinterizadas em duas etapas: (a) $1350^{\circ} \mathrm{C}+1200^{\circ} \mathrm{C} / 5 \mathrm{~h}$, (b) $1400^{\circ} \mathrm{C}+1200^{\circ} \mathrm{C} / 5 \mathrm{~h} \ldots$.

Figura 36. Difratogramas de raios $X$ de várias camadas da amostra de ScCeSZ sinterizada em duas etapas.

Figura 37. Fotografia das amostras sinterizadas por SPS

Figura 38. Fotografias das amostras sinterizadas por SPS cortadas. (a) Após primeiro corte e (b) amostras cortadas para caracterização.

Figura 39. Difratogramas de raios $X$ das amostras de ScCeSZ sinterizadas por SPS (a) antes do desbaste e (b) após desbaste.

Figura 40. Espectro Raman das amostras sinterizadas por SPS. (a) $1100^{\circ} \mathrm{C} / 5 \mathrm{~min}$, (b) $1200^{\circ} \mathrm{C} / 1 \mathrm{~min}$ e (c) $1200^{\circ} \mathrm{C} / 5 \mathrm{~min}$.

Figura 41. Difratogramas de raios $X$ das amostras de ScCeSZ sinterizadas por SPS e método convencional após serem submetidas a tratamento térmico a $900{ }^{\circ} \mathrm{C}$ por $4 \mathrm{~h}$

Figura 42. Micrografias de amostras de ScCeSZ sinterizadas por SPS: (a) $1000{ }^{\circ} \mathrm{C}$ por $5 \mathrm{~min}$ (fratura), (b) $1100{ }^{\circ} \mathrm{C}$ por $5 \mathrm{~min}$, (c) $1200^{\circ} \mathrm{C}$ por $1 \mathrm{~min}$ e (d) $1200^{\circ} \mathrm{C}$ por $5 \mathrm{~min}$.

Figura 43. Diagramas de impedância de amostras sinterizadas a $1200{ }^{\circ} \mathrm{C}$ por $0,5,5$ e $15 \mathrm{~h}$ obtidos a $380^{\circ} \mathrm{C}$. Os números $4,5,6$ e 7 correspondem ao $\log _{10}$ (frequência) para 0 correspondente ponto.

Figura 44. Diagramas de impedância de amostras sinterizadas pelos métodos convencional, de duas etapas e SPS obtidos a $380^{\circ} \mathrm{C}$. Os números 4, 5, 6 e 7 correspondem ao $\log _{10}$ (frequência) para o correspondente ponto.

Figura 45. Gráficos de Arrhenius para a condutividade elétrica do grão de amostras de ScCeSZ sinterizadas, em diferentes condições, pelos métodos convencional, de duas etapas e SPS. 
Figura 46. Gráficos de Arrhenius para condutividade elétrica do contorno de grão de amostras de ScCeSZ sinterizadas, em diferentes condições, pelos métodos convencional, de duas etapas e SPS.

Figura 47. Gráficos de Arrhenius para condutividade do contorno de grão corrigida pelo tamanho médio de grãos de amostras de ScCeSZ sinterizadas, em diferentes condições, pelos métodos convencional, de duas etapas e SPS.

Figura 48. Gráficos de Arrhenius da condutividade elétrica total do $11 \mathrm{ScSZ}$ e do ScCeSZ de diversas referências e sinterizado em diferentes condições no presente trabalho $\left.{ }^{*}\right)$.............................

Figura 49. Gráficos de Arrhenius para a condutividade elétrica total de amostras de ScCeSZ sinterizadas a $1400^{\circ} \mathrm{C} / 0 \mathrm{~h}$ e por SPS...... 


\section{Lista de Tabelas}

Tabela I. Valores de densidade hidrostática relativa $\left(\rho_{H}\right)$, tamanho médio de grãos $(G)$ e estrutura cristalina de amostras de ScCeSZ sinterizadas pelo método convencional.

Tabela II. Valores de densidade hidrostática relativa $\left(\rho_{H}\right)$, tamanho médio de grãos $(G)$ e estrutura cristalina de amostras de ScCeSZ sinterizadas em duas etapas.

Tabela III. Condições de sinterização por SPS e densidade hidrostática relativa $\left(\rho_{H}\right)$ das amostras.

Tabela IV. Tamanho médio de grãos $(G)$ das amostras sinterizadas por SPS.

Tabela V. Condutividade elétrica total encontrada a $450{ }^{\circ} \mathrm{C}$ para amostras de ScCeSZ sinterizadas em diferentes condições no presente trabalho $\left({ }^{*}\right)$ e de amostras de 10Sc1CeSZ, $5 \mathrm{Sc6CeSZ}$ e 8ScSZ de trabalhos reportados na literatura.......

Tabela VI. Valores de energia de ativação para o processo de condução dos grãos $E_{a} g$ e contornos de grão $E_{a} c g$ de amostras sinterizadas pelos métodos convencional, de duas etapas e SPS na faixa de temperatura de 300 a $450{ }^{\circ} \mathrm{C}$

Tabela VII. Valores de energia de ativação $\left(E_{a}\right)$ para o processo de condução das amostras sinterizadas a $1400^{\circ} \mathrm{C}$ por tempo de patamar nulo e por SPS 


\section{Sumário}

1. INTRODUÇÃO

Eletrólitos Sólidos ......................................................................

Sistema Zircônia-Escândia.............................................................. 3

Sistema Zircônia-Escândia-Céria ...................................................... 8

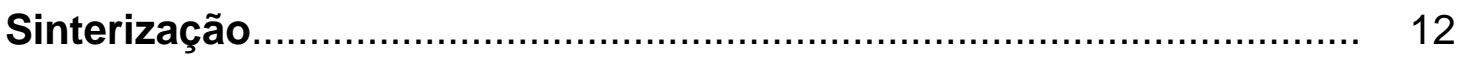

Algumas Técnicas de Sinterização............................................ 14

Sinterização em Duas Etapas............................................... 14

Sinterização Assistida por Campo Elétrico.................................. 16

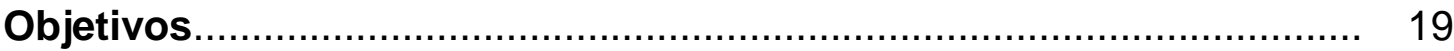

2. MATERIAIS E MÉTODOS ...................................................... 20

Material de Partida............................................................ 20

Elaboração dos Corpos de Prova ................................................... 20

Métodos Convencional e de Duas Etapas...................................... 20

Sinterização Assistida por Campo Elétrico ....................................... 22

Caracterização das Amostras........................................................ 24

Técnicas de Caracterização............................................................... 27

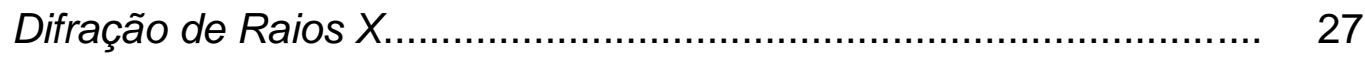

Análise Térmica................................................................................ 28

Densidade Aparente.............................................................. 29

Método Geométrico........................................................ 29

Método de Imersão............................................................... 30

Microscopia Eletrônica de Varredura............................................ $\quad 30$

Determinação do Tamanho Médio de Grãos............................ 31

Espectroscopia Raman........................................................... 32

Espectroscopia de Impedância.................................................... 32

Condutividade Elétrica ..................................................... 34

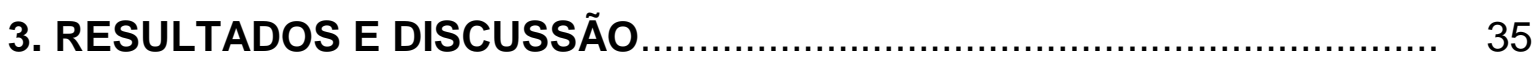

Caracterização do Material como Recebido...................................... 35

Sinterização e Caracterização dos Compactos.................................. 38

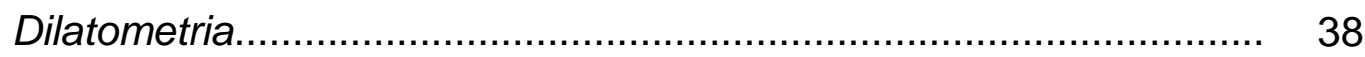

Sinterização Convencional....................................................... 39

Sinterização em Duas Etapas...................................................... $\quad 51$

Sinterização Assistida por Campo Elétrico...................................... 57

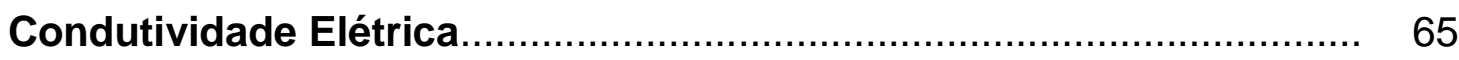

4. CONCLUSÕES

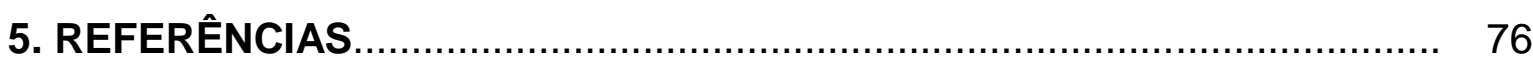




\section{INTRODUÇÃO}

Neste capítulo será feita uma abordagem sobre as principais características de alguns dos eletrólitos sólidos mais estudados e os mecanismos e processos de sinterização em estado sólido estudados neste trabalho. Por fim, serão detalhados os objetivos.

\section{Eletrólitos Sólidos}

Condutores de íons oxigênio formam uma classe de materiais funcionais com aplicações tecnológicas em diversas áreas incluindo sensores de espécies químicas, bombas de oxigênio, membranas permeáveis ao oxigênio e células a combustível para produção de energia ${ }^{(1)}$.

Para essas aplicações, uma de suas propriedades mais importantes é a condutividade iônica, que é influenciada por fatores, como pureza dos materiais de partida e parâmetros de processamento, tais como: introdução de aditivos, moagem e tratamentos térmicos (calcinação, sinterização e envelhecimento), que definem a microestrutura do material sinterizado.

Idealmente um eletrólito sólido é um condutor de uma única espécie química e um isolante eletrônico. Isso significa que a concentração de defeitos iônicos deve ser muito superior à de defeitos eletrônicos.

Para a grande maioria dos eletrólitos sólidos cerâmicos condutores de íons oxigênio, a condução, a qual é um processo termicamente ativado, ocorre por meio de sucessivos saltos dos íons oxigênio em posições vacantes na estrutura cristalina. Assim, um dos parâmetros mais importantes para a obtenção de alta condutividade é a concentração de vacâncias de oxigênio. Estas podem ser nativas (condutores intrínsecos) ou podem ser introduzidas por meio de substituições parciais convenientes (condutores extrínsecos). 
Poucos são os óxidos que apresentam altos valores de condutividade para o íon oxigênio. A alta mobilidade iônica, necessária para a obtenção de altos valores de condutividade, só é encontrada em óxidos com estruturas cristalinas específicas. As principais são ${ }^{(2,3)}$ : estrutura cúbica de faces centradas tipo fluorita, estrutura tipo pirocloro, estrutura tipo perovsquita e perovsquita modificada e estrutura tipo apatita.

Os óxidos de estrutura fluorita são os mais comuns e clássicos materiais condutores de íons de oxigênio ${ }^{(4)}$. A Figura 1 mostra uma representação da estrutura tipo fluorita. A estrutura do cristal consiste em uma rede cúbica de íons oxigênio rodeada por cátions. Os cátions são arranjados em uma estrutura cúbica de face centrada com ânions ocupando as posições tetraédricas. Isto leva a uma estrutura aberta com largos interstícios octaédricos vazios.

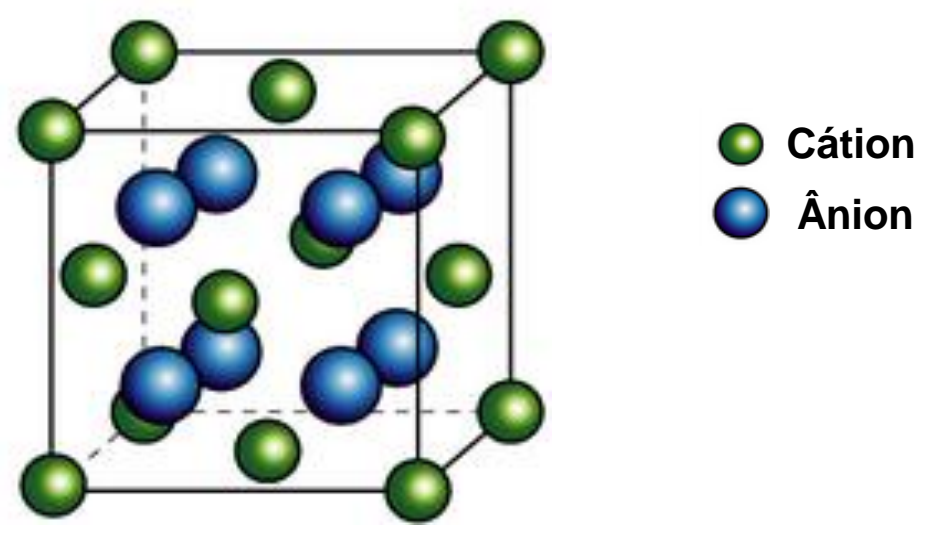

Figura 1. Estrutura cristalina cúbica típica da fluorita.

Os óxidos mais estudados pertencentes a essa família de materiais são a zircônia $\left(\mathrm{ZrO}_{2}\right)$ e a céria $\left(\mathrm{CeO}_{2}\right)^{(3)}$. A zircônia nominalmente pura é um condutor extrínseco de baixa condutividade para o íon oxigênio, devido às impurezas provenientes do processo de síntese ou extração. No entanto, a substituição parcial do $\mathrm{Zr}^{4+}$ por $\mathrm{Y}^{3+}, \mathrm{Ca}^{2+}, \mathrm{Mg}^{2+}, \mathrm{Sc}^{3+}$ e terras raras trivalentes, além de poder promover a estabilização da fase cúbica tipo fluorita numa ampla faixa de temperatura, introduz um número substancial de vacâncias de oxigênio, aumentando a condutividade iônica por algumas ordens de grandeza. Essas vacâncias são geradas como defeitos complementares devido a diferença de valência do cátion da rede e do cátion substituinte. 
Dessa forma, materiais à base de zircônia são amplamente utilizados como eletrólitos sólidos em células a combustível de óxido sólido (Solid Oxide Fuel Cell, SOFC) devido a sua elevada condutividade para o íon oxigênio e estabilidade química em condições de operação da célula. Nas últimas décadas, SOFC tem sido considerada uma das tecnologias mais promissoras para a geração de energia elétrica, com reduzido impacto ambiental ${ }^{(5)}$.

Dentre todos os condutores de íons oxigênio conhecidos, a zircônia estabilizada com ítria (YSZ) é o mais estudado e, em geral, sua condutividade iônica é considerada como padrão no estudo de novos materiais condutores.

\section{Sistema Zircônia-Escândia}

A zircônia estabilizada com escândia (ScSZ) apresenta alta condutividade para o íon oxigênio sendo cerca de 2,5 vezes superior à condutividade do YSZ ${ }^{(6,7,8)}$. A solução sólida de ScSZ apresenta baixa condutividade eletrônica e alta estabilidade química, quando comparada aos demais condutores de íons oxigênio. Devido a essas características, este sistema passou a ser estudado para aplicações que requerem alta condutividade iônica, sendo um candidato para aplicação como eletrólito sólido em SOFC para operação a temperaturas inferiores àquelas da zircônia-ítria, numa faixa denominada intermediária entre aproximadamente 600 e $800{ }^{\circ} \mathrm{C}^{(7,9)}$.

No entanto, uma das principais desvantagens da zircônia-escândia para este tipo de aplicação é sua relativa baixa estabilidade de fase ${ }^{(10-12)}$. No diagrama de fases do ScSZ, mostrado na Figura 2, várias fases foram identificadas: monoclínica $(m)$, tetragonal $(t)$, cúbica $(c)$ e três tipos de fase romboédrica com estequiometrias diferentes $\mathrm{Sc}_{2} \mathrm{Zr}_{7} \mathrm{O}_{17}(\beta), \mathrm{Sc}_{2} \mathrm{Zr}_{5} \mathrm{O}_{13}(\gamma)$ e $\mathrm{Sc}_{4} \mathrm{Zr}_{3} \mathrm{O}_{12}$ (ס) (11,12). Além dessas fases, dois tipos de fases tetragonal metaestáveis, denominadas $t^{\prime} \mathrm{e}$ $t^{\prime \prime}$, também foram reportadas ${ }^{(13,14)}$. A presença da fase $t^{\prime}$ é indesejável, uma vez que é responsável pela degradação da condutividade elétrica do ScSZ em condições de operação da célula a combustível ${ }^{(6,9,15,16)}$. 
Contudo, a estrutura do material é fortemente influenciada pelas condições de preparação das amostras, tratamento térmico e temperatura de investigação em que o material é submetido.

Enquanto que a fase cúbica do sistema ScSZ apresenta excelentes propriedades elétricas, as fases monoclínica e romboédrica possuem baixas condutividades elétricas. A maior parte dos trabalhos realizados com zircônia-escândia tem se concentrado numa faixa de composição molar de $\mathrm{Sc}_{2} \mathrm{O}_{3}$ entre aproximadamente 7 e 13\%, onde as fases cúbica, tetragonal e romboédrica ( $\beta$ ) são encontradas ${ }^{(9,14-17)}$.

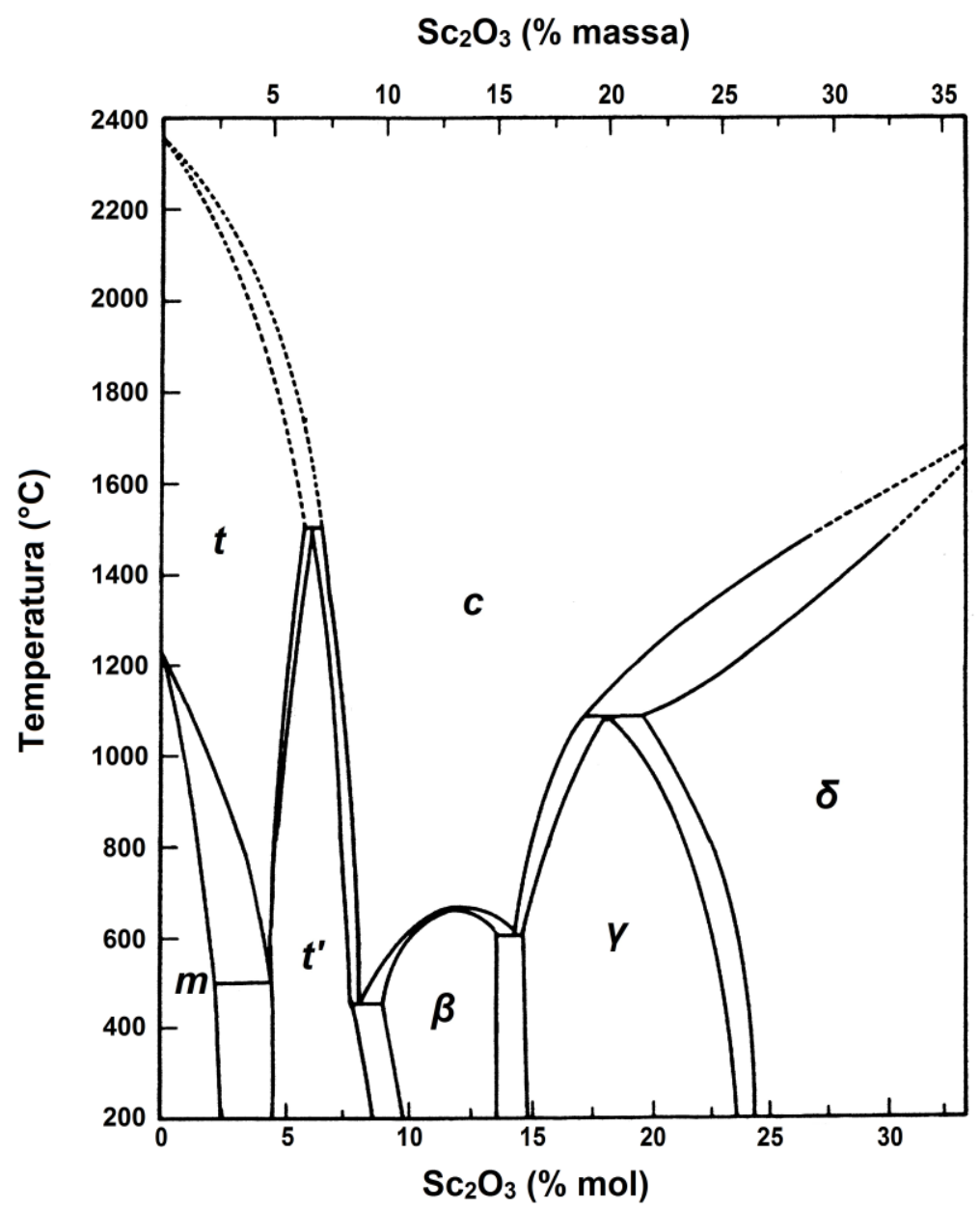

Figura 2. Diagrama de fases do sistema $\mathrm{ZrO}_{2}-\mathrm{Sc}_{2} \mathrm{O}_{3}{ }^{(11)}$. 
A Figura 3 mostra os difratogramas de raios $X$ das principais fases encontradas no sistema ScSZ. O número da ficha JCPDS está indicado para cada fase. É interessante notar que há grande semelhança entre os difratogramas de raios $X$ das fases cúbica e tetragonal no intervalo de $2 \theta$ entre 20 e $80^{\circ}$ (Figura 3a). Por outro lado, alguns picos de alta intensidade referentes à fase romboédrica, nas regiões de 30 e $50^{\circ}$, são bem característicos (10). As fases cúbica e tetragonal podem ser diferenciadas pelos formatos dos picos entre 73 e $76^{\circ}$ (Figura 3b).
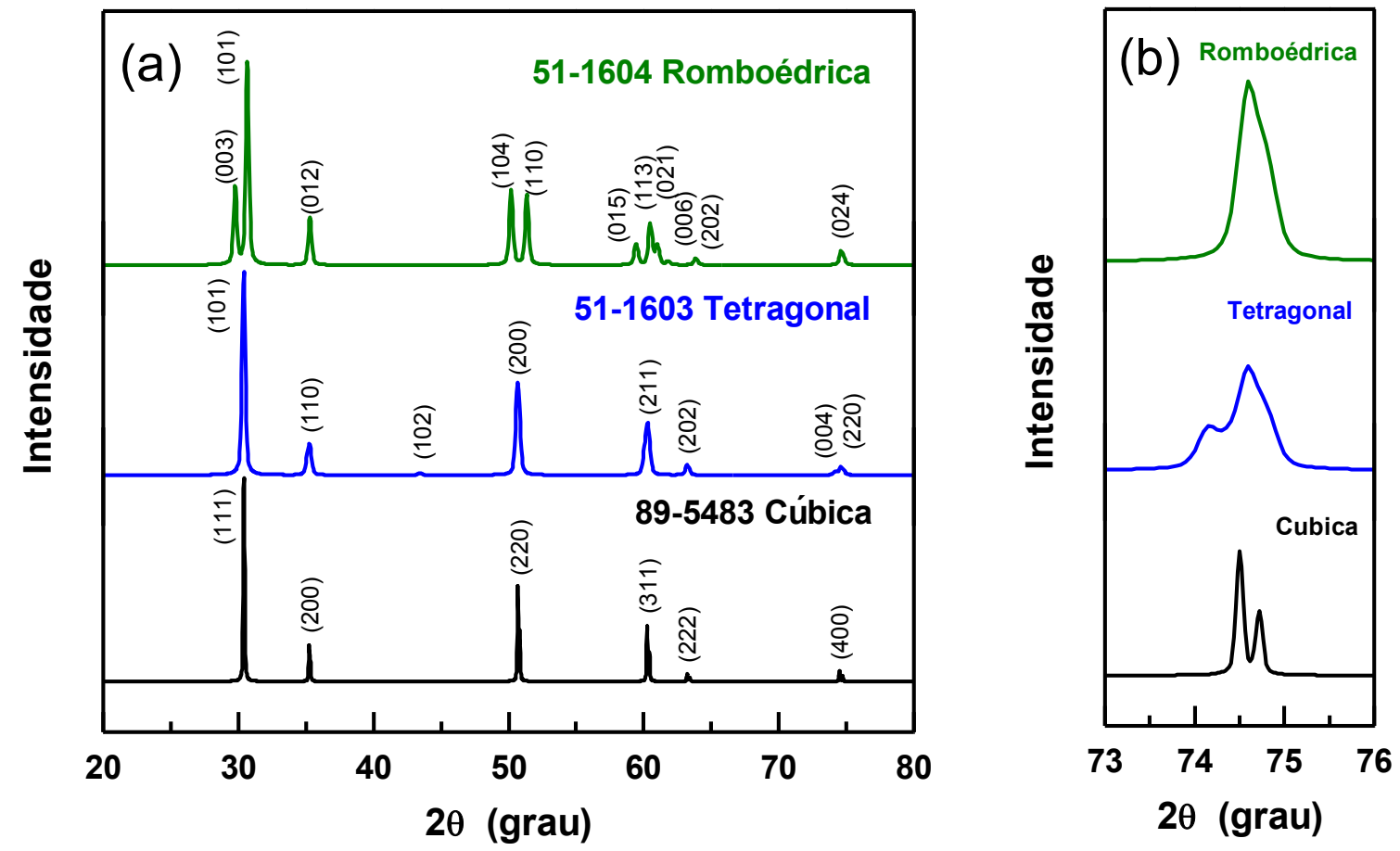

Figura 3. Difratogramas de raios $X$ das principais estruturas cristalinas encontradas para o sistema zircônia-escândia. Faixa de $2 \theta$ entre (a) 20 e $80^{\circ}$ e (b) 73 e $76^{\circ}$.

A representação da estrutura romboédrica $(\beta)$, obtida pelo programa Materials Studio ${ }^{\circledR}$, é mostrada na Figura 4. Essa estrutura é similar à estrutura cúbica, onde os parâmetros de rede $a, b$ e $c$ são iguais. A única diferença está num dos ângulos interaxiais, o qual é diferente de $90^{\circ}$. 


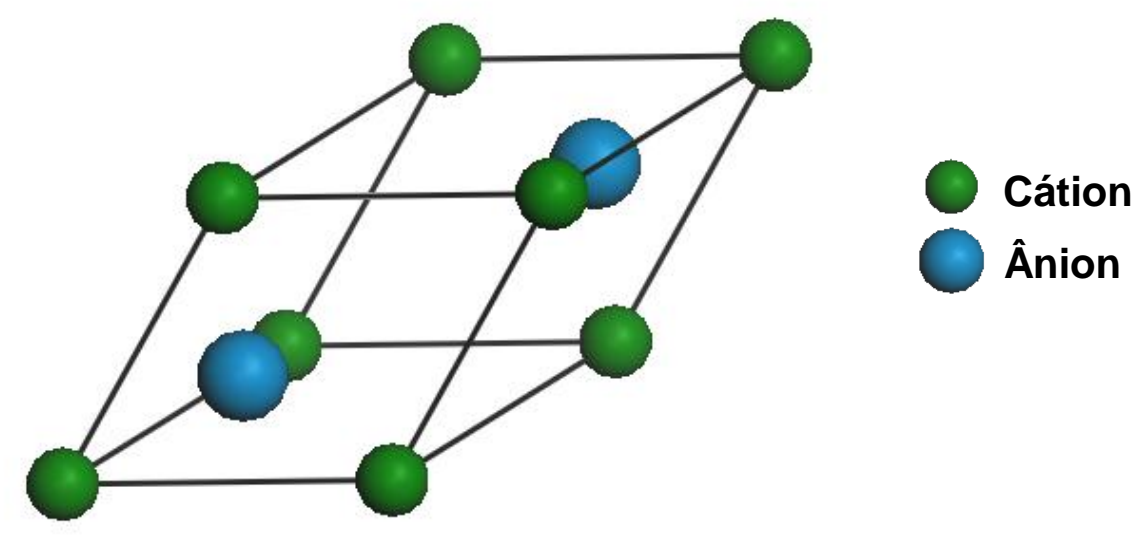

Figura 4. Estrutura romboédrica $(\beta)$ da zircônia-escândia.

De modo geral, na faixa de composição entre 5 e $7 \%$ em mol de $\mathrm{Sc}_{2} \mathrm{O}_{3}$, o material apresenta as fases cúbica e tetragonal. Os maiores valores de condutividade iônica são encontrados para composições próximas de $9 \%{ }^{(8)}$, na qual é possível obter a solução sólida com estrutura cúbica à temperatura ambiente ${ }^{(9)}$. No entanto, a degradação térmica (aging) é mais severa do que para composições mais ricas em escândia. A degradação térmica ocorre devido à formação da fase tetragonal na matriz cúbica ${ }^{(9,15,16)}$.

Por outro lado, para composições mais ricas em escândia, onde a fase $\beta$ é predominante, observa-se um salto da condutividade elétrica com o aumento da temperatura ${ }^{(8,9)}$, como pode ser observado no gráfico de Arrhenius para a condutividade para diferentes quantidades de $\mathrm{Sc}_{2} \mathrm{O}_{3}(7 ; 9,3 ; 10$ e $11 \%$ em mol) na Figura 5. Esse salto que ocorre entre aproximadamente 500 a $600{ }^{\circ} \mathrm{C}$ para composições de 10 a $13 \%$ é atribuído à transição de fase reversível cúbica $\leftrightarrow$ romboédrica ${ }^{(7,9,15,17)}$, a qual é acompanhada por uma variação no coeficiente de dilatação térmica do material ${ }^{(6)}$. 


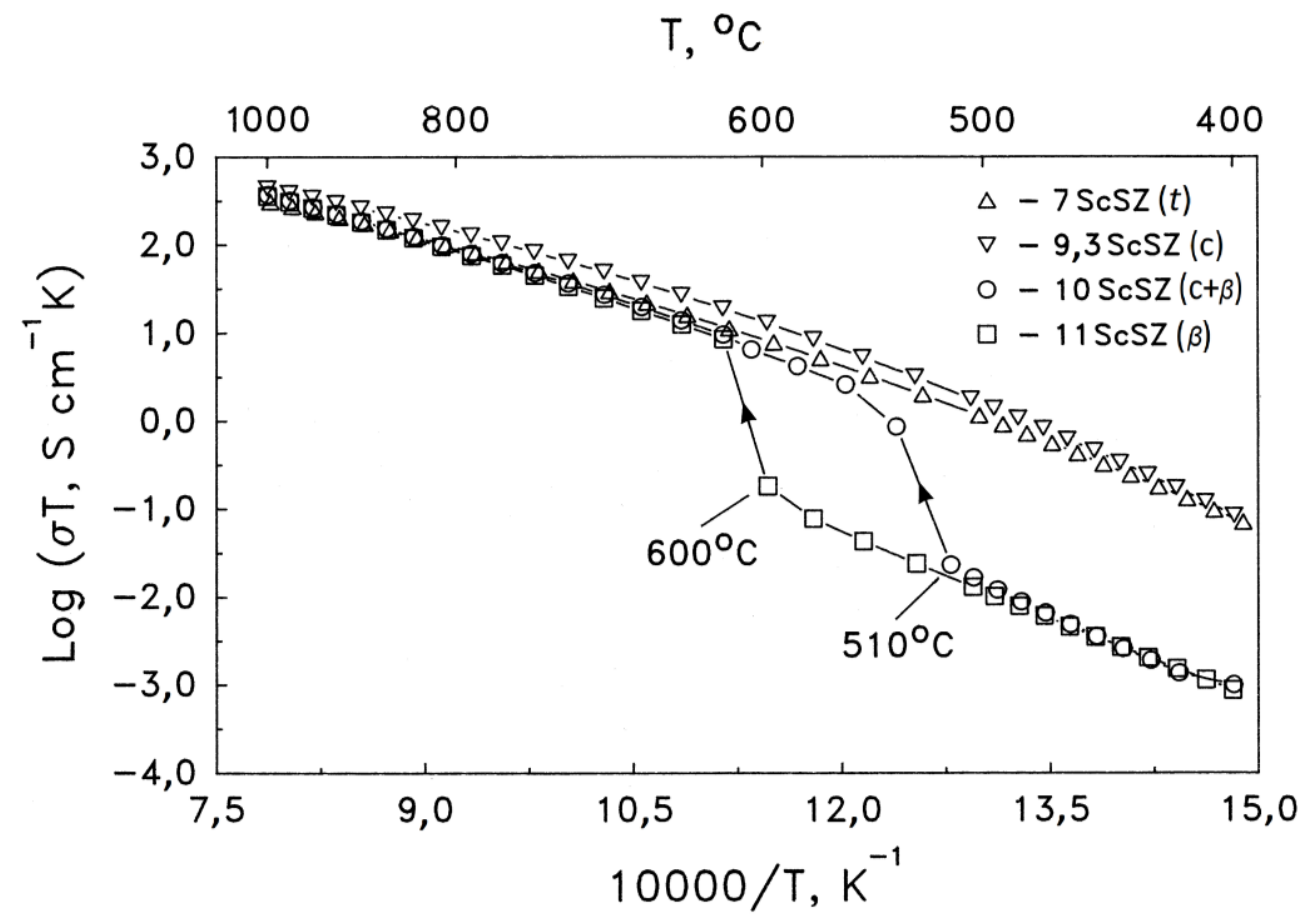

Figura 5. Gráfico de Arrhenius para a condutividade elétrica das principais estruturas encontradas na zircônia-escândia ${ }^{(9)}$.

Dessa forma, embora a zircônia-escândia apresente elevada condutividade elétrica, há uma limitação para a utilização deste sistema como eletrólito sólido. Se por um lado, baixas concentrações de escândia $(<10 \%$ em mol) promovem a degradação da condutividade o que diminuiria a eficiência e o tempo de vida útil da SOFC, a maior quantidade (10 a 13\% em mol) reduziria a estabilidade da célula a combustível devido à dilatação do material provocada pela transição de fase.

Recentemente, Okamoto e colaboradores ${ }^{(18)}$ demonstraram que é possível obter o material cúbico mesmo em composições mais elevadas de $\mathrm{Sc}_{2} \mathrm{O}_{3}$ (12\% em mol). Através da sinterização assistida por campo elétrico (Spark Plasma Sintering, SPS) ${ }^{(19,20)}$, os autores obtiveram a fase cúbica em amostras densas de ScSZ, onde foi possível eliminar a descontinuidade da condutividade elétrica. Posteriormente, Lei e Zhu ${ }^{(21)}$, também obtiveram a fase cúbica na zircônia contendo $11 \%$ em mol de escândia (11ScSZ) em amostras com tamanho médio de grãos nanométrico $(80 \mathrm{~nm})$. 
No entanto, ainda há grande dificuldade de se obter a fase cúbica no ScSZ com elevada estabilidade. Em composições mais elevadas de $\mathrm{Sc}_{2} \mathrm{O}_{3}$, essa fase foi obtida apenas em condições muito específicas. Dessa forma, a transformação de fase reversível cúbica $\leftrightarrow$ romboédrica e a estabilidade de fase dependem da composição dos óxidos constituintes, bem como do processamento empregado.

\section{Sistema Zircônia-Escândia-Céria}

Com a finalidade de melhorar a estabilidade de fases da zircônia-escândia, diferentes adições de óxidos metálicos têm sido propostas, como: $\mathrm{CeO}_{2}{ }^{(22)}$, $\mathrm{Y}_{2} \mathrm{O}_{3}{ }^{(23)}, \mathrm{Yb}_{2} \mathrm{O}_{3}{ }^{(7)}, \mathrm{Al}_{2} \mathrm{O}_{3}{ }^{(24)}, \mathrm{HfO}_{2}{ }^{(22)}, \mathrm{Mn}_{2} \mathrm{O}_{3}{ }^{(25)}, \mathrm{Ga}_{2} \mathrm{O}_{3}{ }^{(22)}$, sendo que a adição de céria tem apresentado resultados mais interessantes. Embora a adição de $\mathrm{CeO}_{2}$ promova uma diminuição da condutividade iônica do $\mathrm{ScSZ}\left(\mathrm{Sc}_{2} \mathrm{O}_{3}\right.$ entre 9 e $11 \%$ em mol), a condutividade da zircônia-escândia-céria (ScCeSZ) apresenta-se superior à do YSZ em temperaturas intermediárias ${ }^{(26)}$. Além disso, alguns trabalhos demonstraram que a adição de céria à zircônia-escândia promove a estabilização da fase cúbica, sendo que nenhuma transformação de fase entre 500 e $600{ }^{\circ} \mathrm{C}$, típica entre as fases cúbica e romboédrica, tem sido observada ${ }^{(22,27)}$.

Em 2003, Yamaji e colaboradores ${ }^{(28)}$ testaram o uso da ScCeSZ em células a combustível, tanto como eletrólito sólido como ânodo (Ni-ScCeSZ). A sinterização simultânea de substratos de Ni-ScCeSZ com filmes de ScCeSZ a $1200{ }^{\circ} \mathrm{C}$ produziu um eletrólito denso com boa estabilidade química em diferentes pressões parciais de oxigênio.

Em 2005, Wang e colaboradores ${ }^{(29)}$ realizaram estudos estruturais no 10ScSZ contendo diferentes quantidades de céria (1, 5 e $10 \%$ em mol). As soluções sólidas foram sintetizadas por coprecipitação e os estudos estruturais foram feitos por espectroscopia Raman e difração de raios $X$. Por difração de raios $\mathrm{X}$ obtiveram resultados bastante similares, mas os picos de difração apresentaram pequenas diferenças sugerindo uma composição de fases. Por espectroscopia Raman identificaram a fase tetragonal $t^{\prime}$ ao nível de traço. 
As bandas associadas a esta fase tiveram intensidade reduzida com aumento do teor de $\mathrm{CeO}_{2}$. Assim, concluíram que a adição de céria favorece a estabilização da fase cúbica, mas a fase $t^{\prime}$ ainda permanece até $10 \% \mathrm{em}$ mol de céria. Valores de condutividade iônica para as composições estudadas foram: 0,084 (1\%), 0,060 (5\%) e 0,049 (10\%) S.cm ${ }^{-1}$ a $800{ }^{\circ} \mathrm{C}$.

Lee e colaboradores ${ }^{(30)}$ mostraram que a condutividade iônica da zircônia contendo $10 \%$ em mol de escândia e $1 \%$ em mol de céria (10Sc1CeSZ) apresenta excelente estabilidade a $800{ }^{\circ} \mathrm{C}$ num período de tempo superior a $600 \mathrm{~h}$. A Figura 6 mostra as curvas de condutividade elétrica em função do tempo para a zircônia-escândia (contendo 7,8 e $8 \%$ em mol de $\mathrm{Sc}_{2} \mathrm{O}_{3}$ ) a $1000{ }^{\circ} \mathrm{C}$ e zircônia-escândia-céria a 800 e $1000^{\circ} \mathrm{C}$. Enquanto que, a condutividade elétrica do $10 \mathrm{Sc} 1 \mathrm{CeSZ}$ apresenta excelente estabilidade em temperaturas consideradas intermediárias e altas, há degradação significativa da condutividade do ScSZ em alta temperatura.

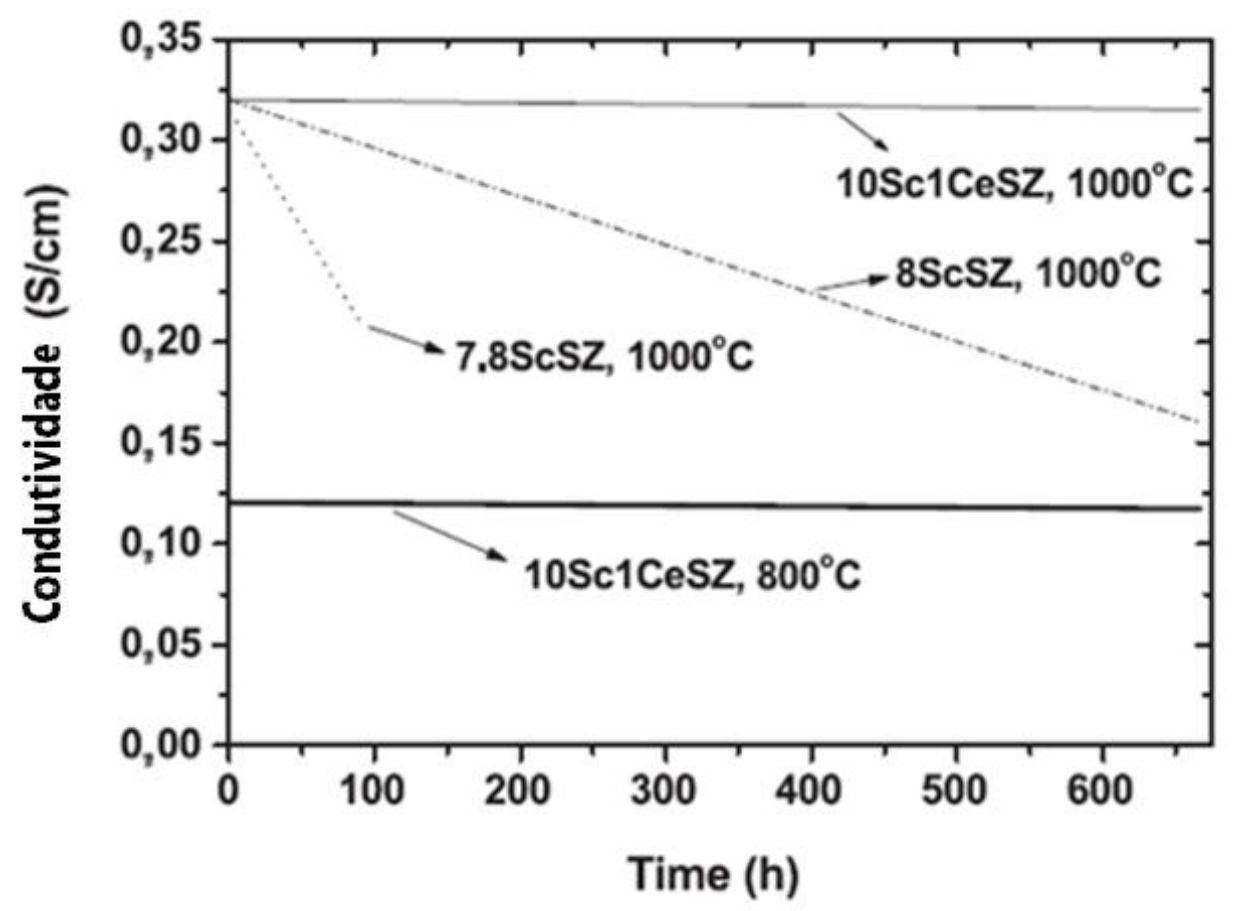

Figura 6. Condutividade elétrica em função do tempo para o ScSZ e 10Sc1CeSZ ${ }^{(30)}$. 
Além desse trabalho, outros estudos de envelhecimento térmico realizados a $600{ }^{\circ} \mathrm{C}$ no $10 \mathrm{Sc} 1 \mathrm{CeSZ}{ }^{(31,32)}$ demonstraram que a degradação da condutividade em atmosfera de ar é de aproximadamente $6 \%$ somente após $3000 \mathrm{~h}$. Por outro lado, em atmosfera redutora (mistura gasosa na proporção volumétrica de $9 \% \mathrm{H}_{2}, 1 \% \mathrm{H}_{2} \mathrm{O}$ e $90 \% \mathrm{~N}_{2}$ ), a degradação chega a $20 \%$. De acordo com os autores, a degradação da condutividade elétrica é atribuída à redução de cátions $\mathrm{Ce}^{4+}$ para $\mathrm{Ce}^{3+}$, a qual gera uma deformação elástica na rede cristalina do material. De outro modo, a degradação também tem sido interpretada como decorrente da associação ou formação de clusters de vacâncias de oxigênio ${ }^{(33)}$. A partir da caracterização estrutural por difração de raios $X$ observou-se que a estrutura cúbica foi mantida após análises de envelhecimento.

Portanto, embora a fase $t^{\prime}$, a qual é considerada responsável pela degradação da condutividade elétrica da zircônia-escândia ${ }^{(9,15,16)}$, tenha sido encontrada no $10 \mathrm{Sc} 1 \mathrm{CeSZ}{ }^{(29)}$, a condutividade apresenta excelente estabilidade por longo período de tempo ${ }^{(30-32)}$. Isso demonstra que o $10 \mathrm{Sc1CeSZ}$ apresenta-se como um forte candidato para aplicação como eletrólito em SOFC de temperaturas intermediárias.

Atualmente, as SOFC comercializadas utilizam zircônia-ítria como eletrólito sólido e necessitam atingir altas temperaturas, em torno de $1000^{\circ} \mathrm{C}$, para se obter a elevada condutividade elétrica do eletrólito (aproximadamente $\left.0,1 \mathrm{~S} . \mathrm{cm}^{-1}\right)^{(3,26)}$. As altas temperaturas provocam muitos efeitos indesejáveis na célula a combustível comprometendo seu desempenho, principalmente, devido à degradação de seus componentes e reações interfaciais. Dessa forma, a redução da temperatura de operação das SOFC tem sido o foco principal de muitos estudos para aumentar o tempo de vida útil de seus componentes e tornar o sistema mais estável, sem perder a eficiência. Além disso, a redução na temperatura de operação deve permitir o uso de materiais de menor custo. 
Diversos métodos de síntese têm sido empregados na preparação do 10Sc1CeSZ. Dentre os principais, pode-se destacar: coprecipitação ${ }^{(27)}$ realizada pela empresa japonesa Daiichi Kigenso Kagaku Kogyo (DKKK) ${ }^{(34)}$, spray pirólise pela empresa americana Praxair Surface Technologies (34), tape cast ${ }^{(35)}$, flame spray ${ }^{(36)}$, citrato ${ }^{(37)}$ e mistura de óxidos ${ }^{(31)}$. Isso mostra que o $10 \mathrm{Sc} 1 \mathrm{CeSZ}$ pode ser facilmente sintetizado. De acordo com os trabalhos da literatura, com exceção do material produzido pela empresa DKKK, a fase cúbica tem sido obtida à temperatura ambiente a partir dos métodos de síntese mencionados.

Yarmolenko e colaboradores ${ }^{(34)}$ analisaram o 10Sc1CeSZ comercializado pelas empresas DKKK e Praxair. Apenas o material produzido pela empresa DKKK apresentou uma composição de fases com pequena quantidade de fase romboédrica na matriz cúbica à temperatura ambiente. Estudos de difração de raios $\mathrm{X}$ em alta temperatura e calorimetria exploratória diferencial evidenciaram que 0 aumento da temperatura promoveu 0 desaparecimento gradual da fase secundária até $300{ }^{\circ} \mathrm{C}$ no material da DKKK. Nas temperaturas próximas a $400{ }^{\circ} \mathrm{C}$ ocorreu a transição de fase reversível cúbica $\leftrightarrow$ romboédrica, onde o material tornou-se completamente romboédrico entre 350 e $500{ }^{\circ} \mathrm{C}$, transformando-se novamente em cúbico a partir de $500^{\circ} \mathrm{C}$. A fase cúbica foi estabilizada à temperatura ambiente somente após sinterização a partir de $1300^{\circ} \mathrm{C}$. No entanto, a transição de fase ainda foi observada em amostras sinterizadas. Por outro lado, o material da Praxair apresentou-se cúbico monofásico em todo o intervalo de temperatura investigado.

Heel e colaboradores ${ }^{(36)}$ sintetizaram quimicamente o $10 \mathrm{Sc} 1 \mathrm{CeSZ}$ por flame spray e obtiveram amostras densas com densidades relativas de $94 \%$ somente após sinterização a $1550^{\circ} \mathrm{C}$ por $2 \mathrm{~h}$.

As pastilhas de $10 \mathrm{Sc} 1 \mathrm{CeSZ}$, produzidas pela empresa alemã Kerafol $\mathrm{GmbH}$, são constituídas por grãos com tamanho médio de aproximadamente $5 \mu \mathrm{m}$ e densidade relativa em torno de $98 \%{ }^{(38)}$. De acordo com Laguna e colaboradores ${ }^{(38)}$, esse material pode vir a ser utilizado em eletrolisadores apresentando boa estabilidade. Altos valores de densidade de corrente foram obtidos a $700{ }^{\circ} \mathrm{C}$ empregando eletrodos de Pt. 
Alguns trabalhos que correlacionam sinterização e condutividade elétrica demonstraram que a adição de agentes de sinterização, como $\mathrm{Li}_{2} \mathrm{CO}_{3}$ e $\mathrm{Bi}_{2} \mathrm{O}_{3}$, pode diminuir a temperatura de sinterização do ScCeSZ em torno de $200{ }^{\circ} \mathrm{C}$ sem alteração significativa das propriedade elétricas ${ }^{(27,39)}$. Entretanto, o uso de agentes de sinterização pode provocar efeitos indesejados, tais como: formação de fases secundárias, segregação do aditivo nos contornos de grão e microtrincas, influenciando fortemente as propriedades do material.

\section{Sinterização}

A sinterização é uma das etapas mais importantes no processamento de materiais cerâmicos e metálicos por metalurgia do pó. No caso de materiais cerâmicos, é nesta etapa do processamento que as partículas já conformadas adquirem resistência mecânica e quase todas as suas propriedades finais. A sinterização é um processo termodinâmico no qual um sistema de partículas vem adquirir uma estrutura sólida, através da redução na área superficial específica levando o sistema, na maioria das vezes, à retração e consequentemente à densificação ${ }^{(40)}$.

No processo de sinterização, dependendo das fases envolvidas, destacam-se basicamente dois tipos de mecanismos: por reações no estado sólido ou por fase líquida. Para o material de interesse neste trabalho, o principal mecanismo de sinterização é por reações no estado sólido.

Para facilitar o entendimento do processo de sinterização, todos os modelos existentes para sua descrição costumam dividi-lo em três estágios, embora inexista, na prática, uma distinção clara entre esses estágios (40). A Figura 7 ilustra as etapas de desenvolvimento microestrutural durante o processo de sinterização por reação em estado sólido.

- Estágio inicial: rearranjo das partículas do pó e formação de uma ligação forte ou "pescoço" nos pontos de contato entre as partículas (Figura 7b). A densidade relativa aumenta até cerca de $5 \%$; 
- Estágio intermediário: o tamanho dos pontos de contato aumenta, a porosidade diminui de modo substancial e as partículas se aproximam levando à retração do material (Figura 7c). Os contornos de grão (e os grãos) são formados e crescem lentamente; a densidade relativa pode chegar a aproximadamente $92 \%$. O estágio termina quando os poros estão isolados;

- Estágio final: a porosidade residual poderá ser eliminada gradativamente, mas a migração dos contornos de grão aprisiona os poros em seu interior e estes se fecham e arredondam tornando mais difícil sua eliminação (Figura $7 d$ ). Este último estágio é caracterizado principalmente pelo crescimento dos grãos.

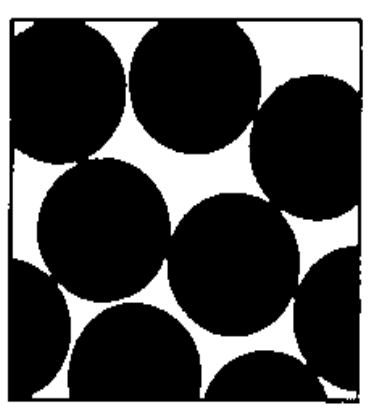

(a)

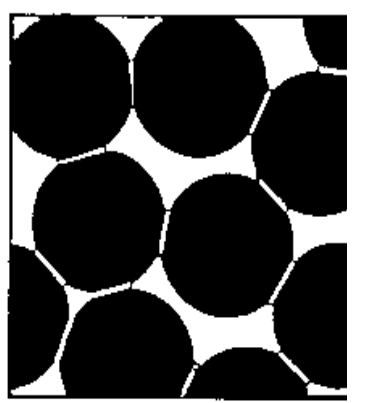

(b)

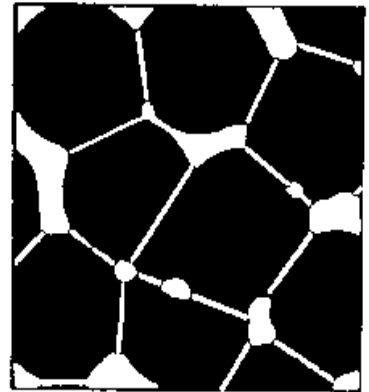

(c)

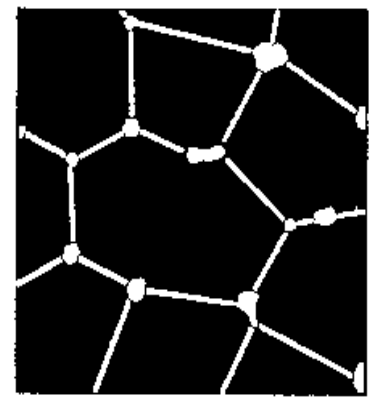

(d)

Figura 7. Representação esquemática do desenvolvimento da microestrutura durante a sinterização. (a) Partículas soltas de pó; estágios: (b) inicial, (c) intermediário e (d) final ${ }^{(40)}$.

Os principais parâmetros envolvidos na sinterização são: temperatura, tempo de patamar, taxas de aquecimento e resfriamento, atmosfera, tamanho médio inicial das partículas ou grânulos, área de superfície específica e coeficientes de difusão e concentração de defeitos reticulares (para os processos regidos por reações em estado sólido), dentre outros. Nem todos estes parâmetros são considerados pelos modelos existentes. Estudos recentes focalizaram a cinética de sinterização. Além dos estudos cinéticos, a evolução da microestrutura com a densificação é também importante ${ }^{(41,42)}$. 


\section{Algumas Técnicas de Sinterização}

Técnicas mais sofisticadas de sinterização como prensagem isostática a quente, sinterização com uso de microondas, sinterização rápida (fast firing) e sinterização assistida por campo elétrico podem ser úteis para melhorias em relação à densificação de materiais. Essas técnicas têm melhorado o processo de sinterização em relação ao processo convencional, devido à redução do tempo necessário para que haja uma efetiva densificação, e ainda podem promover uma diminuição significativa do tamanho dos grãos. No entanto, essas técnicas têm aplicação restrita, pois envolvem aumento no custo do processo de fabricação de materiais.

Recentemente foi proposta na literatura uma nova abordagem para a sinterização, na qual o aquecimento é realizado em forno convencional, mas o processo é dividido em duas etapas ${ }^{(43)}$.

A sinterização em duas etapas tem apresentado resultados interessantes em relação ao elevado grau de densificação e à redução do tamanho dos grãos. Neste trabalho é proposto verificar o efeito produzido pelo uso da nova técnica de sinterização em duas etapas no sistema zircônia-escândia-céria, bem como, pela sinterização pelo método convencional e assistida por campo elétrico.

\section{Sinterização em Duas Etapas}

A sinterização em duas etapas, proposta em 2000 por Chen e Wang ${ }^{(43)}$, tem como premissa a obtenção de cerâmicas densas e com tamanho de grãos reduzidos, porque suprime o crescimento de grãos que ocorre no estágio final de sinterização. Este método se baseia na densificação sem crescimento de grão no estágio final de sinterização. Assim, a amostra é inicialmente conduzida a uma alta temperatura por tempo quase nulo, sendo em seguida resfriada rapidamente até uma temperatura na qual permanece por um tempo específico.

Segundo os autores, a eficácia da densificação neste caso se deve à supressão da migração dos contornos de grão (responsável pelo crescimento dos grãos) ao mesmo tempo em que é mantida a difusão via contornos de grão (responsável pela eliminação da porosidade). Para que o processo seja otimizado os autores mostraram que uma densidade relativa em torno de $75 \%$ deve ser obtida na primeira etapa de sinterização. 
Posteriormente, alguns trabalhos foram publicados utilizando a sinterização em duas etapas para diversos materiais, sendo alguns deles descritos sucintamente a seguir.

Em trabalho posterior Lee e colaboradores ${ }^{(44)}$ mostraram que quando a sinterização se processa com formação de fase líquida a densificação no primeiro estágio deve ser mais alta, em torno de $85 \%$ da densidade teórica. Isto foi mostrado para a sinterização do $\mathrm{SiC}$ contendo $\mathrm{Y}_{2} \mathrm{O}_{3}$.

$\mathrm{Na}$ sinterização do $\mathrm{BaTiO}_{3}{ }^{(45)}$, apesar da alta densificação ter sido obtida, verificou-se que há pequeno crescimento dos grãos na segunda etapa de sinterização. Também foi feita a sinterização em duas etapas para o $\mathrm{Si}_{3} \mathrm{~N}_{4}$ na qual um material denso e sem fases secundárias foi obtido ${ }^{(46)}$.

O método de sinterização em duas etapas foi utilizado também no estudo da alumina ${ }^{(47)}$ e do $\mathrm{ZnO}{ }^{(48)}$. Nos dois casos houve sucesso com relação à obtenção de cerâmicas densas sem crescimento de grão no segundo estágio. Bodisová (47) mostrou também que a taxa de aquecimento influencia o crescimento de grão na segunda etapa de sinterização. Quanto menor for a taxa de aquecimento maior será o crescimento de grão. Por outro lado, Mazaheri ${ }^{(48)}$ mostrou a importância da escolha correta para as temperaturas nos diferentes estágios de sinterização.

Binner e colaboradores ${ }^{(49)}$ também tiveram sucesso no uso do método de duas etapas para a obtenção de cerâmicas de zircônia-ítria densas contendo grãos nanométricos. Esta última característica, entretanto, mostrou ser dependente dos materiais de partida. Além disso, os autores também observaram que há um crescimento de grão, ainda que limitado, no segundo estágio de sinterização.

Dessa forma, esse novo método demonstra ser bastante adequado para diversos tipos de materiais cerâmicos, independente do mecanismo predominante de sinterização. Até o presente momento, nenhum trabalho reportando a sinterização em duas etapas na zircônia-escândia e zircônia-escândia-céria foi encontrado. 
Sinterização Assistida por Campo Elétrico

Conforme mencionado anteriormente, a sinterização assistida por campo elétrico tem possibilitado melhorias nas propriedades da zircônia-escândia ${ }^{(18)}$. Alguns autores, a partir da sinterização por SPS, conseguiram obter amostras densas de ScSZ com tamanho médio de grãos na ordem de 0,3 $\mu$ m e estabilizar a fase cúbica, eliminando a descontinuidade da curva da condutividade elétrica $^{(18,50,51)}$. A sinterização por SPS pode promover a obtenção de grãos ainda menores, na ordem de $10 \mathrm{~nm}$, como foi obtido para materiais à base de zircônia e céria ${ }^{(19)}$. A utilização de materiais nanométricos pode promover melhorias em SOFC ${ }^{(52)}$. No entanto, assim como a sinterização em duas etapas, nenhum trabalho foi encontrado na literatura referente ao ScCeSZ sinterizado por SPS.

O processo de sinterização assistida por campo elétrico permite a utilização de temperaturas mais baixas e tempos muito menores (poucos minutos), comparado com a sinterização convencional, produzindo materiais densos com pequeno crescimento de grãos ${ }^{(19,20,53,54)}$.

A sinterização por SPS é similar à prensagem a quente. No caso de materiais metálicos 0 pó é prensado uniaxialmente em um molde, normalmente de grafita, e pulsos de baixa voltagem com elevadas correntes são aplicados diretamente no molde e no pó. O pó é aquecido pela descarga elétrica que passa entre as partículas e pela corrente através do molde, produzindo elevadas taxas de aquecimento (até $1000^{\circ} \mathrm{C} / \mathrm{min}$ ) ${ }^{(19,20)}$. Devido às descargas elétricas, as superfícies das partículas do pó são ativadas e um fenômeno de auto-aquecimento é gerado entre as partículas, fazendo com que a transferência de calor ocorra rapidamente ${ }^{(19,20)}$. O processo de SPS é caracterizado pela alta eficiência térmica devido ao aquecimento direto do molde de grafita e do pó a ser sinterizado pela passagem de altas correntes elétricas. A principal vantagem do processo SPS em relação aos processos convencionais de prensagem a quente e isostática a quente é o menor consumo energético, em torno de um terço a um quinto ${ }^{(20,53)}$. 
A Figura 8 mostra uma ilustração do sistema de SPS. A pressão é aplicada uniaxialmente na parte superior e inferior da amostra. Alguns sistemas de SPS podem atingir pressões de até $1 \mathrm{GPa}{ }^{(19,54)}$. Para manter o sistema isolado dos pulsos elétricos de corrente contínua que atravessam o molde de grafita é utilizada uma câmara a vácuo com refrigeração à água. Durante o processo de sinterização a temperatura pode ser acompanhada por um termopar ou um pirômetro.

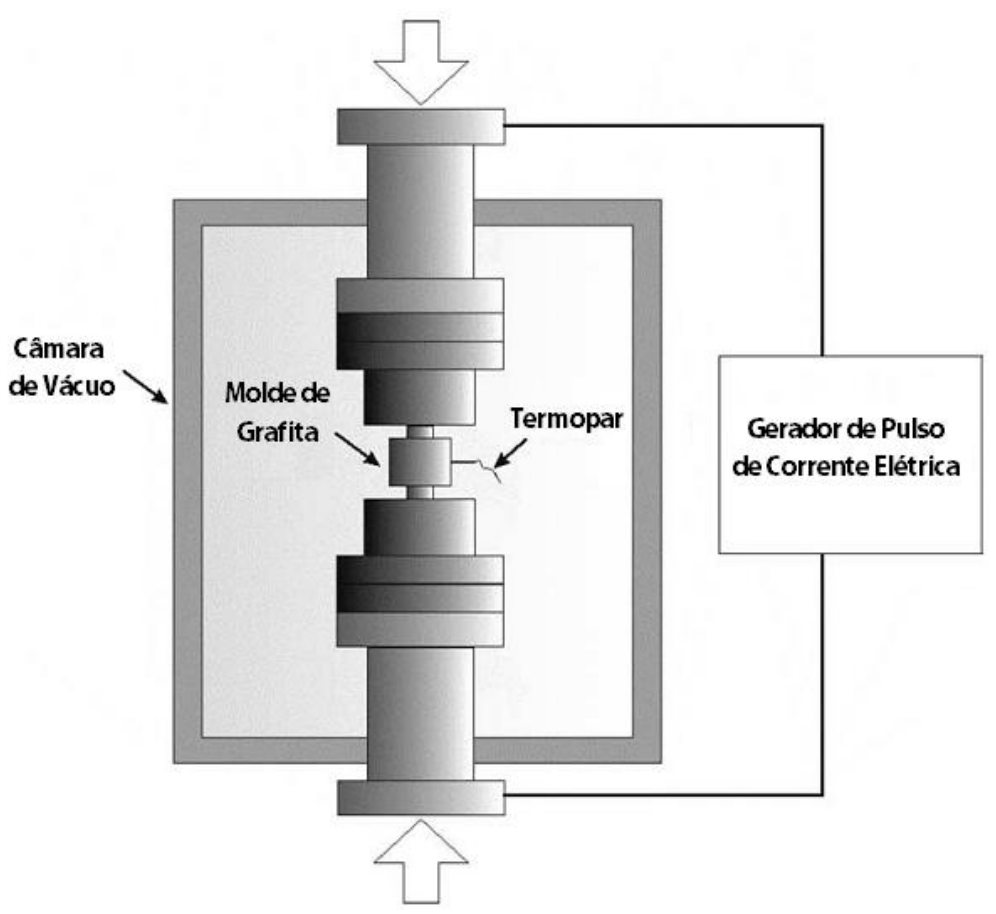

Figura 8. Ilustração da configuração do sistema de sinterização assistida por campo elétrico ${ }^{(19)}$.

A corrente elétrica aplicada ao molde é emitida pelo sistema de SPS em pulsos rápidos que podem ser ajustados entre 1 a $255 \mathrm{~ms}$ de duração. A tensão aplicada compreende valores entre 0 e $10 \mathrm{~V}$, enquanto a corrente pode chegar a $8.000 \mathrm{~A}^{(19,53)}$. Os pulsos elétricos são emitidos de forma consecutiva (pulso ON) seguidos pela ausência de pulsos (pulso OFF), onde cada pulso tem o mesmo tempo de duração. 
A Figura 9 mostra uma representação das descargas elétricas atravessando as partículas ${ }^{(20)}$. Os sucessivos pulsos elétricos promovem o aquecimento Joule (aquecimento de regiões específicas) em toda a superfície de cada partícula metálica. A pressão aplicada desempenha um importante papel no controle do crescimento de partículas influenciando na densidade do compacto. As elevadas pressões fazem com que a descarga elétrica e o aquecimento Joule sejam difundidos por toda a amostra, resultando em uma distribuição rápida de calor, alta homogeneidade e elevados graus de densificação.

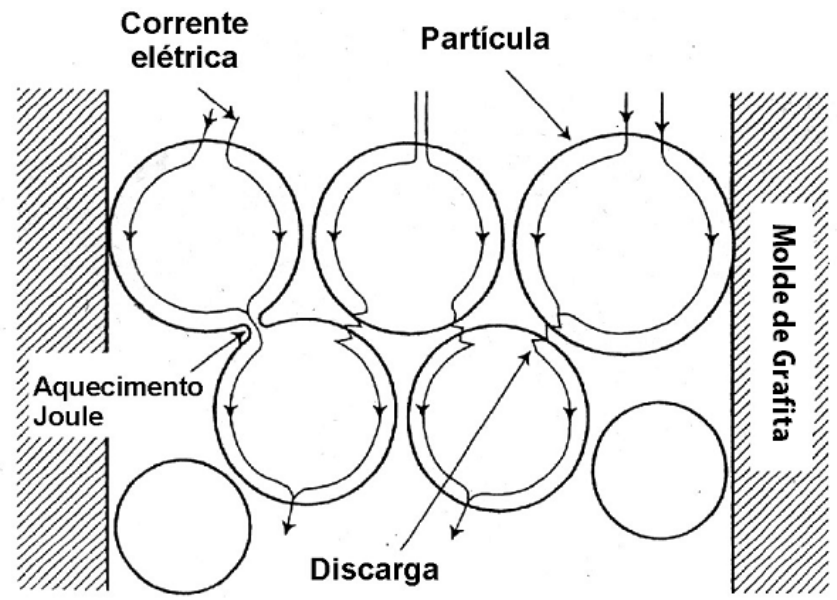

Figura 9. Representação do fluxo de corrente elétrica através das partículas ${ }^{(20)}$.

A rápida difusão da descarga elétrica e o consistente aquecimento em toda amostra produz pouco estresse interno, evitando microtrincas. Dessa forma, através da sinterização por SPS, as partículas são unidas de modo uniforme devido à energia fornecida pela descarga elétrica e pressão aplicada.

Convém salientar que esta descrição do método SPS é válida para partículas de materiais metálicos (materiais condutores). No caso de materiais cerâmicos (materiais isolantes), o aquecimento se dá, em princípio, pela transmissão de calor do molde para as partículas, como no método de prensagem a quente. 


\section{Objetivos}

O objetivo principal desse trabalho consiste no estudo do efeito da sinterização convencional, em duas etapas e assistida por campo elétrico na densificação, microestrutura e condutividade elétrica da zircônia-escândia-céria comercial visando à obtenção de cerâmicas densas em temperaturas relativamente baixas e com homogeneidade estrutural e microestrutural.

Os objetivos específicos são:

- Verificação de algumas variáveis no sucesso deste processo, tais como: temperaturas e tempos de patamar utilizados nas sinterizações;

- Análise da eficiência dos métodos de sinterização estudados na obtenção de cerâmicas densas e com tamanho de grãos reduzidos na zircônia-escândia-céria frente ao método convencional, levando em consideração as propriedades elétricas. 


\section{MATERIAIS E MÉTODOS}

Neste capítulo serão detalhados o material utilizado, a metodologia para a elaboração de corpos de prova e os métodos de caracterização.

\section{Material de Partida}

Como material de partida foi utilizada a zircônia-escândia-céria comercial (Fuel Cell Materials, ScCeSZ-TC, lote \# 315-034). De acordo com as informações fornecidas pelo fabricante este material possui $10 \%$ em mol de $\mathrm{Sc}_{2} \mathrm{O}_{3}$ e $1 \%$ em mol de $\mathrm{CeO}_{2}$, área de superfície específica igual a $11,5 \mathrm{~m}^{2} \cdot \mathrm{g}^{-1}$ e $99,98 \%$ de pureza e $0,34 \%$ de água fisicamente adsorvida. Este material foi utilizado como recebido.

\section{Elaboração dos Corpos de Prova}

Nesta seção serão descritos os procedimentos utilizados para a elaboração dos compactos utilizados para a sinterização pelos métodos convencional e de duas etapas, bem como, para a sinterização assistida por campo elétrico.

\section{Métodos Convencional e de Duas Etapas}

Amostras cilíndricas de $3 \mathrm{~mm}$ de espessura foram conformadas por prensagem uniaxial em matriz de aço inoxidável de diâmetro igual a $10 \mathrm{~mm}$, por meio da aplicação de pressão igual a $45 \mathrm{MPa}$, obtendo-se valores de densidade relativa a verde em torno de $40 \%$. Em seguida, foi feita compactação isostática a frio a $100 \mathrm{MPa}$. Após compactação, as amostras foram sinterizadas ao ar, em duplicata, em diferentes condições de temperatura e tempo de patamar, em forno resistivo tipo caixa (Lindberg modelo 51524, 1700C). 
A Figura 10 mostra os perfis temperatura-tempo para os processos de sinterização convencional (a) e em duas etapas (b). As amostras sinterizadas pelo método convencional (Figura 10a) foram aquecidas a uma determinada temperatura, na faixa de 1000 a $1500{ }^{\circ} \mathrm{C}$, com taxa de aquecimento de $10^{\circ} \mathrm{C} / \mathrm{min}$, sendo mantidas por um determinado período de tempo entre 0 e $15 \mathrm{~h}$.

Para o estudo de sinterização em duas etapas, as amostras foram sinterizadas em diferentes temperaturas $T_{1}$ e $T_{2}$ e diversos tempos $t_{2}$, com taxa de aquecimento igual a $10{ }^{\circ} \mathrm{C} / \mathrm{min}$. A taxa de resfriamento de $T_{1}$ para $T_{2}$ foi de $30{ }^{\circ} \mathrm{C} / \mathrm{min}$. $O$ tempo $t_{1}$ foi igual a zero, ou seja, assim que o forno atinge a temperatura $T_{1}$ inicia o resfriamento até $T_{2}$ onde permanece pelo tempo $t_{2}$, como pode ser observado na Figura 10b.
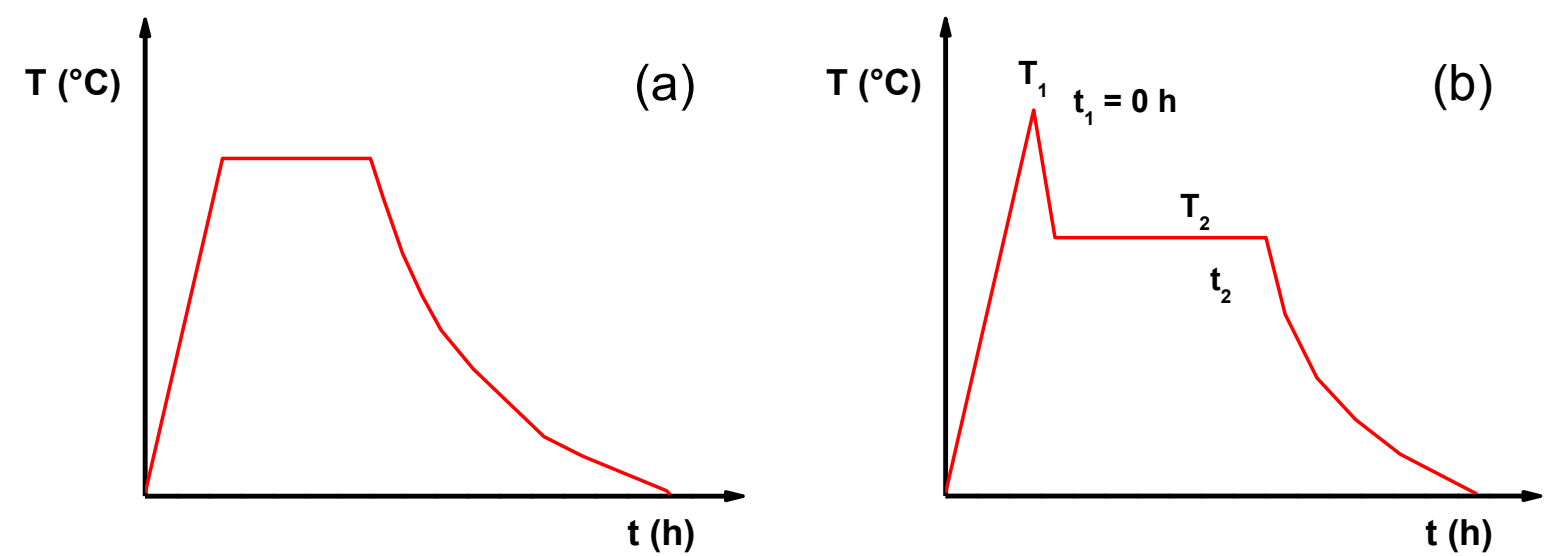

Figura 10. Representação do perfil temperatura-tempo nos processos de sinterização (a) convencional e (b) em duas etapas.

As amostras sinterizadas pelo método convencional e de duas etapas foram submetidas ao processo de resfriamento natural do forno. A Figura 11 mostra as temperaturas registradas pelo termopar tipo $B$ interno do forno durante o resfriamento em função do tempo. Dessa forma, é possível observar que, na região de altas temperaturas, acima de $1000^{\circ} \mathrm{C}$, o forno acompanha a taxa programada de $30{ }^{\circ} \mathrm{C} / \mathrm{min}$. No entanto, para temperaturas inferiores a $1000{ }^{\circ} \mathrm{C}$, o forno resfria mais lentamente do que o programado. 

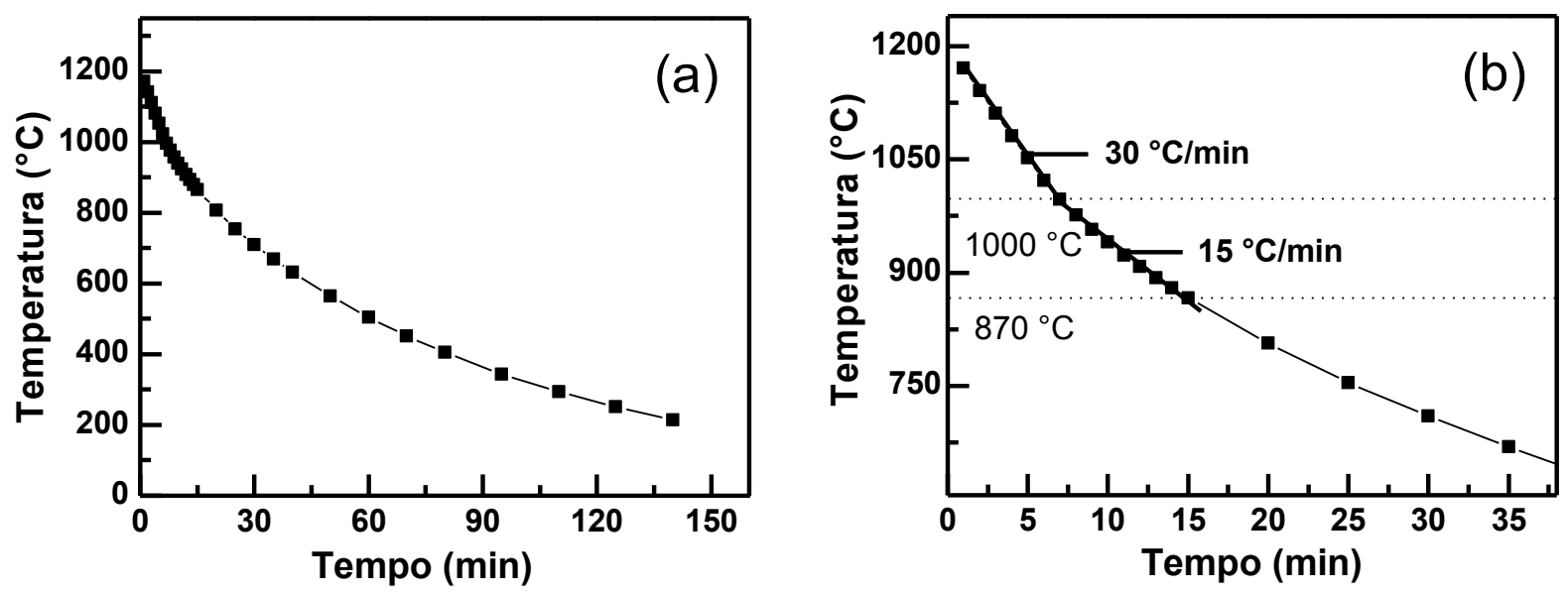

Figura 11. Temperaturas registradas durante o resfriamento do forno tipo caixa em função do tempo no intervalo entre (a) 0 e 150 min e (b) 0 e 35 min.

\section{Sinterização Assistida por Campo Elétrico}

A sinterização assistida por campo elétrico foi realizada em equipamento (SPS-1050, Syntex Inc.) do Departamento de Engenharia Mecatrônica da Escola Politécnica da USP. Os pós de zircônia-escândia-céria foram colocados em molde de grafita com diâmetro de $20 \mathrm{~mm}$. Uma folha de grafita (Perma Foil, PF40R2) foi utilizada nas paredes do molde e na interface entre os punções e o pó para proteger o molde da possível difusão de espécies químicas e facilitar a extração da amostra após tratamento térmico. A Figura 12 ilustra um corte vertical do conjunto: molde-amostra-punção.

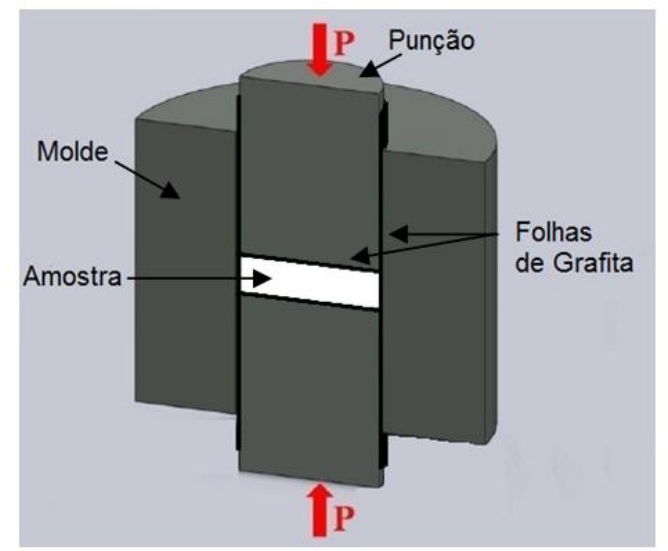

Figura 12. Ilustração de corte vertical do conjunto utilizado na sinterização assistida por campo elétrico ${ }^{(55)}$. 
Num experimento típico o material na forma de pó é colocado sobre o punção inferior (protegido pela folha de grafita). Após a colocação da segunda folha de grafita, sobre o material, é introduzido o punção superior. O conjunto é introduzido numa câmara selada e feito vácuo $(<20 \mathrm{~Pa})$, onde são monitorados: a pressão aplicada ao molde, a temperatura, o deslocamento e a taxa de deslocamento do punção. $O$ monitoramento da temperatura durante o processo de sinterização foi realizado com o auxílio de um pirômetro óptico (CHINO), o qual registra o valor da temperatura da parede externa do molde. A Figura 13 mostra, como exemplo, um gráfico típico dos parâmetros fornecidos pelo equipamento. Inicialmente, o sistema é aquecido a aproximadamente $600{ }^{\circ} \mathrm{C}$, temperatura mínima que o pirômetro consegue registrar, e mantido por alguns minutos para garantir que todos os componentes permaneçam nessa temperatura. Em seguida, o sistema é aquecido rapidamente até o patamar, onde é mantido por poucos minutos, enquanto que, a pressão aplicada aumenta durante o aquecimento e se mantém constante durante o patamar.

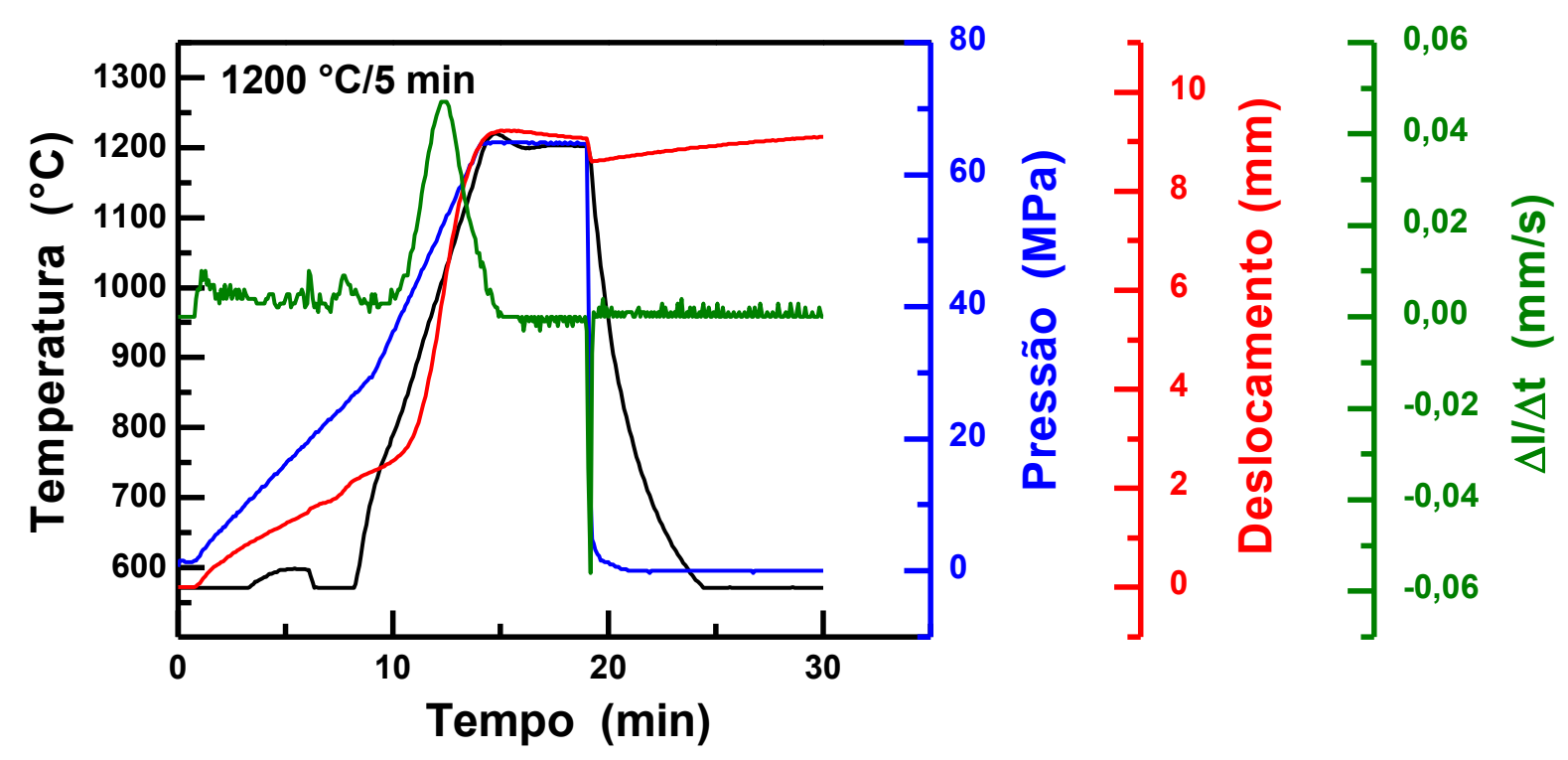

Figura 13. Parâmetros registrados pelo equipamento de SPS durante a sinterização a $1200^{\circ} \mathrm{C}$ por 5 min. 
As amostras foram sinterizadas na forma de discos, de aproximadamente $5 \mathrm{~mm}$ de espessura, nas temperaturas de 1000,1100 e $1200{ }^{\circ} \mathrm{C}$ com taxa de aquecimento de $100{ }^{\circ} \mathrm{C} / \mathrm{min}$ e com aplicação de pressão uniaxial de $65 \mathrm{MPa}$ no patamar. Os tempos de patamar estudados neste trabalho foram de 1 e $5 \mathrm{~min}$. O resfriamento foi realizado com taxa de $300^{\circ} \mathrm{C} / \mathrm{min}$ sem aplicação de pressão.

As amostras sinterizadas por SPS foram cortadas para serem caracterizadas. A ilustração dos cortes realizados é mostrada na Figura 14. Inicialmente, foram realizados dois cortes principais $A$ e $A^{\prime}\left(\overline{A A^{\prime}} \approx 5 \mathrm{~mm}\right)$. Em seguida, as amostras foram seccionadas em fatias $B$ e $B^{\prime}\left(\overline{B^{\prime}} \approx 2 \mathrm{~mm}\right)$. As análises foram feitas nas partes internas, indicadas pelas setas.

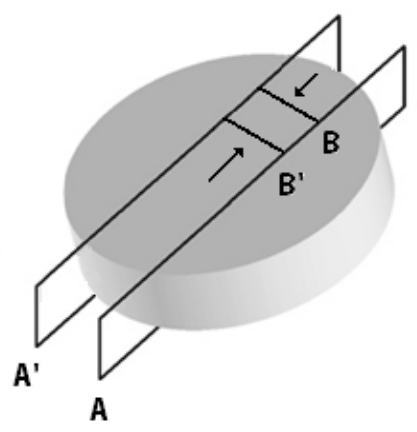

Figura 14. llustração do esquema de corte em amostras sinterizadas por SPS ${ }^{(56)}$.

\section{Caracterização das Amostras}

A caracterização estrutural do material como recebido e após tratamentos térmicos foi feita por difração de raios X, DRX (Bruker-AXS, D8 Advance) utilizando a radiação $\mathrm{K}_{\alpha}$ do $\mathrm{Cu}(\lambda=1,5405 \AA)$ e filtro de $\mathrm{Ni}$, na faixa angular de $2 \theta$ entre 20 e $80^{\circ}$, com passo de $0,05^{\circ}$ e tempo de exposição de $2 \mathrm{~s}$. A identificação dos picos de difração foi feita com auxílio das fichas JCPDS 89-5483 e 51-1604 da zircônia-escândia para as fases cúbica e romboédrica, respectivamente.

Foi feita também no material de partida a caracterização térmica por meio da análise termogravimétrica e térmica diferencial simultânea (STA409, Netzsch). As medidas foram realizadas a partir da temperatura ambiente até $1000{ }^{\circ} \mathrm{C}$ com taxa de aquecimento e resfriamento de $10{ }^{\circ} \mathrm{C} / \mathrm{min}$, em atmosfera de ar sintético ( $5 \mathrm{~mL} / \mathrm{min}$ ), utilizando-se $\alpha$-alumina como material de referência. 
A análise da retração linear do compacto a verde foi realizada em dilatômetro (Setaram, modelo Labsys) do Centro de Células a Combustível e Hidrogênio (CCCH/IPEN). Amostras cilíndricas foram compactadas uniaxialmente em matriz de aço inoxidável de diâmetro igual a $5 \mathrm{~mm}$ com aplicação de pressão de $50 \mathrm{MPa}$, seguido de compactação isostática a frio (210 MPa), obtendo-se amostras com densidades relativas a verde em torno de $45 \%$. As medidas de dilatometria foram realizadas a partir da temperatura ambiente até $1380{ }^{\circ} \mathrm{C}$ com taxa de aquecimento de $10^{\circ} \mathrm{C} / \mathrm{min}$ e resfriamento de $20^{\circ} \mathrm{C} / \mathrm{min}$, em atmosfera estática de ar sintético.

A densidade aparente das amostras sinterizadas foi determinada por meio dos métodos geométrico e de imersão em água, utilizando o princípio de Arquimedes, e comparada com a densidade teórica do ScCeSZ $\left(5,90 \mathrm{~g} / \mathrm{cm}^{3}\right)$. O método de imersão foi utilizado apenas em amostras com densidade geométrica relativa maior que $85 \%$. Para o método geométrico, as dimensões das amostras foram determinadas por micrômetro da marca Tesa. Foram feitas 10 medidas de diâmetro e 10 de espessura, para obter precisão adequada neste tipo de medida. A massa foi determinada em balança analítica (Mettler, H315), a qual foi também utilizada para o método de imersão, onde foram realizadas 10 determinações de massa imersa, úmida e seca.

Para a caracterização microestrutural, o pó e amostras sinterizadas selecionadas foram analisadas por microscopia eletrônica de varredura, MEV (Philips, $\mathrm{XL30}$ ) e a microanálise foi realizada por espectroscopia de raios $\mathrm{X}$ por dispersão de energia (EDS). As amostras sinterizadas foram seccionadas por disco adiamantado em cortadeira IsoMet (Buehler), embutidas, lixadas e polidas com pastas adiamantadas com granulações de 15, 6 e $1 \mu \mathrm{m}$ (MetaDi, Buehler). A revelação dos contornos de grão ocorreu por meio de ataque térmico a $100{ }^{\circ} \mathrm{C}$ abaixo da temperatura de sinterização. Para as amostras sinterizadas pelo método de duas etapas, realizou-se ataque térmico a $100{ }^{\circ} \mathrm{C}$ abaixo da temperatura $\mathrm{T}_{2}$. A observação das amostras sinterizadas por SPS e de fratura de amostras com densidade relativa igual ou inferior a $75 \%$ foi realizada por microscópio eletrônico de varredura com fonte de emissão eletrostática, FEG (Jeol, JSM 6701F). O tamanho médio de grãos foi determinado pelo método dos interceptos (método de Mendelson) ${ }^{(57)}$ numa amostragem superior a 500 grãos. 
A condutividade elétrica foi determinada por meio da técnica de espectroscopia de impedância. As medidas foram realizadas no intervalo de frequência de $5 \mathrm{~Hz}$ a $13 \mathrm{MHz}$ na faixa de temperatura entre 300 e $450^{\circ} \mathrm{C}$, com uma tensão aplicada de $100 \mathrm{mV}$, utilizando-se um analisador de impedância HP 4192A, acoplado a um computador HP 362 . O porta-amostras de inconel permite a realização de medidas em três amostras em cada experimento. Para a realização das medidas em função da temperatura, o porta-amostra é inserido num forno tubular (EDG). A temperatura foi monitorada com termopar tipo $\mathrm{K}$ (Cromel/Alumel) posicionado próximo às amostras. Para as medidas elétricas realizou-se a deposição dos eletrodos em faces opostas das amostras com aplicação de tinta de prata (Cerdec) seguida de cura da resina a $400{ }^{\circ} \mathrm{C}$. Nas amostras sinterizadas por SPS, os eletrodos foram depositados em amostras segmentadas nas regiões indicadas pelas setas na Figura 14. Os dados das medidas elétricas foram coletados e analisados por meio de programa computacional ${ }^{(58)}$.

O fluxograma das etapas de caracterização do pó e das amostras sinterizadas pelos métodos convencional e de duas etapas é mostrado na Figura 15. Após a caracterização do pó, foi realizada análise da retração linear e sinterização em forno tipo caixa, seguida pela análise de fases e microestrutural e determinação da condutividade elétrica de amostras densas.

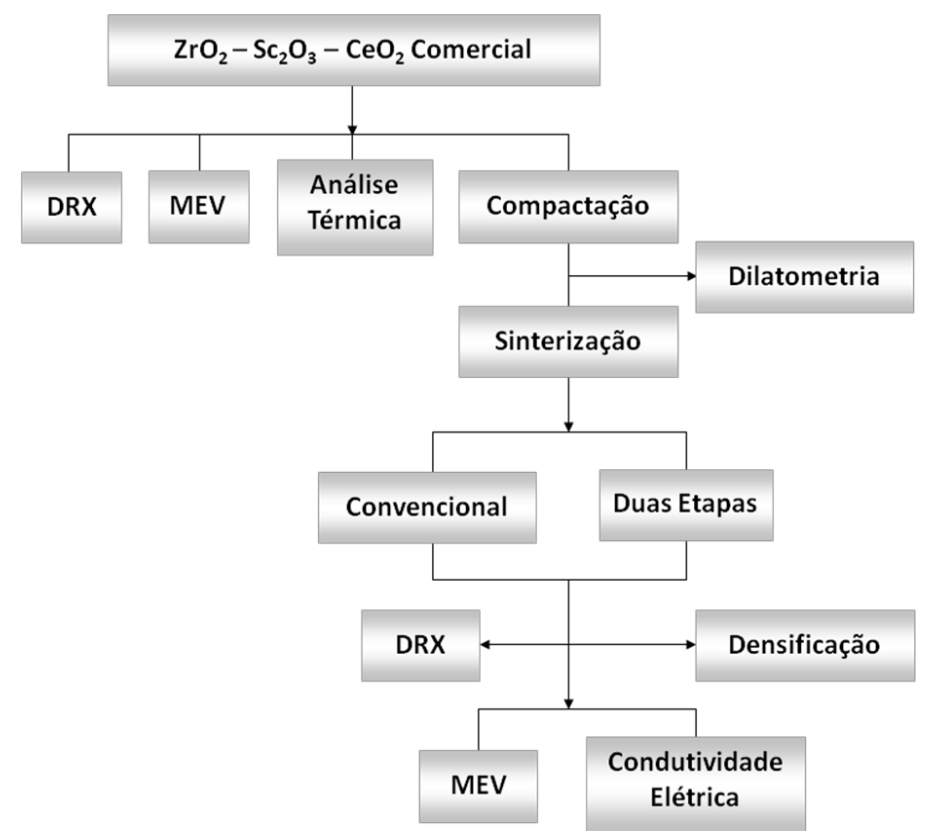

Figura 15. Fluxograma das etapas de caracterização do pó e das amostras sinterizadas pelos métodos convencional e de duas etapas. 
O fluxograma do processo de caracterização das amostras sinterizadas por SPS é mostrado na Figura 16. Inicialmente, realizou-se o estudo da densificação das amostras através dos métodos geométrico e hidrostático. Em seguida, as amostras foram segmentadas e caracterizadas. A análise de fases foi realizada por difração de raios X e por espectroscopia Raman do Instituto de Química da USP. Os espectros Raman na região do ultravioleta (UV) próximo foram obtidos através de fonte laser de He-Ne com $\lambda=633 \mathrm{~nm}$ no intervalo de 200 a $800 \mathrm{~cm}^{-1}$. A caracterização microestrutural de amostras polidas e atacadas termicamente foi feita por FEG. Algumas amostras foram tratadas termicamente a $900{ }^{\circ} \mathrm{C}$ por $4 \mathrm{~h}$ para avaliar a possibilidade de eliminação de carbono. A caracterização destas amostras foi feita por difração de raios $X$.

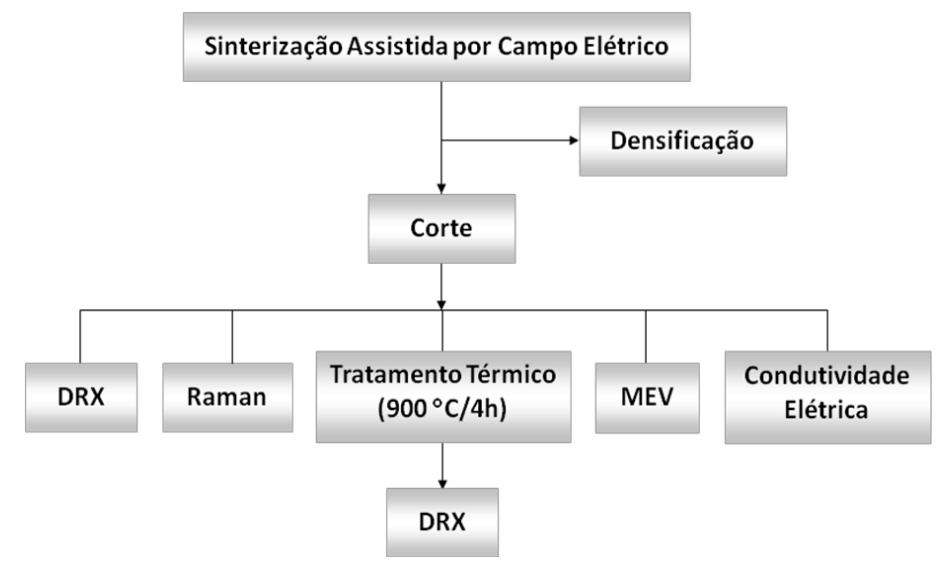

Figura 16. Fluxograma das etapas de caracterização das amostras sinterizadas por SPS.

\section{Técnicas de Caracterização}

Difração de Raios X

A técnica de difração de raios $X$ advém da interação de radiação eletromagnética com alta energia e pequeno comprimento de onda, da ordem dos espaçamentos atômicos dos sólidos, e a estrutura cristalina da matéria. Para isso, um feixe de raios $X$ deve incidir sobre um material cristalino em um ângulo $\theta$, que mostra o fenômeno de difração resultante da interação eletromagnética e a estrutura cristalina da matéria. 
Durante a interação radiação-átomo, uma série de interferências acontece, sendo que apenas as interferências construtivas transportam as informações estruturais na forma da radiação difratada ${ }^{(59)}$. As interferências construtivas produzem reflexões em certas direções definidas pela lei de Bragg, representada na Equação (1):

$$
n \lambda=2 d \operatorname{sen} \theta
$$

onde $n$ é um número inteiro que determina a ordem da difração, tipicamente igual a $1, \lambda$ o comprimento de onda da radiação incidente, $d$ a distância interplanar, isto é, a distância entre o planos cristalográficos $(h, k, l)$ e $d$ o ângulo de Bragg (incidência).

A distância entre dois planos de átomos paralelos e adjacentes é uma função dos índices de Miller ( $h, k$ e $l$ e dos parâmetros de rede $(a, b$ e $c)$. Para estruturas cristalinas com simetria cúbica, o parâmetro de rede (a) pode ser calculado pela seguinte Equação ${ }^{(59)}$ :

$$
a=d_{h k l} \sqrt{h^{2}+k^{2}+l^{2}}
$$

Dessa forma, a técnica de difração de raios $X$ é utilizada, principalmente, para a identificação de estruturas cristalinas e determinação dos parâmetros de rede. Em geral, a análise de fases num material cristalino é feita por comparação com os dados existentes num banco de dados Joint Commitee on Powder Difraction Standards (JCPDS) ou International Centre for Diffraction Data (ICDD).

\section{Análise Térmica}

De acordo com a Confederação Internacional de Análise Térmica e Calorimetria (ICTAC), a Análise Térmica é definida como: "Grupo de técnicas nas quais uma propriedade física de uma substância e/ou seus produtos de reação é medida como função da temperatura ou tempo, enquanto a substância é submetida a um programa controlado de temperatura" (60,61). Esta definição implica que para que uma técnica térmica possa ser considerada como termoanalítica, três critérios devem ser satisfeitos ${ }^{(62)}$ : 
1. Uma propriedade física tem que ser medida;

2. A medida deve ser expressa (direta ou indiretamente) como função da temperatura;

3. A medida tem que ser feita sob um programa controlado de temperatura.

Dentre as técnicas mais difundidas e utilizadas, pode-se destacar: Termogravimetria (TG), Análise Térmica Diferencial (DTA), Calorimetria Esploratória Diferencial (DSC) e Dilatometria ou Termodilatometria (TD). Estas técnicas permitem obter informações importantes, tais como: variação de massa, estabilidade térmica, água adsorvida, água ligada, ponto de fusão, ponto de ebulição, calores de transição, calores específicos, diagramas de fase, cinética da reação, estudos de catalisadores, transições vítreas, densificação, entre outros.

As medidas de variação (ganho ou perda) de massa são realizadas pela termogravimetria e a medida da diferença de temperatura entre uma amostra e um padrão é realizada pela análise térmica diferencial.

A dilatometria é uma técnica onde a variação na dimensão linear de uma amostra é medida durante um programa de temperatura controlado. Essa técnica é eficaz e muito utilizada nos estudos de sinterização ${ }^{(63)}$. O dilatômetro é utilizado para estudar a dependência entre a dilatação térmica linear e a temperatura de corpos sólidos, como metais, materiais cerâmicos, vidros, polímeros e outros.

\section{Densidade Aparente}

A densidade aparente de um material é definida pela relação de sua massa pelo seu volume, normalmente, expressa em gramas por centímetro cúbico $\left(\mathrm{g} / \mathrm{cm}^{3}\right)$. Neste trabalho, a densidade aparente dos compactos foi determinada pelos métodos geométrico e de imersão.

\section{Método Geométrico}

Este método consiste na determinação da massa, através de pesagem em balança, e das dimensões das amostras. 
Método de Imersão

Este método, também conhecido como método hidrostático, utiliza o princípio de Arquimedes. O procedimento para a determinação da densidade hidrostática $\left(\rho_{H}\right)$ dos corpos sinterizados foi primeiramente imergir esses corpos em água destilada, em seguida, ferver a água durante $2 \mathrm{~h}$ em placa aquecedora. O intuito de manter as amostras em água fervente é favorecer o preenchimento dos poros acessíveis existentes no material com dimensão igual ou superior ao da molécula de água. Após o resfriamento à temperatura ambiente, foram feitas pesagens das massas imersa $\left(m_{i}\right)$ e úmida $\left(m_{u}\right)$ e registrada a temperatura da água e do ar para determinação da densidade de ambos $\rho_{a}$ gua e $\rho_{a r}$, respectivamente. Em seguida, as amostras foram secas em estufa a $120{ }^{\circ} \mathrm{C}$, resfriadas e, novamente, pesadas $\left(m_{s}\right)$.

Por fim, a densidade hidrostática de amostras densas foi determinada a partir da Equação (3):

$$
\rho_{H}=\frac{\left(\rho_{\text {agud }} m_{s}\right)-\left(\rho_{a r} m_{i}\right)}{\left(m_{u}-m_{i}\right)}
$$

\section{Microscopia Eletrônica de Varredura}

A microscopia eletrônica de varredura é uma técnica muito utilizada na observação de alguns aspectos da microestrutura de materiais, tais como, o tamanho e a distribuição dos grãos e da porosidade. Essa técnica é capaz de fornecer imagens de alta ampliação e resolução, que permitem a obtenção de informações microestruturais de amostras diversas. O princípio de funcionamento do MEV baseia-se na interação entre um feixe de elétrons colimado e com alta energia e a superfície da amostra, onde parte do feixe é refletido e coletado pelo detector de elétrons retroespalhados e/ou secundários, convertendo este sinal em imagem. As observações ocorrem sob condições de vácuo, da ordem de $10^{-5}$ torr, necessário para evitar desvios no feixe de elétrons ${ }^{(64)}$. 
O feixe de elétrons que incide na amostra analisada, além de promover a emissão de elétrons secundários e retroespalhados, promove a emissão de raios $X$, os quais podem ser detectados por técnicas específicas. A espectroscopia de raios $X$ por dispersão de energia é uma técnica analítica usada para a análise elementar ou caracterização química semiquantitativa de uma amostra ${ }^{(64)}$. É uma das variantes da espectroscopia por fluorescência de raios $X$ que se baseia no mesmo princípio de interação da radiação com a matéria.

Nos microscópios eletrônicos de varredura, o feixe de elétrons incidente é proveniente de uma fonte termoiônica, comumente, um filamento de tungstênio, podendo ser também de hexaboreto de lantânio $\left(\mathrm{LaB}_{6}\right)$. Outro tipo de fonte empregada em microscopia eletrônica é a fonte de emissão eletrostática (Field Emission Electron Guns, FEG). Esta fonte, normalmente constituída por um monocristal de tungstênio na forma de um fio com uma ponta extremamente fina (cerca de $100 \mathrm{~nm}$ ), possibilita uma maior resolução do microscópio eletrônico, podendo se obter uma resolução de 1 a $2 \mathrm{~nm}^{(64)}$.

\section{Determinação do Tamanho Médio de Grãos}

O tamanho médio de grãos $(G)$ foi determinado utilizando-se o método de Mendelson ${ }^{(57)}$ ou método dos interceptos. O tamanho médio de grãos é dado pelo produto entre a média dos interceptos $(\bar{e})$ medidos e uma constante de proporcionalidade. $O$ tamanho médio de grãos é determinado pela Equação (4):

$$
G=1,56 \bar{e}
$$

Para o cálculo do tamanho médio de grãos foram feitas diversas imagens, em diferentes microrregiões de cada amostra, para ter uma estatística aceitável, de modo a serem analisados mais de 500 grãos por amostra. 
Os espectros Raman são obtidos irradiando-se uma amostra com uma fonte laser potente de radiação monocromática no visível ou no infravermelho próximo. Durante a irradiação, o espectro da radiação espalhada inelasticamente é medido em certo ângulo (frequentemente $90^{\circ}$ ) com um espectrômetro apropriado ${ }^{(65)}$. No efeito Raman, a atividade está ligada à variação do momento de dipolo induzido na molécula pelo campo elétrico da radiação incidente ${ }^{(66)}$.

A espectroscopia Raman tem sido aplicada a análises qualitativas e quantitativas de sistemas inorgânicos, orgânicos e biológicos. Esta técnica permite obter informações estruturais de materiais, através de análise direta de amostras sem necessidade de preparação ou manipulação de qualquer natureza.

\section{Espectroscopia de Impedância}

A espectroscopia de impedância tem sido aplicada como um dos instrumentos mais versáteis e sensíveis no estudo das propriedades específicas dos materiais como: propriedades elétricas, dielétricas, caracterização de defeitos microestruturais e transições de fases ${ }^{(67)}$.

Esta técnica consiste em submeter a amostra a ser analisada a uma tensão senoidal $V(\omega)=V_{0} \exp (j \omega t)$ de frequência variável fornecendo como resposta a corrente $I(t)=I_{\max } \exp (j \omega t+j \varphi)$, onde $\varphi$ é o ângulo de fase entre a tensão e a corrente. A impedância $Z^{\star}(\omega)$ pode então ser escrita segundo a equação:

$$
Z^{\star}(\omega)=\operatorname{Re}(Z)+j \operatorname{lm}(Z)=Z+j Z^{\prime}
$$

onde $\operatorname{Re}(Z)$ é a parte real, $\operatorname{Im}(Z)$ a parte imaginária da impedância $Z$ e $j$ é o operador imaginário $\sqrt{-1}$. 
As medidas de espectroscopia de impedância no estudo de eletrólitos sólidos foram inicialmente utilizadas por Bauerle ${ }^{(68)} \mathrm{em} 1969$, para a zircônia-ítria. Ele demonstrou, experimentalmente, que o diagrama de impedância de uma cerâmica policristalina é constituído por três semicírculos. O semicírculo na região de altas frequências está relacionado à condutividade no interior dos grãos; o semicírculo na região de frequências intermediárias está relacionado às reações nas interfaces do eletrólito (contornos de grão) e, o semicírculo na região de baixas frequências está relacionado às reações da interface eletrólito-eletrodo.

A Figura 17 mostra um diagrama de impedância idealizado contendo os três semicírculos, no qual é plotado o componente imaginário, $-Z^{\prime}$, da impedância em função do componente real, $Z$. Na Figura $17, R$ representa a resistência do grão $\left(R_{g}\right)$, do contorno de grão $\left(R_{c g}\right)$ e interfacial eletrólito-eletrodo $\left(R_{e l}\right)$. A seta indica o sentido do aumento da frequência angular $(\omega)$.

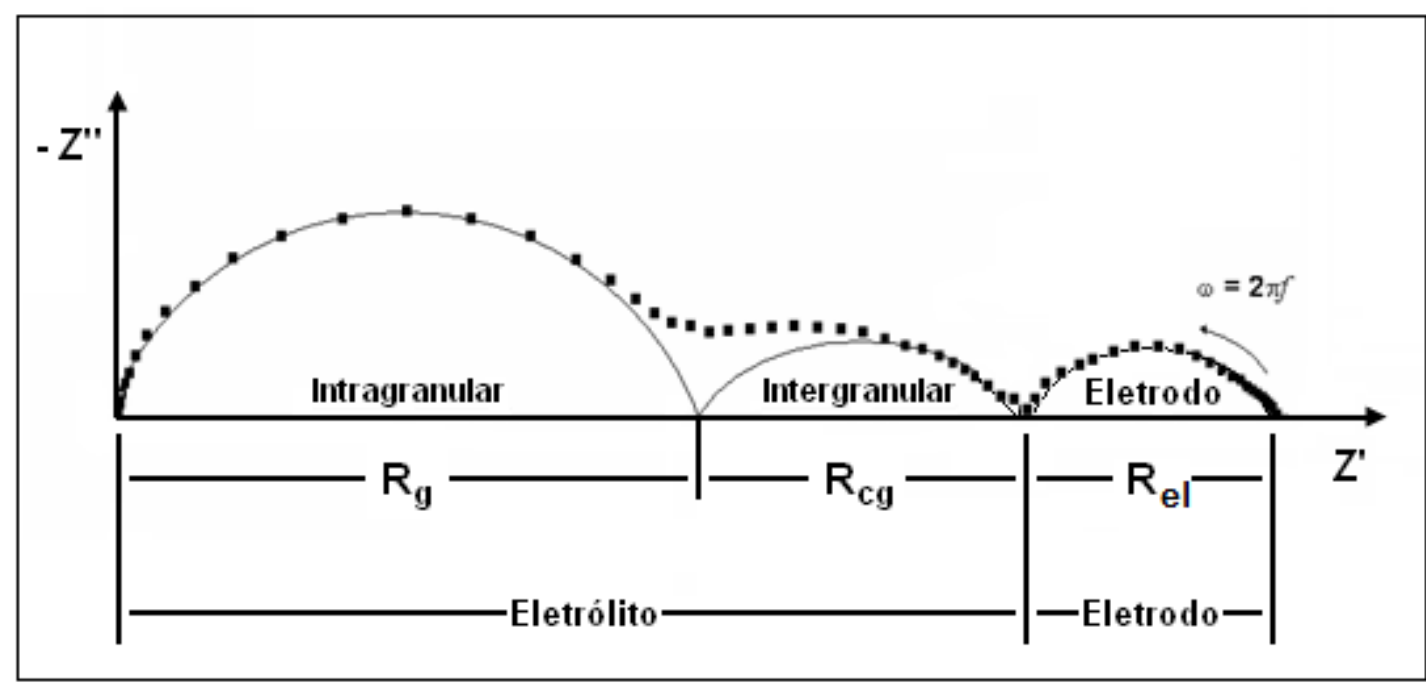

Figura 17. Esquema do diagrama de impedância idealizado contendo três semicírculos.

Dessa forma, para cada semicírculo, o diagrama de impedância permite obter informações sobre resistência, capacitância, frequência no ponto de máxima amplitude e ângulo de descentralização, em relação ao eixo real. De modo geral, a modelagem dos dados de impedância é realizada usualmente através de circuitos elétricos equivalentes, os quais descrevem os processos de polarização que ocorrem no material ${ }^{(67)}$. Dessa forma, a condutividade elétrica também pode ser calculada. 


\section{Condutividade Elétrica}

A resistência das amostras, determinada por medidas de espectroscopia de impedância, pode ser facilmente relacionada com a resistividade $(\rho)$ ou com a condutividade elétrica $(\sigma)$ do material pelas seguintes relações:

$$
R=\rho \frac{l}{S}
$$

onde lé a espessura e $S$ é a área seccional da amostra.

A partir da resistividade elétrica é calculada a condutividade elétrica:

$$
\rho=\frac{1}{\sigma}
$$

A dependência da condutividade elétrica com a temperatura pode ser obtida pela seguinte equação de Arrhenius:

$$
\sigma=\frac{\sigma_{0}}{T} \exp \left(-\frac{E_{a}}{k T}\right)
$$

onde, $\sigma_{0}$ é o fator pré-exponencial, $E_{a}$ a energia aparente de ativação para o processo de condução, $k$ a constante de Boltzmann e $T$ a temperatura absoluta.

A condutividade elétrica total $\left(\sigma_{T}\right)$ dos sólidos é dada pela soma das contribuições de todos os portadores de carga. Se o sólido apresentar diferentes tipos de portadores, a condutividade pode ser relacionada com cada portador de carga ${ }^{(69)}$. A condutividade elétrica é dada pela soma da condutividade eletrônica $\left(\sigma_{e l}\right)$ e iônica $\left(\sigma_{l o n}\right)$ segundo a Equação (9):

$$
\sigma_{T}=\sigma_{e l}+\sigma_{I o n}
$$

Para os condutores iônicos, a contribuição da condutividade eletrônica deve ser desprezível. 


\section{RESULTADOS E DISCUSSÃO}

Este capítulo é dividido em três seções principais, nas quais são apresentados os resultados referentes à caracterização do material como recebido, dos compactos sinterizados e, por fim, é realizada a análise do comportamento elétrico do material sinterizado pelos diferentes métodos.

\section{Caracterização do Material como Recebido}

De acordo com as informações fornecidas pelo fabricante o material utilizado neste trabalho possui $10 \%$ em mol de $\mathrm{Sc}_{2} \mathrm{O}_{3}$ e $1 \%$ em mol de $\mathrm{CeO}_{2}$, área de superfície específica igual a $11,5 \mathrm{~m}^{2} \cdot \mathrm{g}^{-1}$ e $99,98 \%$ de pureza.

O grau de pureza é um importante fator na escolha de materiais para aplicações tecnológicas e apresenta forte influência nas propriedades dos materiais. Além da Fuel Cell Materials, o 10Sc1CeSZ tem sido comercializado por outros fabricantes: a empresa japonesa Daiichi Kigenso Kagaku Kogyo (DKKK) e a americana Praxair Surface Technologies. Embora o material dessas duas empresas apresente pequenos desvios em relação à composição nominal, esses materiais apresentam elevado número de contaminantes, tais como: $\mathrm{Na}, \mathrm{Si}, \mathrm{Al}$ e $\mathrm{Ti}$, os quais foram detectados por espectrometria de massas de íons secundários

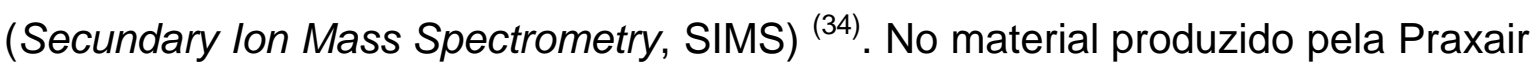
foi encontrado um alto teor de $\mathrm{TiO}_{2}$ igual a $0,18 \%$ em mol ${ }^{(34)}$. A presença de contaminantes, como $\mathrm{O} \mathrm{SiO}_{2}$, mesmo em pequenas quantidades, é indesejável em eletrólitos sólidos, uma vez que pode promover a degradação da condutividade elétrica ${ }^{(70)}$.

Inicialmente foi realizada a caracterização estrutural do material como recebido por difração de raios $X$. A partir do difratograma de raios $X$ do pó, apresentado na Figura 18, foi identificada uma única fase cúbica de face centrada (grupo espacial Fm3m) por comparação com a ficha JCPDS $n^{\circ}$ 89-5483 (Figura 3) com parâmetro de rede $a=5,090 \AA$, o qual é similar ao reportado na literatura ${ }^{(36,38)}$. Este resultado confirma que a introdução de cério na zircôniaescândia possibilita obter um pó com fase única cúbica à temperatura ambiente. 


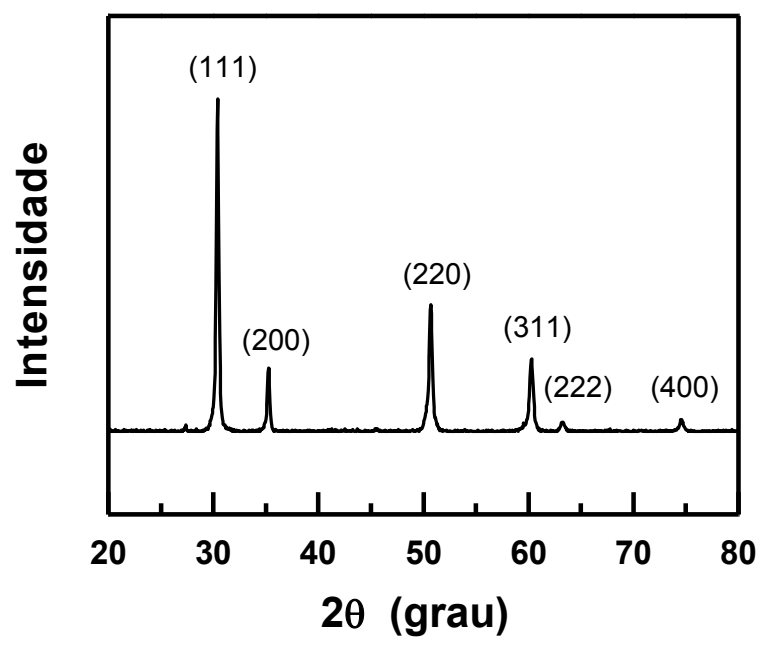

Figura 18. Difratograma de raios $X$ do pó de ScCeSZ como recebido.

A Figura 19 mostra as micrografias do pó de ScCeSZ, como recebido, obtidas por microscópio eletrônico de varredura. São observados aglomerados esféricos com diferentes diâmetros inferiores a $100 \mu \mathrm{m}$ e constituídos por partículas com tamanhos nanométricos.
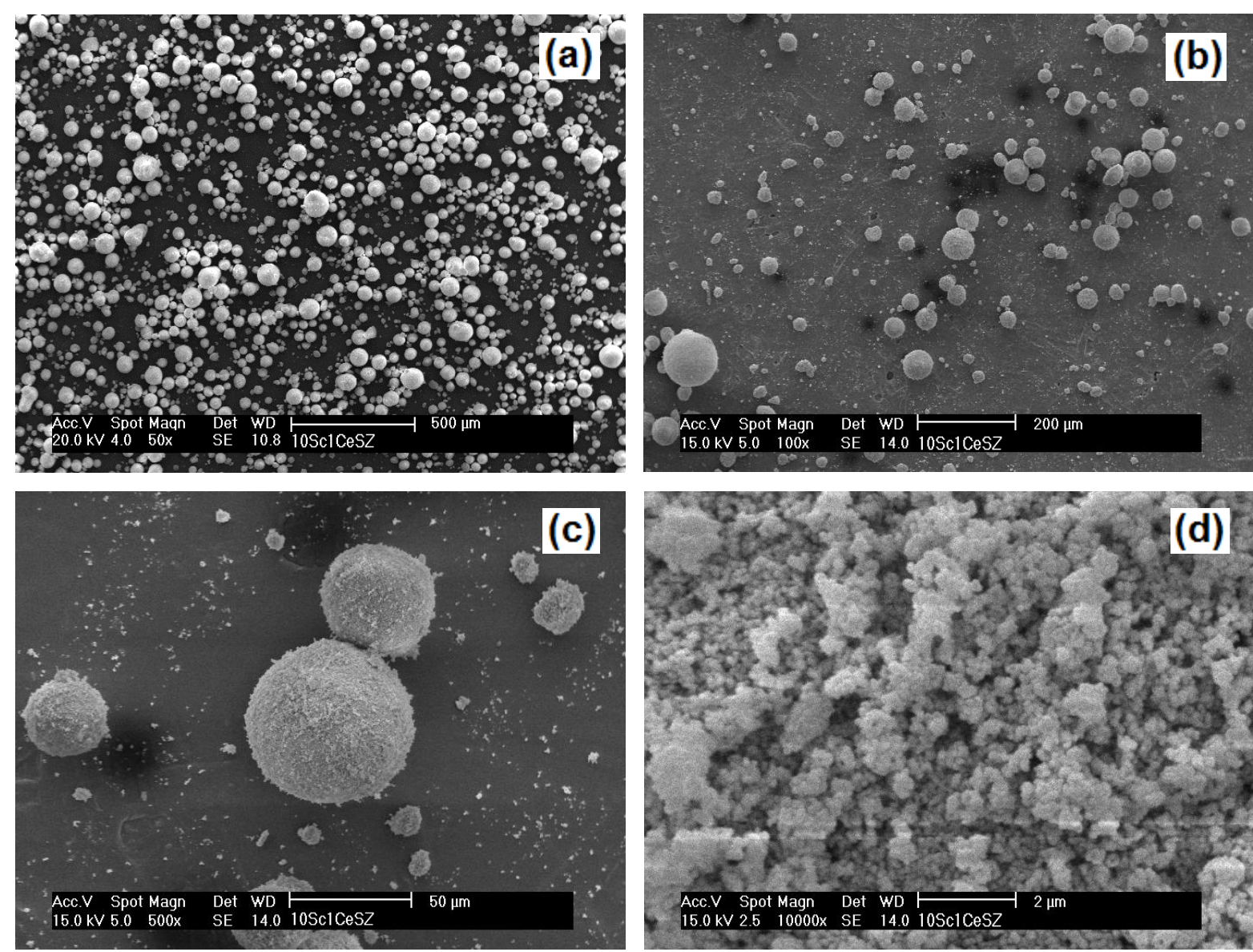

Figura 19. Micrografias do pó de ScCeSZ como recebido em aumentos de a) 50x, b) $100 x$, c) $500 x$ e d) $10000 x$. 
A Figura 20 mostra as curvas termogravimétrica e de análise térmica diferencial da zircônia-escândia-céria. Nenhuma variação significativa de massa foi observada para o ScCeSZ na faixa de temperatura investigada. A curva DTA mostra que nenhum evento endo ou exotérmico foi detectado no intervalo de temperatura investigado. De modo geral, as transições de fase são facilmente evidenciadas por análise térmica, como foi observado para a transição de fase cúbica $\leftrightarrow$ romboédrica na zircônia-escândia ${ }^{(71)}$. Neste caso, a ausência de qualquer evento térmico durante o aquecimento e resfriamento do material descarta a possibilidade de transição de fase reversível nas condições utilizadas neste experimento. Comparativamente, o material produzido pela empresa DKKK apresenta transição de fase cúbica $\leftrightarrow$ romboédrica no intervalo de temperatura de 300 a $500{ }^{\circ} \mathrm{C}$ evidenciada por difração de raios $\mathrm{X}$ a alta temperatura ${ }^{(34)}$.

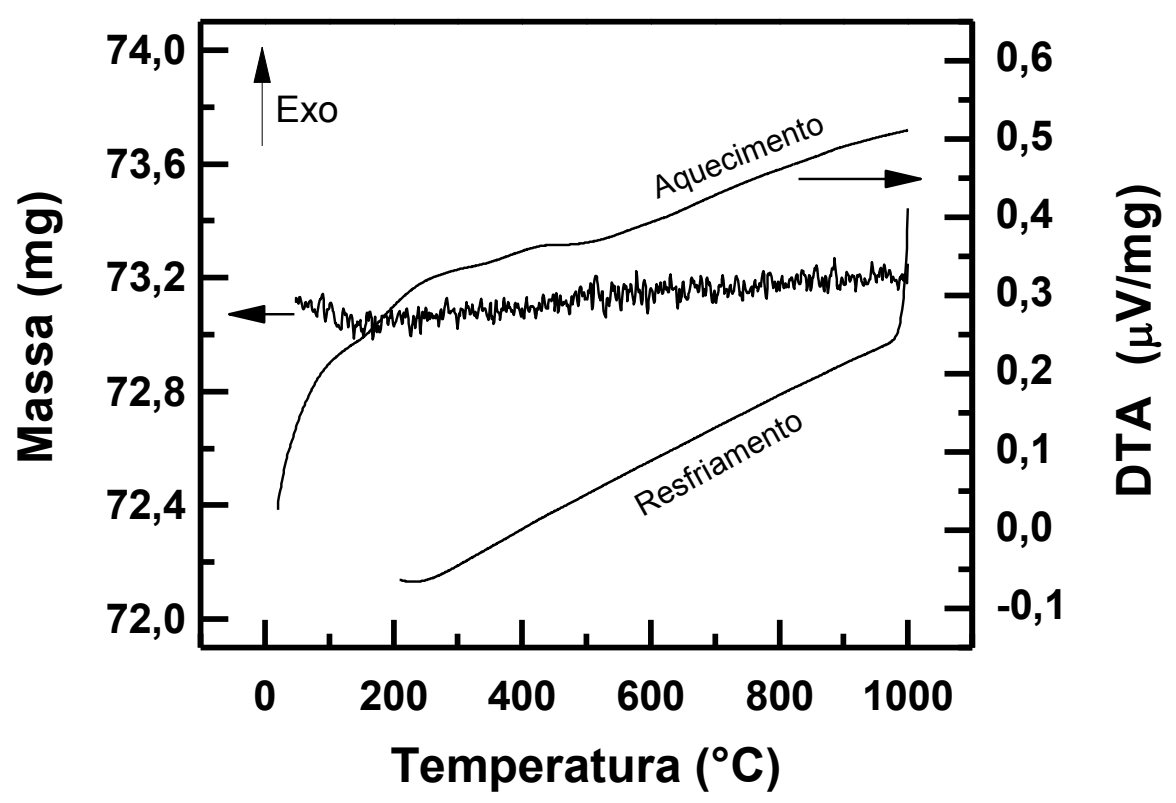

Figura 20. Curvas termogravimétrica (TG) e de análise térmica diferencial (DTA), obtidas em atmosfera de ar sintético com taxa de aquecimento e resfriamento de $10^{\circ} \mathrm{C} / \mathrm{min}$, do material como recebido.

Para a caracterização estrutural do material após ser submetido à análise térmica, realizou-se a difração de raios X. A Figura 21 mostra o difratograma de raios $\mathrm{X}$ do pó após ser submetido a $1000{ }^{\circ} \mathrm{C}$ e resfriado à temperatura ambiente. Apenas a fase cúbica de face centrada foi observada. 


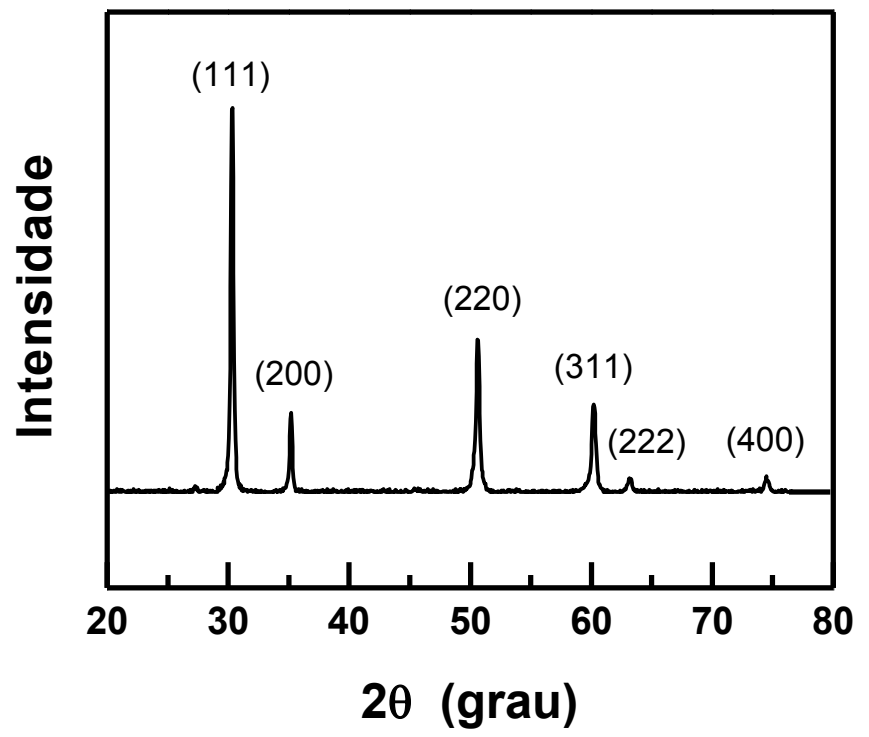

Figura 21. Difratograma de raios $X$ do pó de ScCeSZ após ser submetido à análise térmica.

Estes resultados de difração de raios $\mathrm{X}$ e análise térmica confirmam que a adição de céria à zircônia-escândia promove a estabilização da fase cúbica à temperatura ambiente e que o material como recebido apresenta estabilidade sob condições de ciclagem térmica até $1000^{\circ} \mathrm{C}$.

\section{Sinterização e Caracterização dos Compactos}

O estudo da sinterização do ScCeSZ pelos três métodos empregados neste trabalho e a caracterização das amostras serão discutidos nesta seção.

\section{Dilatometria}

A Figura 22 mostra a curva de retração linear, com sua derivada, de um compacto a verde de ScCeSZ obtida através de dilatometria. A variação dimensional até $1050^{\circ} \mathrm{C}$ é desprezível. A retração linear do compacto ocorreu entre 1050 e $1380{ }^{\circ} \mathrm{C}$, sendo que a retração total até $1380{ }^{\circ} \mathrm{C}$ foi de $21 \%$. A derivada da retração linear mostra um único ponto de inflexão associado à máxima taxa de retração do material a $1180^{\circ} \mathrm{C}$. Estes resultados estão de acordo com a curva de retração linear do ScCeSZ preparado por coprecipitação (DKKK) ${ }^{(34)}$ e flame spray ${ }^{(36)}$. 


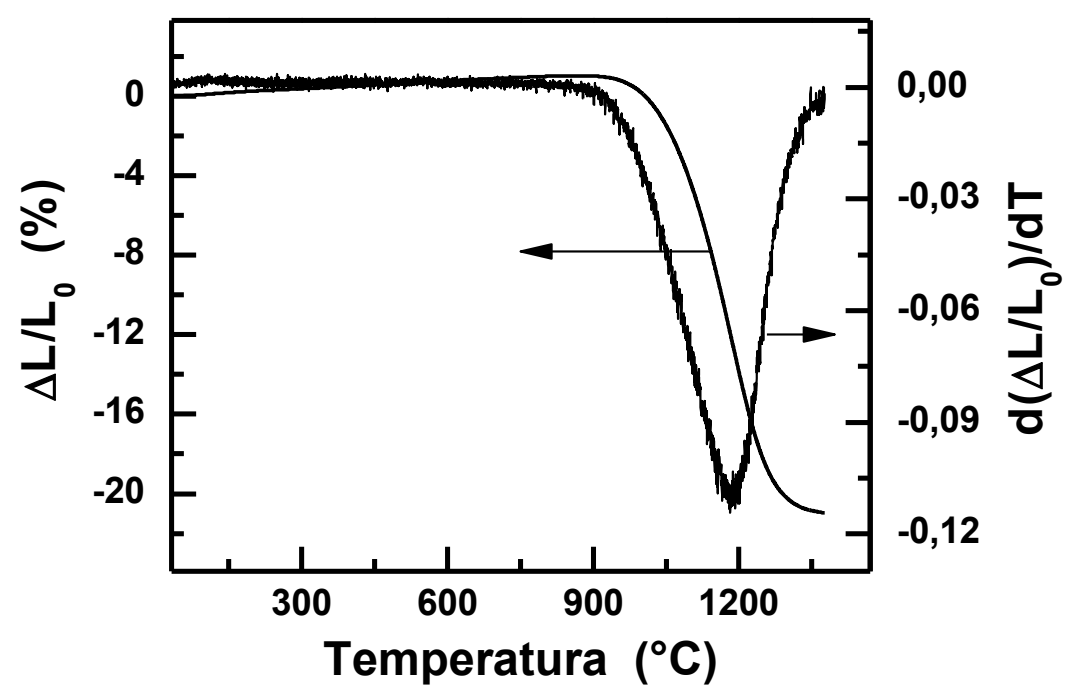

Figura 22. Retração linear do compacto de ScCeSZ e sua derivada.

\section{Sinterização Convencional}

A Figura 23 mostra o comportamento da densidade relativa, obtida por meio da retração linear de um compacto a verde via dilatometria, e método geométrico de amostras sinterizadas pelo método convencional em tempo de patamar nulo, em função da temperatura. $\mathrm{O}$ aumento da temperatura promoveu o aumento da densidade relativa, como esperado. Para temperaturas superiores a $1250{ }^{\circ} \mathrm{C}$ há diminuição na taxa de densificação, ou seja, a densidade aumenta mais lentamente com a temperatura. A partir das curvas, pode-se perceber que há um bom acordo entre os dados obtidos pela retração linear e método geométrico. $\mathrm{O}$ valor superior obtido por dilatometria a $100{ }^{\circ} \mathrm{C}$ pode ser explicado com base na geometria das amostras a verde, uma vez que a sinterização tem início a $1050{ }^{\circ} \mathrm{C}$ (Figura 22). As amostras compactadas para análise de dilatometria apresentaram densidade relativa a verde ligeiramente superior, cerca de $45 \%$, enquanto que as amostras conformadas para sinterização pelo método convencional apresentaram aproximadamente $40 \%$ de densidade relativa (Capítulo 2).

A pequena diferença entre os valores encontrados a partir de $1100{ }^{\circ} \mathrm{C}$ ocorreu devido ao processo de resfriamento das amostras sinterizadas pelo método convencional (Figura 11). Enquanto que, as densidades geométricas relativas foram determinadas após resfriamento das amostras sinterizadas, os valores de densidade, calculados a partir da retração linear extraídos da curva de dilatometria, foram coletados durante o aquecimento do material. 


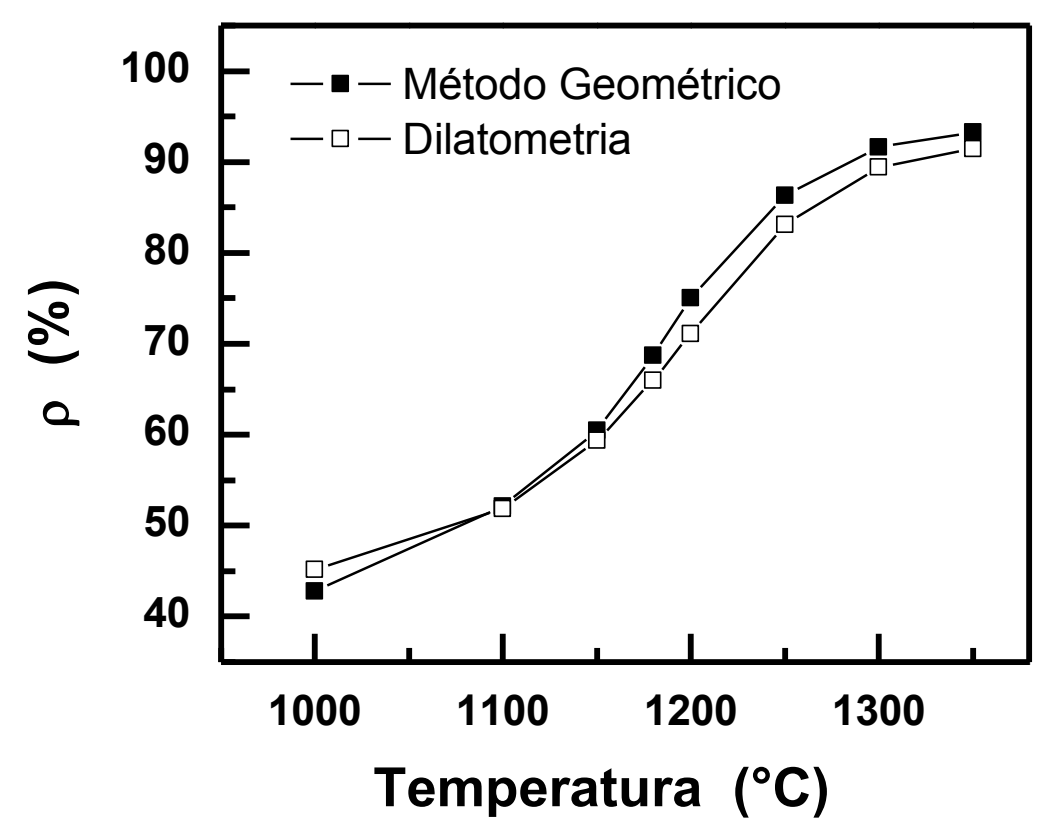

Figura 23. Curvas de densidade relativa em função da temperatura.

A sinterização pelo método convencional foi realizada com o objetivo de verificar faixas de temperaturas adequadas para a realização da sinterização em duas etapas, bem como, servir de método comparativo.

De acordo com os trabalhos pioneiros de sinterização em duas etapas, a temperatura de pico $\left(T_{1}\right)$ deve ser selecionada de acordo com uma densidade relativa em torno de $75 \%$ da densidade teórica para materiais que sinterizam por meio de reações em estado sólido ${ }^{(43)}$. Dessa forma, para a cerâmica de ScCeSZ, a princípio, foi utilizada $T_{1}$ igual a $1200^{\circ} \mathrm{C}$.

No entanto, após sinterização das amostras entre 1150 e $1300{ }^{\circ} \mathrm{C}$, em tempo de patamar nulo, ocorreu a formação de uma fase secundária, a qual é evidenciada pelos difratogramas de raios $X$ na Figura 24 . Os picos nos difratogramas com a marcação $(\beta)$ são atribuídos à fase romboédrica (9) (Figura 3). A sinterização a $1200{ }^{\circ} \mathrm{C}$ promoveu a maior quantidade de fase romboédrica. O aumento da temperatura de sinterização promoveu a predominância de uma estrutura cúbica com pequena quantidade da fase secundária. Apenas a partir de $1350{ }^{\circ} \mathrm{C}$, o material apresentou-se cúbico monofásico. Esse comportamento, reportado para o ScCeSZ desenvolvido pela empresa DKKK ${ }^{(34)}$ também foi observado na zircônia-escândia contendo 1\% em mol de alumina ${ }^{(24)}$. 
A sinterização em baixa temperatura $\left(<1100{ }^{\circ} \mathrm{C}\right)$, região do primeiro estágio de sinterização (Figura 7), promoveu a formação de picos alargados nos difratogramas devido ao pequeno tamanho de partículas e/ou cristalitos altamente desordenados. Sendo que o material é cúbico com quantidade de fase secundária ausente ou desprezível (considerando os limites de detecção da técnica) ${ }^{(59)}$, como pode ser observado na Figura 24b. A Figura 24b mostra os difratogramas de raios $X$ na faixa de $2 \theta$ entre 48 e $53^{\circ}$, onde os picos referentes aos índices de Miller (220) correspondente à fase cúbica e (104) e (110) à fase romboédrica são encontrados ${ }^{(10)}$. Alguns picos nos difratogramas de raios $X$ apresentaram ligeiros deslocamentos provocados por pequenos desalinhamentos da amostra com o feixe incidente.
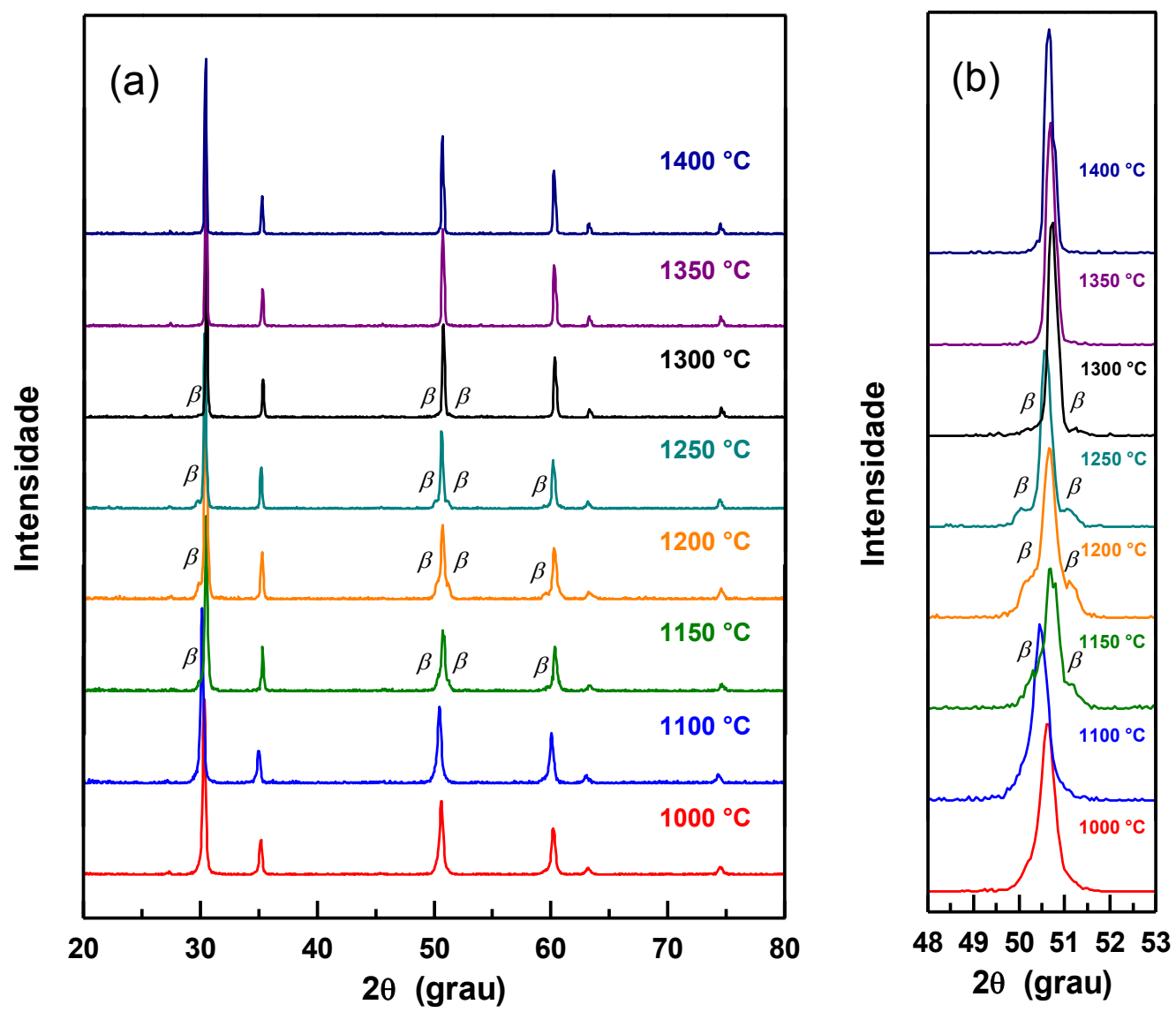

Figura 24. Difratogramas de raios $X$ de amostras de ScCeSZ sinterizadas a várias temperaturas por tempo de patamar nulo na faixa de $2 \theta$ entre (a) 20 e $80^{\circ}$ e (b) 48 e $53^{\circ}$. 
Para uma análise mais detalhada da densificação do material em função do tempo, várias condições de sinterização pelo método convencional foram estudadas. A Figura 25 mostra as curvas de densidade geométrica relativa em função do tempo de patamar para cada temperatura de sinterização. A densificação do ScCeSZ torna-se efetiva a partir de $1150{ }^{\circ} \mathrm{C}$. Abaixo de $1150^{\circ} \mathrm{C}$ é necessário tempo de patamar muito extenso (cerca de $10 \mathrm{~h}$ ) para se atingir uma densidade relativa próxima de $90 \%$. Pode-se observar que há um salto na densidade relativa devido ao aumento no tempo de patamar de 0 a $0,2 \mathrm{~h}$ entre as temperaturas de 1150 e $1200{ }^{\circ} \mathrm{C}$, ou seja, a densificação ocorre num curto intervalo de tempo, para temperaturas superiores a $1150^{\circ} \mathrm{C}$. A elevada mobilidade dos cátions em altas temperaturas promove a rápida densificação da cerâmica. Assim, para a temperatura de $1350^{\circ} \mathrm{C}$, por exemplo, a densidade relativa é superior a $90 \%$ mesmo com tempo nulo de patamar.

Os valores de densidade foram calculados baseando-se na densidade da zircônia-escândia-céria cúbica. No entanto, algumas amostras apresentaram quantidades significativas de fase romboédrica, o que pode levar a valores de densidade diferentes dos calculados. 

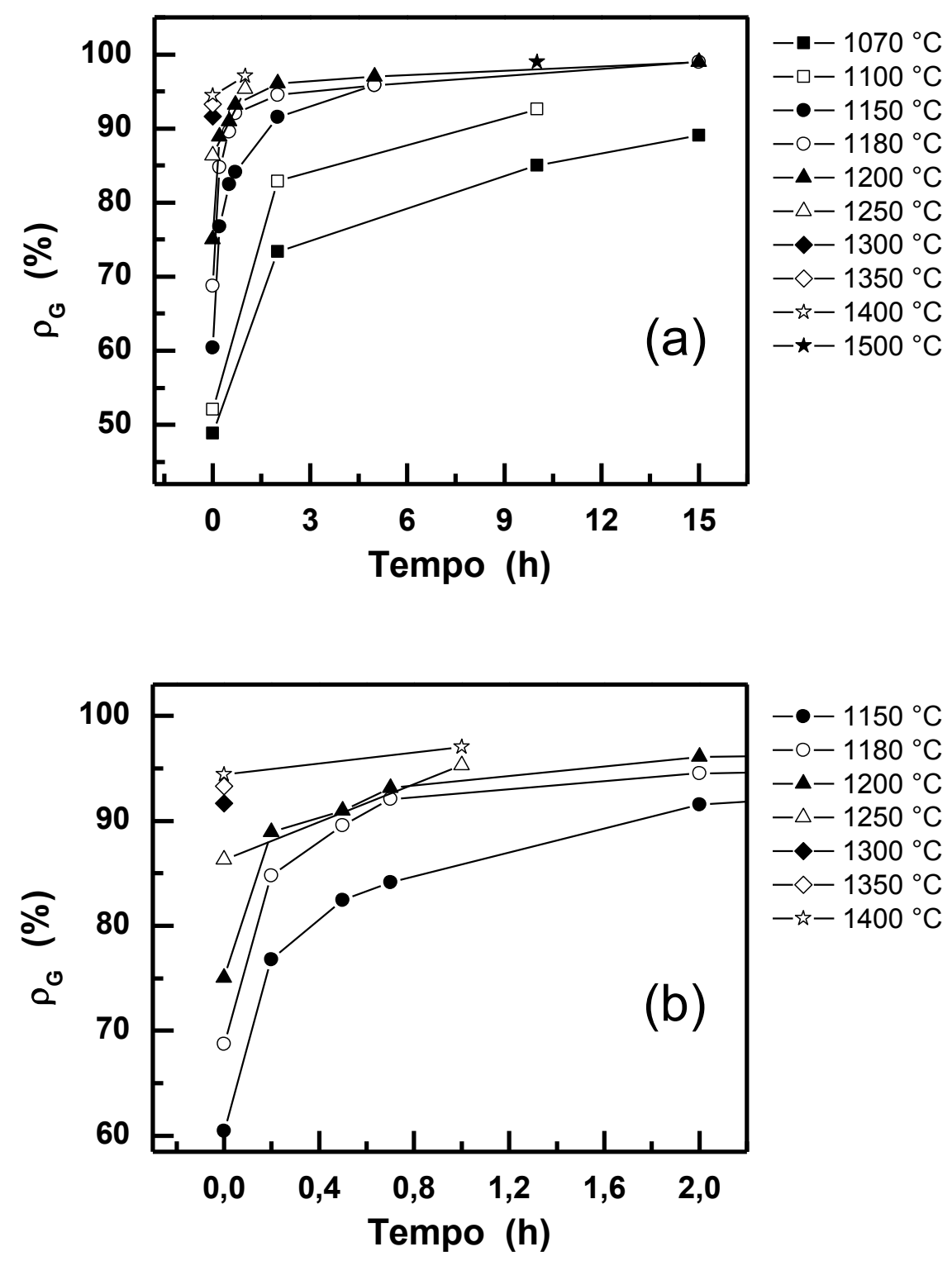

Figura 25. Curva de densidade geométrica relativa em função do tempo para as temperaturas de sinterização estudadas por método convencional. Intervalo de tempo de (a) 0 a $15 \mathrm{~h} \mathrm{e} \mathrm{(b)} 0$ a $2 \mathrm{~h}$.

Para a otimização de $T_{2}$ na sinterização em duas etapas foi realizada a caracterização estrutural das amostras sinterizadas por método convencional. A Figura 26 mostra os difratogramas de raios $X$ das amostras sinterizadas por 2 horas a várias temperaturas. $O$ aumento da temperatura promoveu a diminuição gradual da fase secundária $\beta$ e a predominância da fase cúbica. Considerando o tempo de patamar de $2 \mathrm{~h}$, nenhum pico referente à fase romboédrica foi identificado somente para temperaturas igual ou superior a $1200^{\circ} \mathrm{C}$. 


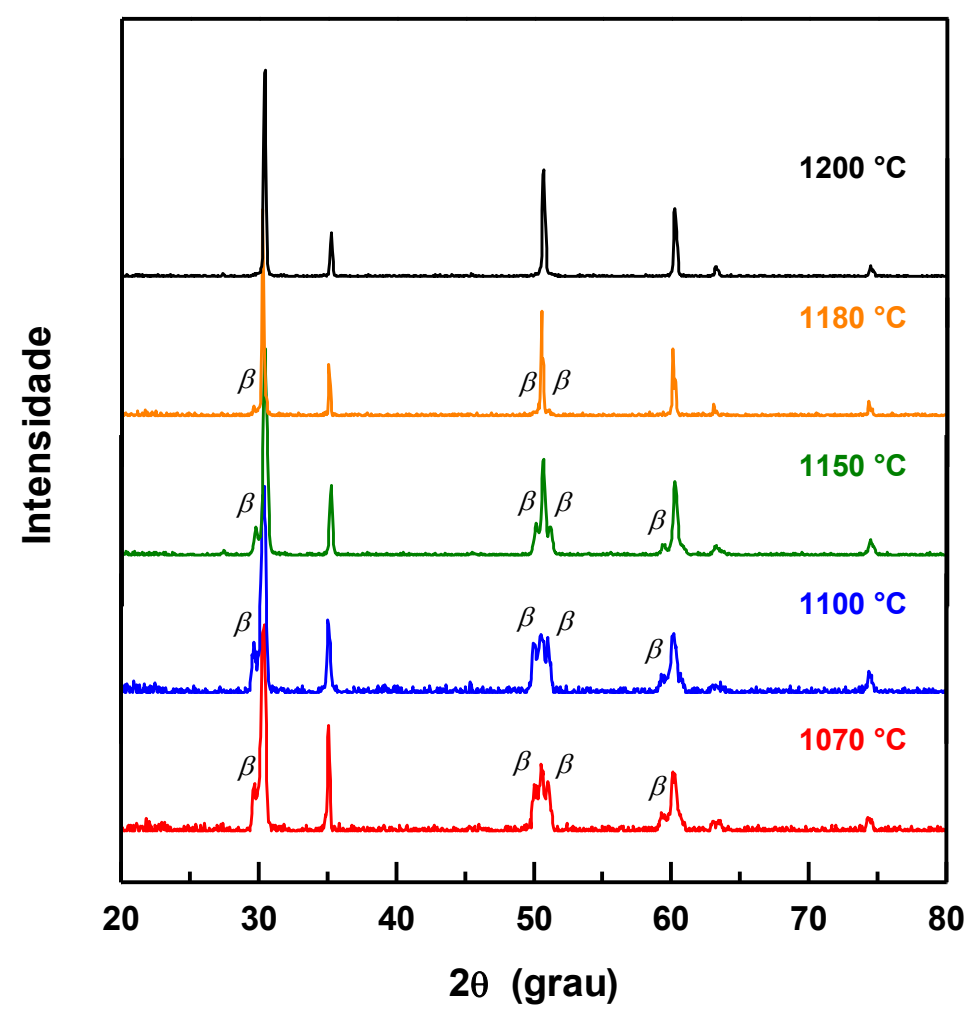

Figura 26. Difratogramas de raios $X$ de amostras de ScCeSZ sinterizadas a várias temperaturas por 2 horas.

A Figura 27 mostra os difratogramas de raios $X$ das amostras sinterizadas a $1200{ }^{\circ} \mathrm{C}$ por vários tempos. Observa-se que o aumento do tempo de patamar a $1200{ }^{\circ} \mathrm{C}$ promoveu a predominância da fase cúbica. O material tornou-se monofásico a partir de 2 horas. Pelo fato de, os difratogramas das fases cúbica e tetragonal serem muito semelhantes, os picos na faixa de $2 \theta$ entre 73 e $76^{\circ}$, onde é possível diferenciar as fases cúbica e tetragonal, são destacados na Figura 27b. Por comparação com os difratogramas de raios $X$ apresentados na Figura $3 b$, os picos nesta faixa indicam a presença da fase cúbica. 

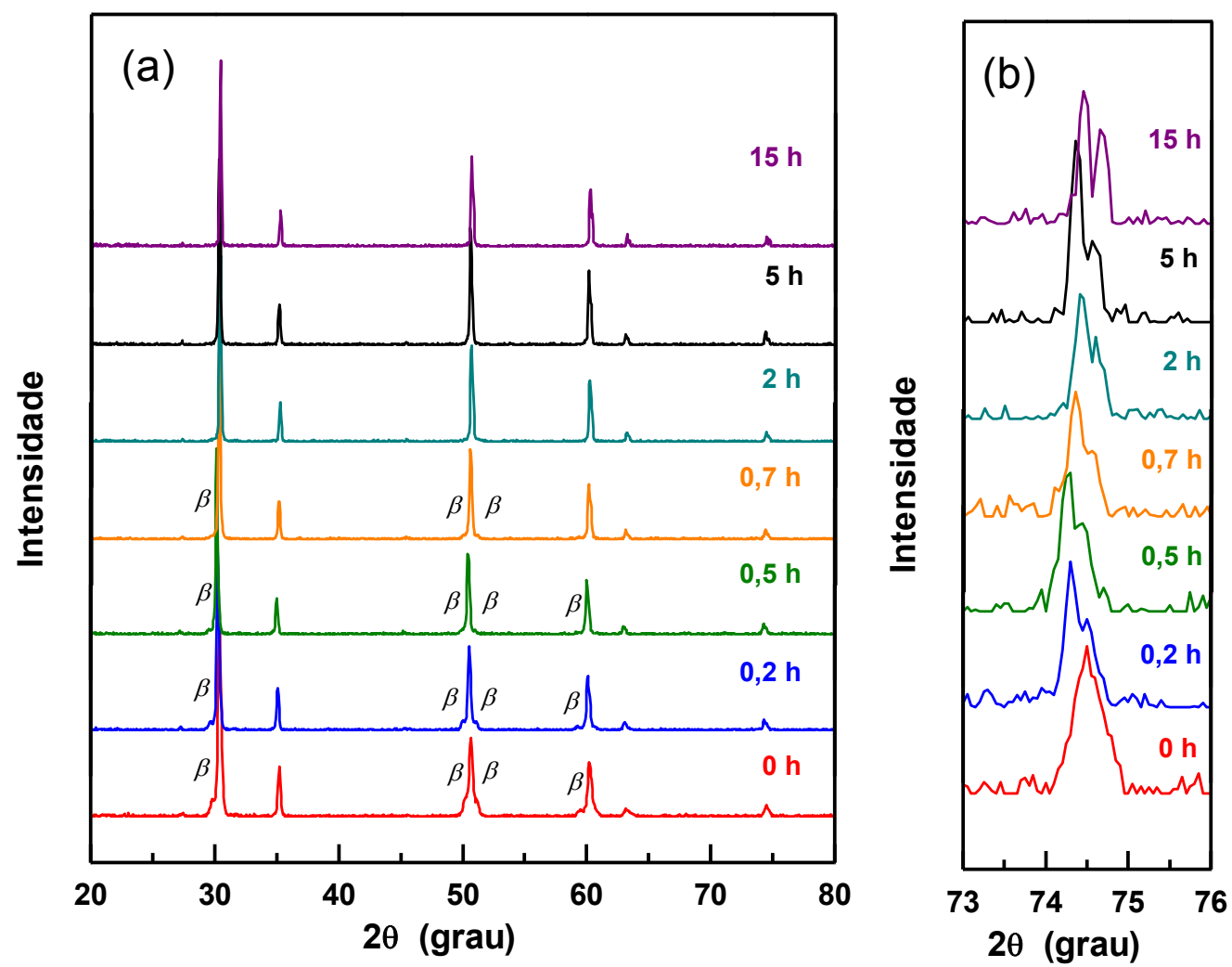

Figura 27. Difratogramas de raios $X$ de amostras de ScCeSZ sinterizadas a $1200{ }^{\circ} \mathrm{C}$ por vários tempos de patamar. Faixa de $2 \theta$ entre (a) 20 e $80^{\circ}$ e (b) 73 e $76^{\circ}$.

A Figura 28 mostra os difratogramas de raios $\mathrm{X}$ das amostras sinterizadas a várias temperaturas por tempo de patamar prolongado. Diferentemente do comportamento observado a $1200{ }^{\circ} \mathrm{C}$ (Figura 27), o aumento do tempo de patamar promoveu a predominância da fase romboédrica. Embora a sinterização a $1180{ }^{\circ} \mathrm{C}$ por $5 \mathrm{~h}$ tenha favorecido a predominância da fase cúbica, o tempo de $15 \mathrm{~h}$ de patamar promoveu a formação excessiva da fase romboédrica. A sinterização a $1500{ }^{\circ} \mathrm{C}$ por $10 \mathrm{~h}$ também promoveu a formação da fase $\beta$. Neste caso, provavelmente ocorreu um excesso de sinterização (overfiring). 


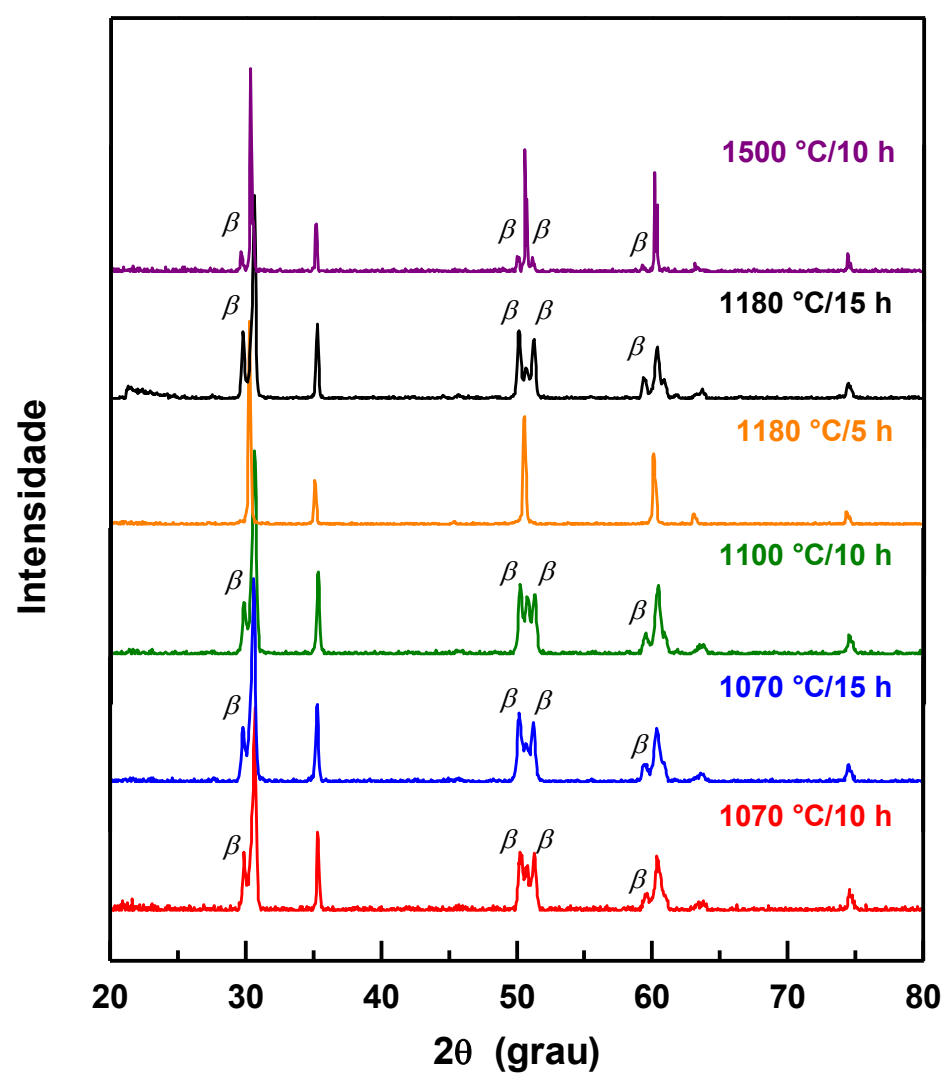

Figura 28. Difratogramas de raios $\mathrm{X}$ de amostras de ScCeSZ sinterizadas por tempos prolongados.

Os resultados de difração de raios $X$ mostram, de forma geral, que é necessária uma seleção cuidadosa das condições de sinterização para obtenção do material cúbico monofásico.

A Figura 29 mostra as micrografias da superfície de fratura da amostra sinterizada a $1200{ }^{\circ} \mathrm{C}$ por tempo de patamar nulo obtidas por microscópio eletrônico de varredura com fonte de emissão eletrostática em diferentes aumentos. Observa-se que a porosidade está distribuída aleatoriamente. O tamanho médio de grãos foi estimado em aproximadamente $0,1 \mu \mathrm{m}$, o qual é similar ao tamanho dos aglomerados observados nas micrografias do pó (Figura 19). Dessa forma, as micrografias evidenciam que a $1200{ }^{\circ} \mathrm{C}$ o ScCeSZ está no estágio intermediário de sinterização (densidade relativa igual a 75\%). 

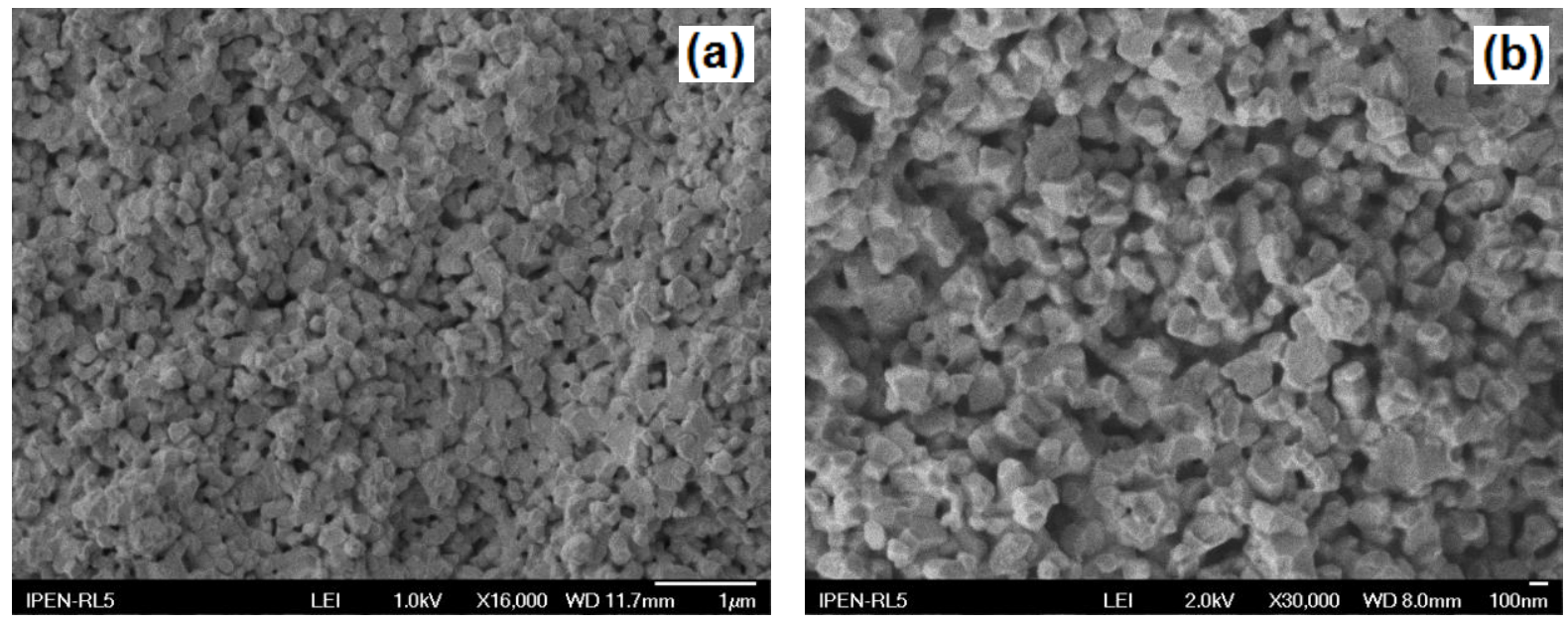

Figura 29. Micrografias da superfície de fratura da amostra de ScCeSZ sinterizada pelo método convencional a $1200{ }^{\circ} \mathrm{C}$ por tempo de patamar nulo. (a) Aumento menor e (b) maior.

A Figura 30 mostra as micrografias obtidas por microscópio eletrônico de varredura das amostras sinterizadas a $1200^{\circ} \mathrm{C}$ por 0,2 e $2 \mathrm{~h}, 1250{ }^{\circ} \mathrm{C}$ por $1 \mathrm{~h}$ e $1300{ }^{\circ} \mathrm{C}$ por tempo de patamar nulo. Pode-se observar que a $1200{ }^{\circ} \mathrm{C}$ por $0,2 \mathrm{~h}$ há baixa uniformidade no tamanho dos grãos. O aumento da temperatura promoveu a diminuição da porosidade e o consequente aumento dos grãos, propiciando boa homogeneidade microestrutural. $O$ aumento do tempo de patamar também apresenta forte influência na microestrutura do material. Para estas condições de sinterização, o tamanho médio de grãos é inferior a $1 \mu \mathrm{m}$, apesar da distribuição de tamanho ser relativamente alargada. 


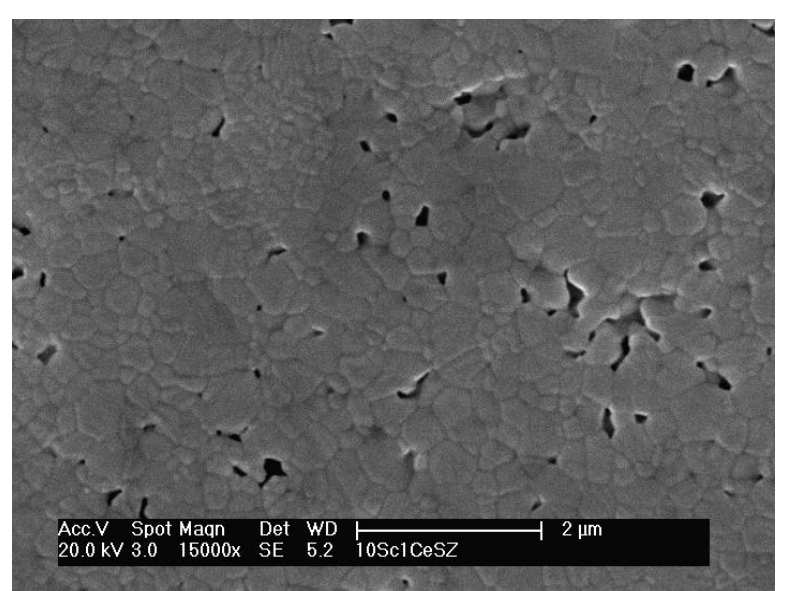

(a) $1200^{\circ} \mathrm{C} / 0,2 \mathrm{~h}$

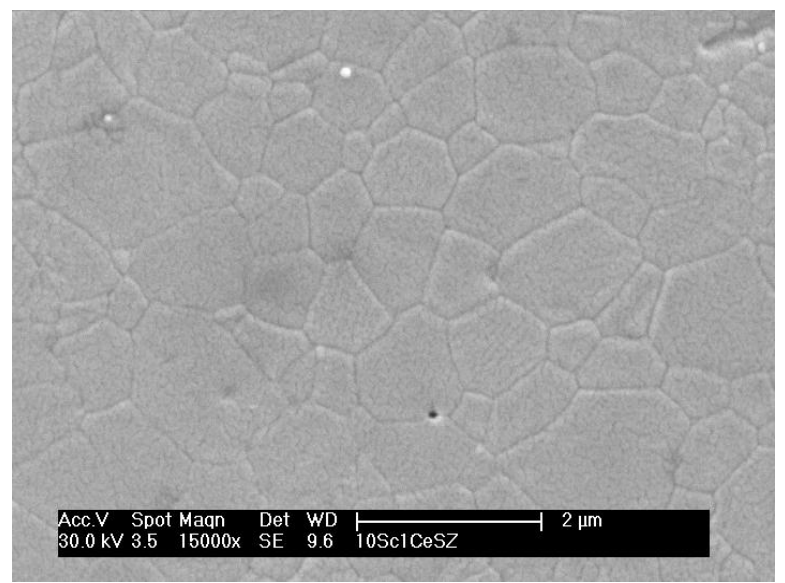

(c) $1250^{\circ} \mathrm{C} / 1 \mathrm{~h}$

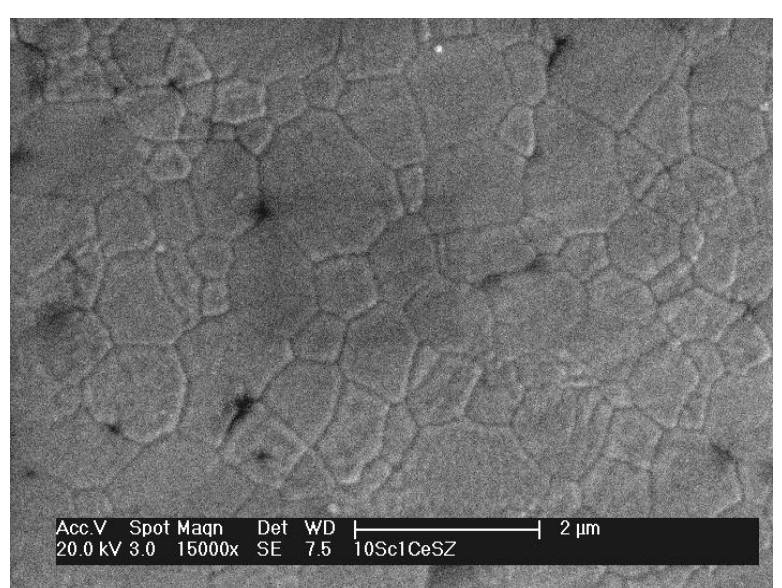

(b) $1200^{\circ} \mathrm{C} / 2 \mathrm{~h}$

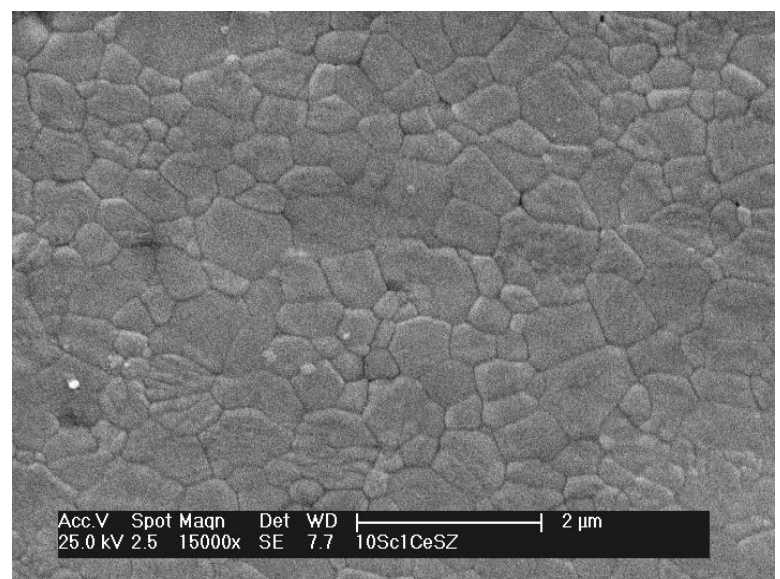

(d) $1300{ }^{\circ} \mathrm{C} / 0 \mathrm{~h}$

Figura 30. Micrografias de amostras de ScCeSZ sinterizadas pelo método convencional: (a) $1200{ }^{\circ} \mathrm{C}$ por $0,2 \mathrm{~h}$, (b) $1200{ }^{\circ} \mathrm{C}$ por $2 \mathrm{~h}$, (c) $1250{ }^{\circ} \mathrm{C}$ por $1 \mathrm{~h} \mathrm{e} \mathrm{(d)} 1300{ }^{\circ} \mathrm{C}$ por tempo de patamar nulo.

As micrografias das amostras sinterizadas nos tempos de patamar de $0,5 \mathrm{e}$ $5 \mathrm{~h}$ a $1200^{\circ} \mathrm{C}$ e em tempo de patamar nulo a 1300 e $1400{ }^{\circ} \mathrm{C}$ são mostradas na Figura 31. Apenas a micrografia da amostra sinterizada a $1200^{\circ} \mathrm{C}$ por $5 \mathrm{~h}$ está em escala reduzida. Observa-se que a porosidade é eliminada após sinterização a $1200{ }^{\circ} \mathrm{C}$ por $0,5 \mathrm{~h}\left(\rho_{H}=96,6 \%\right)$ e que ocorreu um ligeiro aumento do tamanho dos grãos com o aumento do tempo de patamar para $5 \mathrm{~h}$. Por outro lado, o aumento da temperatura de 1300 para $1400{ }^{\circ} \mathrm{C}$ promoveu um aumento significativo do tamanho médio dos grãos. 


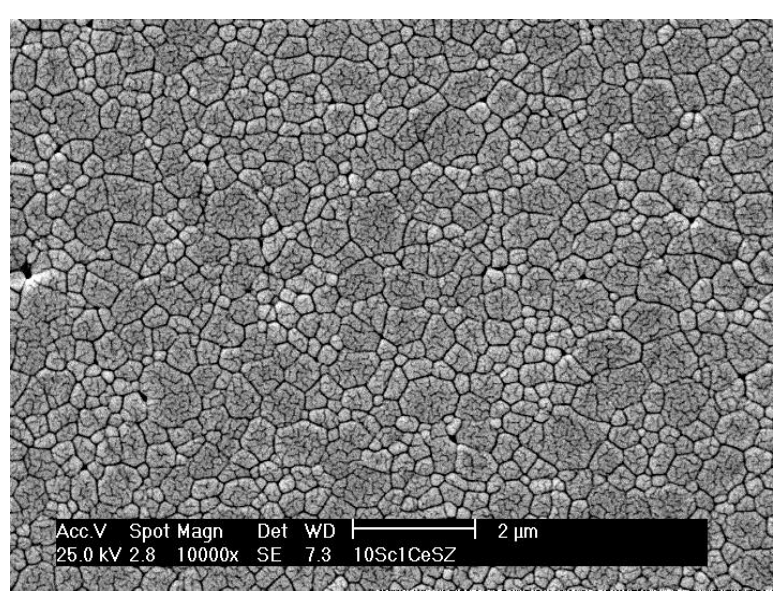

(a) $1200^{\circ} \mathrm{C} / 0,5 \mathrm{~h}$

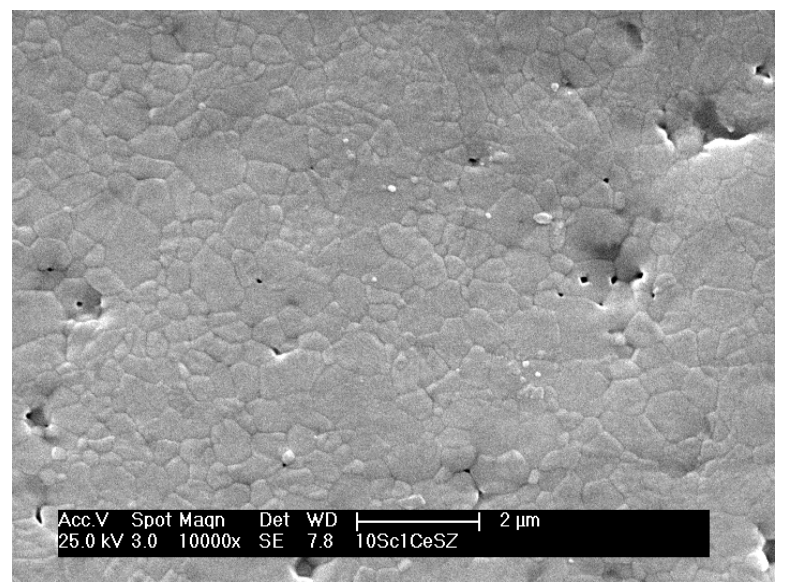

(c) $1300^{\circ} \mathrm{C} / 0 \mathrm{~h}$

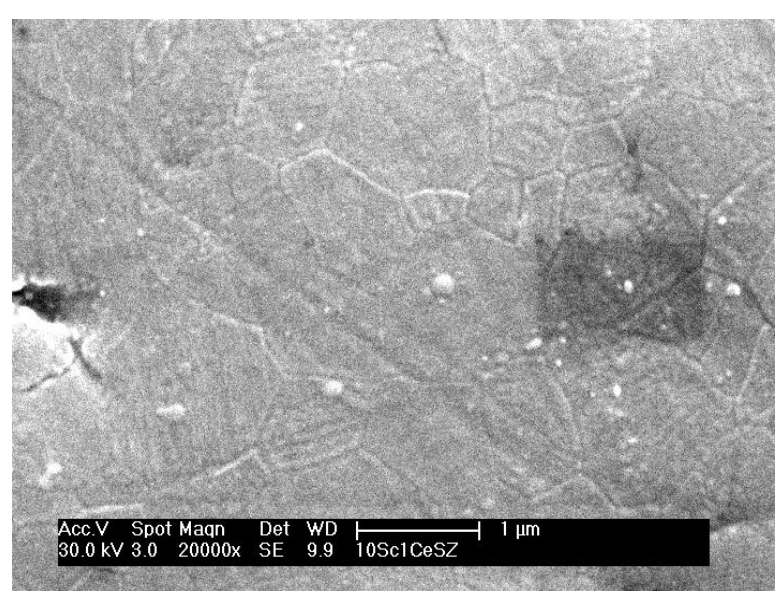

(b) $1200^{\circ} \mathrm{C} / 5 \mathrm{~h}$

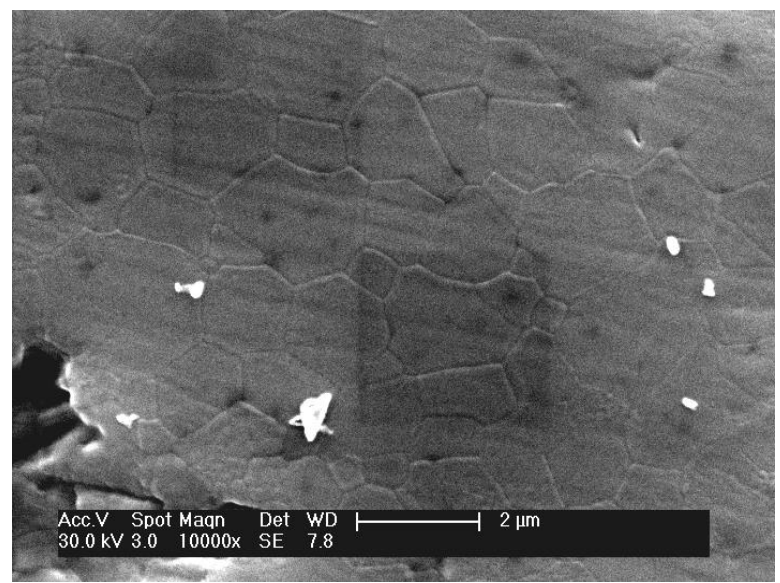

(d) $1400{ }^{\circ} \mathrm{C} / 0 \mathrm{~h}$

Figura 31. Micrografias de amostras de ScCeSZ sinterizadas pelo método convencional: (a) $1200{ }^{\circ} \mathrm{C}$ por $0,5 \mathrm{~h}$, (b) $1200{ }^{\circ} \mathrm{C}$ por $5 \mathrm{~h}$, (c) $1300^{\circ} \mathrm{C}$ por $0 \mathrm{~h} \mathrm{e} \mathrm{(d)} 1400^{\circ} \mathrm{C}$ por $0 \mathrm{~h}$.

De modo geral, em amostras densas, sinterizadas pelo método convencional, a porosidade residual permanece nos contornos de grãos e os grãos permanecem em formato poligonal.

A análise composicional semiquantitativa por espectroscopia de energia dispersiva de raios $X$ foi realizada na amostra sinterizada a $1400^{\circ} \mathrm{C}$ por tempo de patamar nulo. Foram selecionadas aleatoriamente cinco microrregiões distintas. De acordo com a análise por EDS, o material apresenta a seguinte composição molar: $8 \%$ de $\mathrm{Sc}_{2} \mathrm{O}_{3}, 1,1 \%$ de $\mathrm{CeO}_{2}$ e $90,9 \%$ de $\mathrm{ZrO}_{2}$. Esses resultados estão próximos da composição nominal fornecida pelo fabricante. No entanto, a análise por EDS é considerada semiquantitativa devido à ausência de padrão e curva de calibração. 
A Tabela I lista os valores de tamanho médio de grãos, determinados pelo método dos interceptos ${ }^{(57)}$, a densidade relativa determinada pelo método da imersão e a estrutura cristalina encontrada por difração de raios $X$ de amostras sinterizadas pelo método convencional. $O$ tamanho médio de grãos foi determinado apenas para amostras densas, com densidade relativa igual ou superior a $85 \%$. A intensidade (forte ou fraca) de fase secundária $(\beta)$ é indicada para cada condição de sinterização estudada. $O$ aumento da temperatura e do tempo promoveu o aumento exponencial do tamanho médio de grãos, como esperado. A $1070{ }^{\circ} \mathrm{C}$, o aumento do tempo de 10 para $15 \mathrm{~h}$ de patamar, apresentou pouca influência no aumento dos grãos. Porém, a quantidade de fase $\beta$ encontrada foi muito significativa (Figura 28). De outro modo, a $1200{ }^{\circ} \mathrm{C}$, o aumento do tempo favoreceu o crescimento de grãos, promoveu a efetiva densificação do material e a estabilização da fase cúbica.

Tabela I. Valores de densidade hidrostática relativa $\left(\rho_{H}\right)$, tamanho médio de grãos (G) e estrutura cristalina de amostras de ScCeSZ sinterizadas pelo método convencional.

\begin{tabular}{ccccc}
\hline \hline $\mathbf{T}\left({ }^{\circ} \mathbf{C}\right)$ & Tempo $(\mathbf{h})$ & $\boldsymbol{\rho}_{\boldsymbol{H}}(\%)$ & $\boldsymbol{G}(\boldsymbol{\mu m})$ & Estrutura $^{*}$ \\
\hline 1070 & 10 & $89,9 \pm 0,3$ & $0,30 \pm 0,03$ & $c+\beta_{\text {Forte }}$ \\
& 15 & $92,7 \pm 0,3$ & $0,32 \pm 0,05$ & $c+\beta_{\text {Forte }}$ \\
1200 & 0 & $75,0 \pm 0,3^{*}$ & $\sim 0,1^{* *}$ & $c+\beta_{\text {Fraca }}$ \\
& 0,2 & $90,4 \pm 0,3$ & $0,32 \pm 0,05$ & $c+\beta_{\text {Fraca }}$ \\
& 0,5 & $96,6 \pm 0,3$ & $0,53 \pm 0,06$ & $c+\beta_{\text {Fraca }}$ \\
& 0,7 & $96,7 \pm 0,3$ & $0,54 \pm 0,09$ & $c+\beta_{\text {Fraca }}$ \\
& 2 & $99,9 \pm 0,5$ & $0,67 \pm 0,12$ & $c$ \\
& 5 & $99,9 \pm 0,3$ & $0,70 \pm 0,13$ & $c$ \\
1250 & 15 & $99,7 \pm 0,5$ & $1,42 \pm 0,22$ & $c$ \\
& 0 & $85,4 \pm 0,4$ & $0,36 \pm 0,05$ & $c+\beta$ Fraca \\
1300 & 1 & $98,4 \pm 0,3$ & $0,73 \pm 0,14$ & $c$ \\
1350 & 0 & $93,2 \pm 0,8$ & $0,52 \pm 0,08$ & $c+\beta$ Fraca \\
1400 & 0 & $97,8 \pm 0,3$ & $0,91 \pm 0,17$ & $c$ \\
& 0 & $99,5 \pm 0,2$ & $1,51 \pm 0,29$ & $c$ \\
1500 & 1 & $99,3 \pm 0,5$ & $2,28 \pm 0,40$ & $c$ \\
\hline \hline
\end{tabular}

* Densidade geométrica relativa.

** Valor estimado pela micrografia da superfície de fratura.

- $c=$ cúbica, $\beta=$ romboédrica. 
Os resultados de tamanho médio de grãos obtidos para o material da Fuel Cell Materials estão de acordo com os resultados reportados para o ScCeSZ preparado por mistura de óxidos ${ }^{(31)}$ e produzido pela empresa DKKK ${ }^{(30)}$.

\section{Sinterização em Duas Etapas}

Com base nos estudos de sinterização pelo método convencional apresentados na seção anterior, diversos experimentos de sinterização em duas etapas foram realizados, variando a temperatura de pico $\left(T_{1}\right), T_{2}$ e tempo de patamar $\left(\mathrm{t}_{2}\right)$. Conforme mencionado anteriormente, $\mathrm{T}_{1}$ foi selecionada de acordo com a densidade relativa em torno de $75 \%$ da densidade teórica obtida após sinterização a $1200{ }^{\circ} \mathrm{C}$ por 0 h (Figura 23). No entanto, nessas condições, o ScCeSZ apresentou quantidade significativa de fase romboédrica (Figura 24). Dessa forma, para análise da influência de $T_{1}$ no processo de sinterização, principalmente, em relação à estrutura cristalina, avaliou-se também $T_{1}$ igual a $1250,1300,1350$ e $1400^{\circ} \mathrm{C}$

Os valores de densidade hidrostática e a estrutura cristalina encontrada para cada condição estudada são listados na Tabela II. O tamanho médio de grãos de algumas amostras também é apresentado. Para $T_{1}$ igual a $1200{ }^{\circ} \mathrm{C}$, o aumento de $\mathrm{T}_{2}$ (para $\mathrm{t}_{2}=5 \mathrm{~h}$ ) permite aumentar a densidade relativa de 77 para $90 \%$. A completa densificação do material foi alcançada utilizando-se $T_{1}$ maior que $1200{ }^{\circ} \mathrm{C}$ ou aumentando $t_{2}(>5 \mathrm{~h}$ ).

É importante ressaltar que para $\mathrm{T}_{1}$ menor que $1350{ }^{\circ} \mathrm{C}$ as amostras mesmo densas apresentam composição de fase (cúbica + romboédrica), exceto na condição $T_{1}$ igual a $1300{ }^{\circ} \mathrm{C}$ seguido de $T_{2}$ igual a $1200{ }^{\circ} \mathrm{C}$ por $5 \mathrm{~h}$.

O efeito do tempo $\left(t_{2}\right)$ no tamanho médio de grãos depende da temperatura $\mathrm{T}_{2}$. Assim, por exemplo, quando $\mathrm{T}_{2}$ igual a $1070{ }^{\circ} \mathrm{C}$ o aumento de $\mathrm{t}_{2}(5,10$ e $15 \mathrm{~h})$ revela que não há variação significativa no tamanho médio de grãos. Este resultado está de acordo com a premissa da técnica de sinterização em duas etapas onde ocorre densificação sem crescimento de grão no segundo estágio de sinterização. Entretanto, quando $\mathrm{T}_{2}$ igual a $1100{ }^{\circ} \mathrm{C}, \mathrm{G}$ aumenta de $\sim 0,3$ para $\sim 0,45 \mu \mathrm{m}$ com o aumento de $t_{2}$. Este resultado também está de acordo com o método de sinterização proposto por Wang ${ }^{(43)}$, onde há uma região específica, denominada janela cinética (kinectic window), na qual não ocorre o crescimento de grão, mas fora desta faixa pode ocorrer o crescimento de grãos ou não 
acontecer a densificação. Quando $\mathrm{T}_{1}$ é igual ou superior a $1350{ }^{\circ} \mathrm{C}$, independentemente de $T_{2}$ e $t_{2}$, a estrutura cristalina resultante é sempre cúbica. Nesta situação, o tamanho médio de grãos aumenta tanto com a temperatura $\left(\mathrm{T}_{2}\right)$ quanto com o tempo $\left(\mathrm{t}_{2}\right)$.

Tabela II. Valores de densidade hidrostática relativa $\left(\rho_{H}\right)$, tamanho médio de grãos $(G)$ e estrutura cristalina de amostras de ScCeSZ sinterizadas em duas etapas.

\begin{tabular}{llcccc}
\hline \hline $\mathbf{T}_{\mathbf{1}}\left({ }^{\circ} \mathbf{C}\right)$ & $\mathbf{T}_{\mathbf{2}}\left({ }^{\circ} \mathbf{C}\right)$ & $\mathbf{t}_{\mathbf{2}}(\mathbf{h})$ & $\boldsymbol{\rho}_{\boldsymbol{H}}(\%)$ & $\boldsymbol{G}(\boldsymbol{\mu m})$ & Estrutura \\
\hline 1200 & 1000 & 5 & $76,7 \pm 0,25^{*}$ & - & $c+\beta_{\text {Forte }}$ \\
& 1050 & 5 & $82,1 \pm 0,42^{*}$ & - & $c+\beta$ Forte \\
& 1070 & 5 & $88,3 \pm 0,47$ & $0,24 \pm 0,03$ & $c+\beta$ Forte \\
1200 & 1100 & 5 & $89,7 \pm 0,49$ & $0,29 \pm 0,04$ & $c+\beta$ Forte \\
& 1070 & 10 & $99,0 \pm 0,23$ & $0,25 \pm 0,05$ & $c+\beta_{\text {Forte }}$ \\
1200 & 1100 & 10 & $98,0 \pm 0,21$ & $0,35 \pm 0,05$ & $c+\beta$ Forte \\
& 1070 & 15 & $98,4 \pm 0,31$ & $0,28 \pm 0,05$ & $c+\beta$ Forte \\
1250 & 1100 & 15 & $99,9 \pm 0,39$ & $0,44 \pm 0,12$ & $c+\beta$ Forte \\
& 1070 & 15 & $98,3 \pm 0,44$ & - & $c+\beta$ Forte \\
1300 & 1100 & 15 & $94,0 \pm 0,30$ & - & $c+\beta$ Forte \\
& 1200 & 5 & $99,4 \pm 0,19$ & - & $c+\beta$ Fraca \\
1300 & 1070 & 5 & $99,9 \pm 0,53$ & $0,79 \pm 0,17$ & $c$ \\
& 1100 & 10 & $98,6 \pm 0,18$ & - & $c+\beta$ Fraca \\
1300 & 1100 & 15 & $95,0 \pm 0,35$ & - & $c+\beta$ Fraca \\
1350 & 1200 & 2 & $99,8 \pm 0,20$ & - & $c+\beta$ Fraca \\
1350 & 1200 & 5 & $99,9 \pm 0,24$ & $0,74 \pm 0,14$ & $c$ \\
1400 & 1200 & 2 & $99,9 \pm 0,22$ & $1,27 \pm 0,23$ & $c$ \\
1400 & 1100 & 5 & $99,3 \pm 0,27$ & $1,12 \pm 0,14$ & $c$ \\
& 1200 & 5 & $99,9 \pm 0,27$ & $1,08 \pm 0,19$ & $c$ \\
1400 & 1100 & 10 & $98,6 \pm 0,23$ & - & $c$ \\
\hline \hline
\end{tabular}

* Densidade geométrica relativa.

- $c=$ cúbica, $\beta=$ romboédrica.

A Figura 32 mostra as curvas de tamanho médio de grãos em função da densidade relativa para amostras sinterizadas pelo método convencional (símbolo cheio), em tempo de patamar nulo, e para algumas condições em duas etapas (símbolo vazio). Conforme apresentado anteriormente na Tabela I (sinterização convencional), a completa densificação é alcançada a $1400^{\circ} \mathrm{C}$, onde $G$ é igual a 1,51 $\mu \mathrm{m}$. Contudo, pode-se observar que através da sinterização em duas etapas é possível suprimir ao menos parcialmente o crescimento de grãos. 


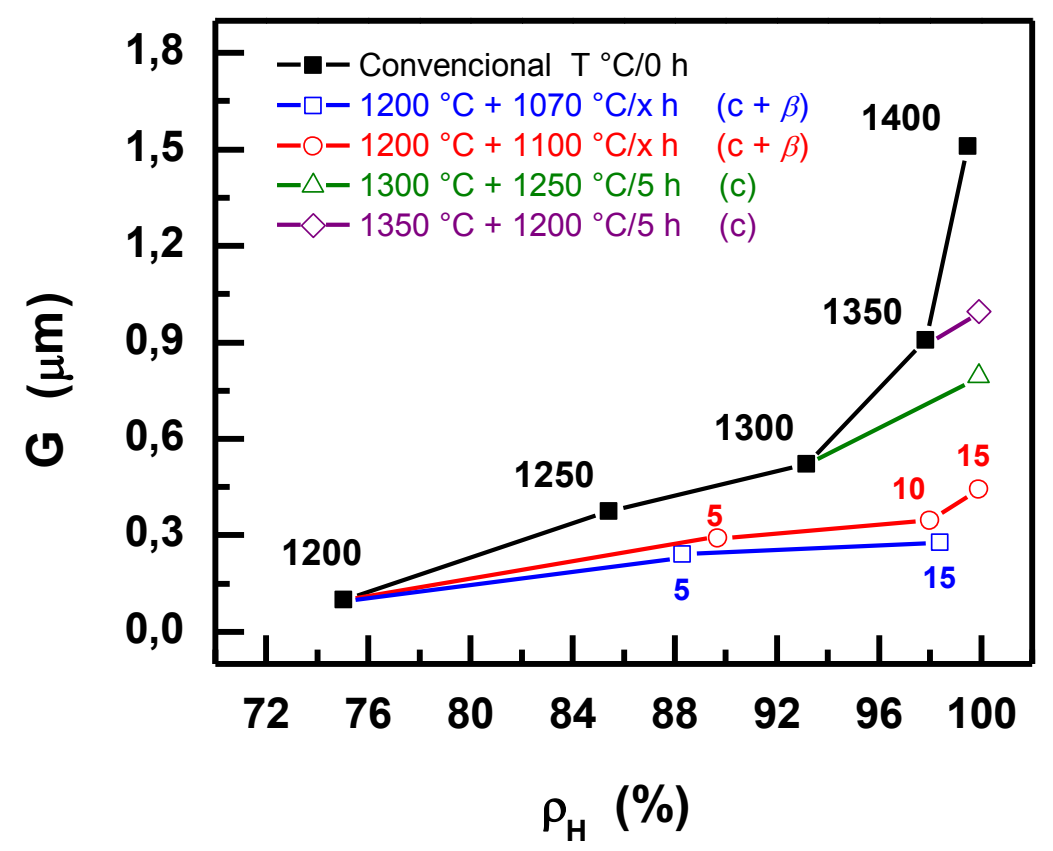

Figura 32. Tamanho médio de grãos em função da densidade hidrostática relativa de amostras sinterizadas pelos métodos convencional e duas etapas.

A Figura 33 mostra os difratogramas de raios $X$ de amostras sinterizadas pelo método de duas etapas. Para as condições de sinterização analisadas considerando $T_{1}$ igual a $1200{ }^{\circ} \mathrm{C}$ observa-se pelo aumento da intensidade dos picos nos difratogramas de raios $\mathrm{X}$ que $\mathrm{o}$ aumento do tempo de patamar favorece a formação da fase romboédrica. No entanto, o aumento de $T_{1}$ promoveu a predominância de uma estrutura cúbica com pequena quantidade da fase secundária $\beta$, sendo que o material cúbico foi obtido apenas para $T_{1}$ superior a $1300{ }^{\circ} \mathrm{C}$. Isso mostra que $T_{1}$ é determinante para a obtenção de um material monofásico. 


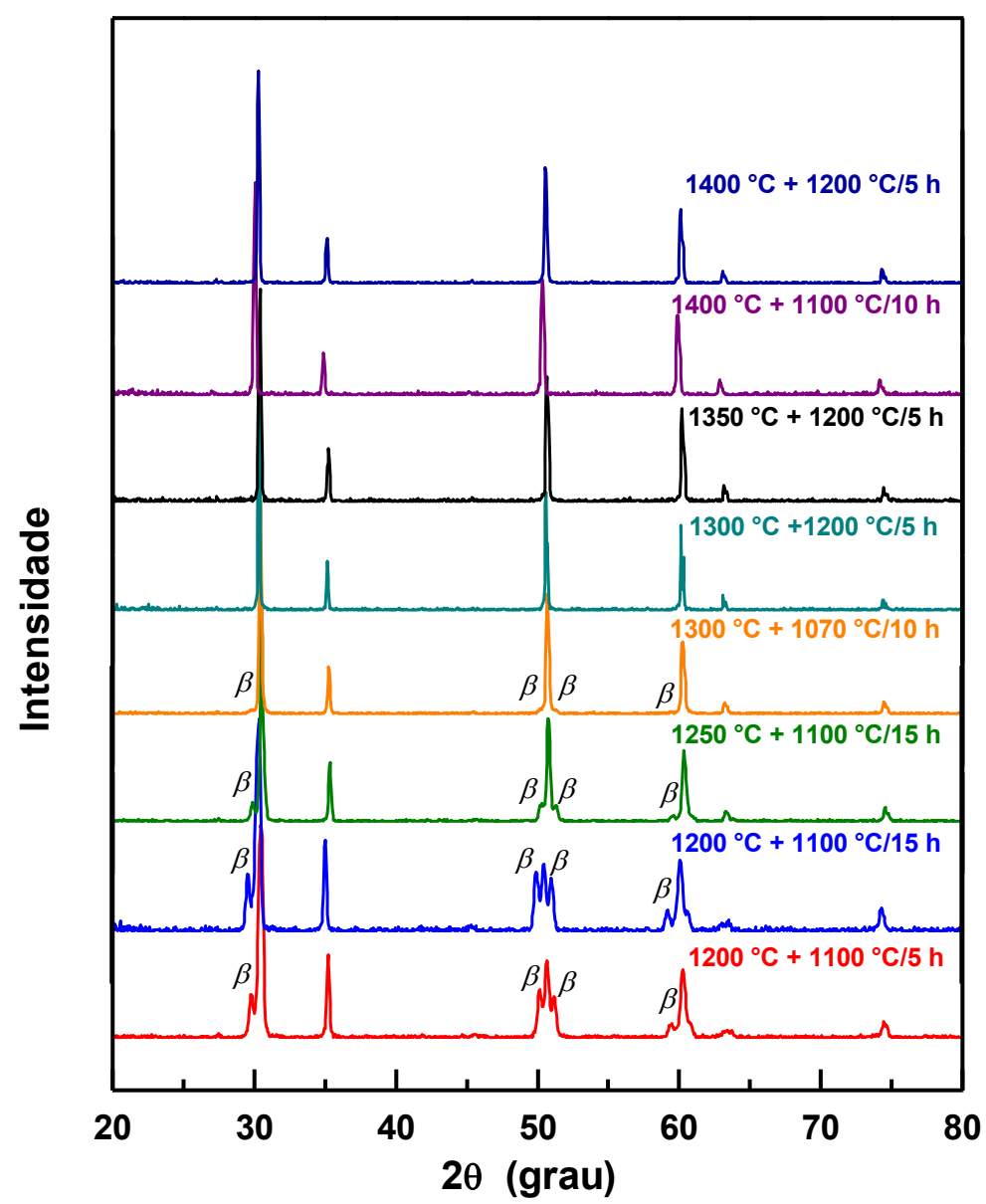

Figura 33. Difratogramas de raios $X$ de amostras de ScCeSZ sinterizadas pelo método de duas etapas.

A Figura 34 mostra micrografias obtidas em microscópio eletrônico de varredura de amostras sinterizadas em duas etapas mantendo $T_{1}$ igual a $1200^{\circ} \mathrm{C}$ e variando $T_{2}$ e $t_{2}$. $O$ aumento da temperatura $\left(T_{2}\right)$ e do tempo de patamar promoveu a efetiva densificação e aumento da homogeneidade microestrutural. Um ligeiro aumento do tamanho médio de grãos pode ser observado com o aumento de $t_{2}$. 


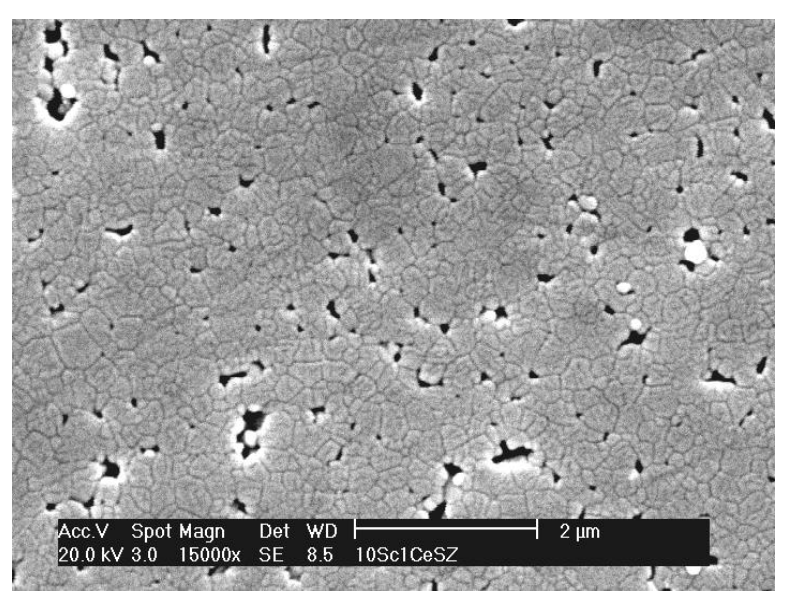

(a) $1200^{\circ} \mathrm{C}+1070^{\circ} \mathrm{C} / 5 \mathrm{~h}$

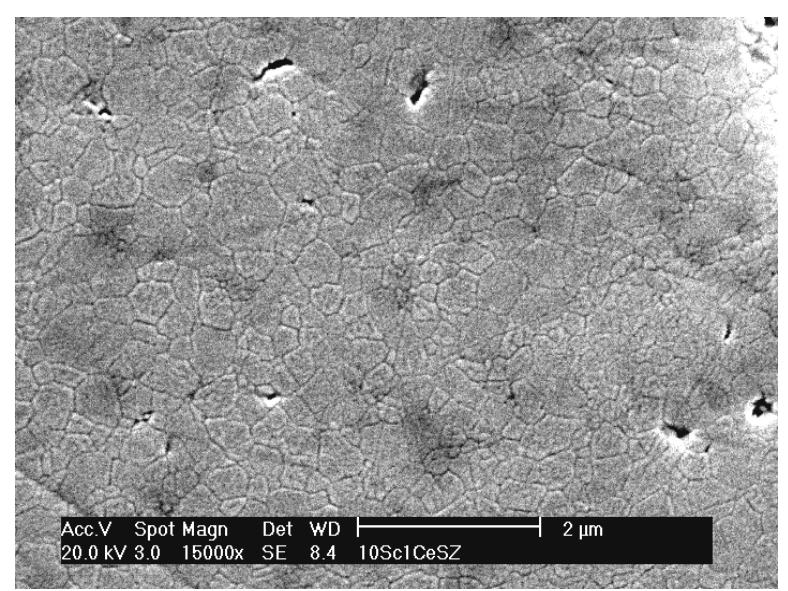

(c) $1200^{\circ} \mathrm{C}+1100^{\circ} \mathrm{C} / 10 \mathrm{~h}$

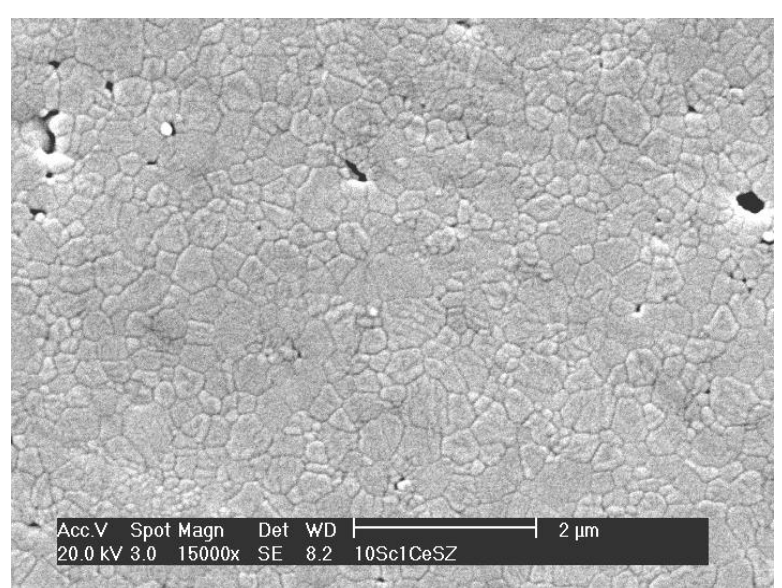

(b) $1200^{\circ} \mathrm{C}+1100^{\circ} \mathrm{C} / 5 \mathrm{~h}$

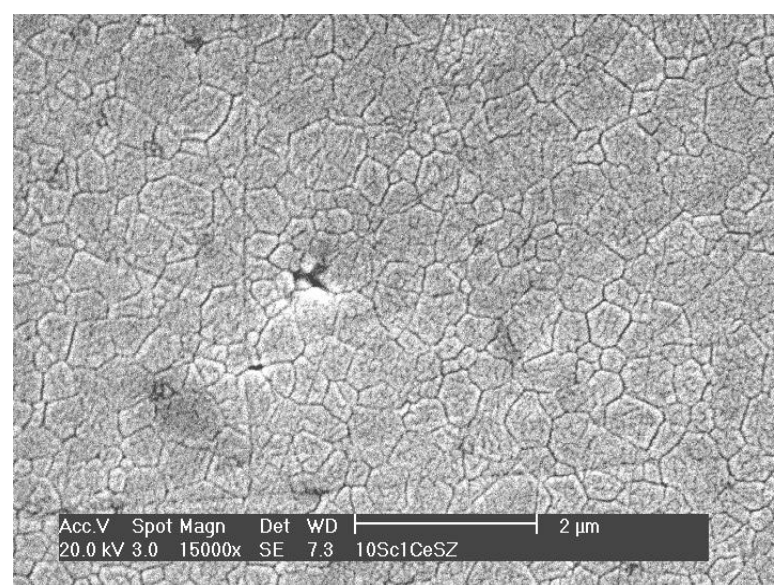

(d) $1200^{\circ} \mathrm{C}+1100^{\circ} \mathrm{C} / 15 \mathrm{~h}$

Figura 34. Micrografias de amostras de ScCeSZ sinterizadas em duas etapas: (a) $1200{ }^{\circ} \mathrm{C}+1070{ }^{\circ} \mathrm{C} / 5 \mathrm{~h}$, (b) $1200{ }^{\circ} \mathrm{C}+1100{ }^{\circ} \mathrm{C} / 5 \mathrm{~h}$, (c) $1200^{\circ} \mathrm{C}+1100^{\circ} \mathrm{C} / 10 \mathrm{~h} \mathrm{e} \mathrm{(d)} 1200^{\circ} \mathrm{C}+1100^{\circ} \mathrm{C} / 15 \mathrm{~h}$.

Pode-se observar que na condição de $1200{ }^{\circ} \mathrm{C}+1070{ }^{\circ} \mathrm{C} / 5 \mathrm{~h}$ (Figura 34a) ainda há poros no material e a microestrutura apresentou-se mais homogênea em relação ao método convencional $\left(1200^{\circ} \mathrm{C}\right.$ por $0,2 \mathrm{~h}$, Figura 30a).

A Figura 35 mostra micrografias obtidas em MEV onde $T_{2}$ e $t_{2}$ são fixos. 


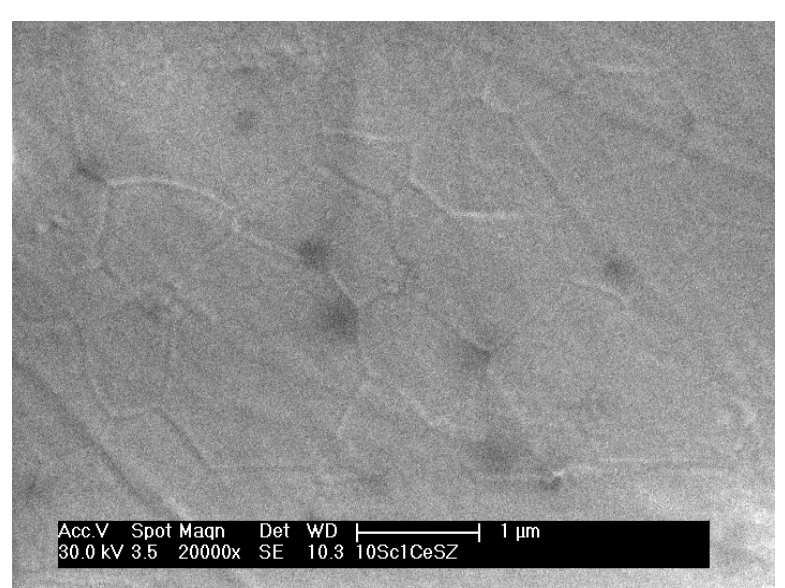

(a) $1350^{\circ} \mathrm{C}+1200^{\circ} \mathrm{C} / 5 \mathrm{~h}$

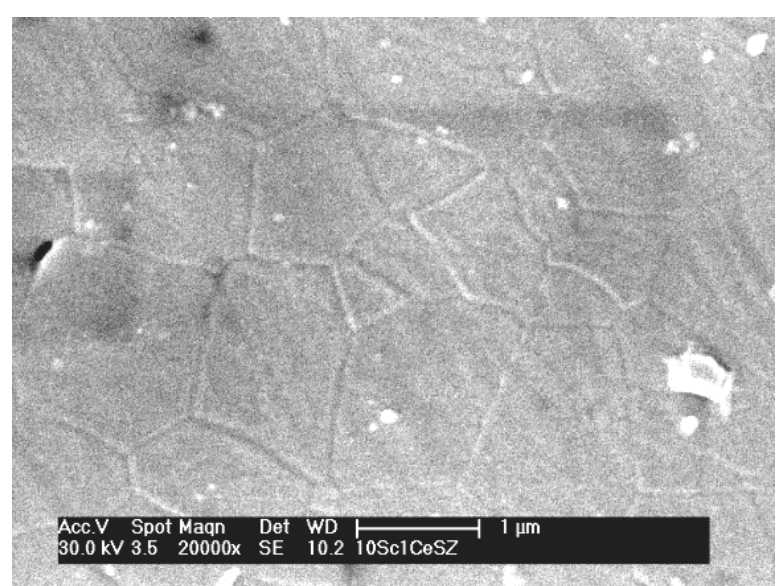

(b) $1400^{\circ} \mathrm{C}+1200^{\circ} \mathrm{C} / 5 \mathrm{~h}$

Figura 35. Micrografias de amostras de ScCeSZ sinterizadas em duas etapas: (a) $1350^{\circ} \mathrm{C}+1200{ }^{\circ} \mathrm{C} / 5 \mathrm{~h}$, (b) $1400{ }^{\circ} \mathrm{C}+1200^{\circ} \mathrm{C} / 5 \mathrm{~h}$.

As amostras sinterizadas a 1350 e $1400{ }^{\circ} \mathrm{C}$ mantendo fixos $T_{2}$ igual a $1200{ }^{\circ} \mathrm{C}$ e t $t_{2}$ igual a $5 \mathrm{~h}$ apresentaram grãos da ordem de $1 \mu \mathrm{m}$, a metade do tamanho médio de grãos das amostras sinterizadas a $1400^{\circ} \mathrm{C}$ por $1 \mathrm{~h}$ (Tabela I). No método de sinterização em duas etapas o tamanho médio de grãos é determinado pela temperatura de pico $\left(T_{1}\right)$, dentro da janela cinética.

Alguns autores demonstraram que pode haver a formação de fases secundárias apenas na superfície do ScCeSZ ${ }^{(35)}$. Dessa forma, com o objetivo de avaliar se a fase romboédrica forma-se apenas na superfície do material, realizou-se o desbaste de uma das faces de uma amostra sinterizada pelo método de duas etapas, a qual apresentou uma fase romboédrica intensa. Os difratogramas de raios $\mathrm{X}$ da amostra sinterizada a $1200{ }^{\circ} \mathrm{C}+1100{ }^{\circ} \mathrm{C} / 15 \mathrm{~h}$ desbastada duas vezes são mostrados na Figura 36 . As espessuras da amostra antes $(2,487 \mathrm{~mm})$ e após desbastes consecutivos $(2,395$ e 2,284 mm) estão indicadas em seus respectivos difratogramas. 


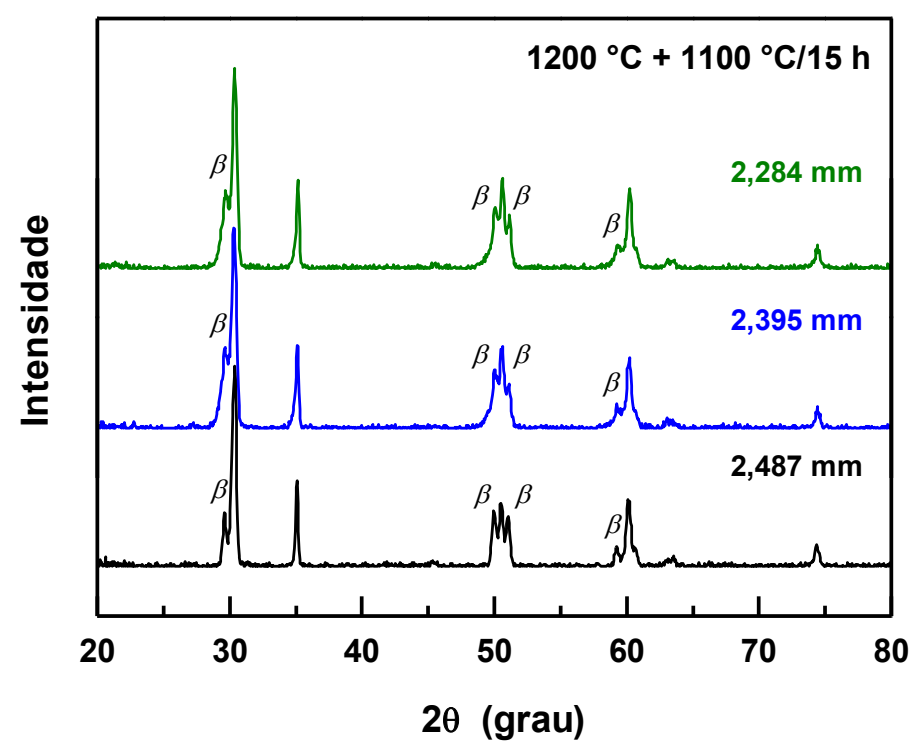

Figura 36. Difratogramas de raios $X$ de várias camadas da amostra de ScCeSZ sinterizada em duas etapas.

Este resultado mostra que a fase romboédrica permanece em todo o volume do material.

\section{Sinterização Assistida por Campo Elétrico}

A Tabela III lista as condições estudadas por sinterização assistida por campo elétrico e as densidades hidrostáticas relativas das amostras. Os experimentos foram realizados variando a temperatura e o tempo de patamar. A temperatura foi selecionada com base nos resultados de dilatometria, enquanto que, o tempo de patamar foi selecionado de acordo com o reportado na literatura para a zircônia-escândia ${ }^{(18,51)}$. Após sinterização, as amostras apresentaram-se densas, com densidade relativa maior que $95 \%$. Apenas a amostra sinterizada a $1000{ }^{\circ} \mathrm{C}$ por 5 min apresentou baixa densidade, aproximadamente $74 \%$. Devido ao rápido aquecimento e à pressão aplicada pela sinterização por SPS foi possível obter elevados valores de densidade em temperaturas mais baixas em relação ao processo convencional. 
Tabela III. Condições de sinterização por SPS e densidade hidrostática relativa $\left(\rho_{H}\right)$ das amostras.

\begin{tabular}{lcccc}
\hline \hline $\mathbf{T}\left({ }^{\circ} \mathbf{C}\right)$ & $\begin{array}{c}\text { Tempo } \\
(\mathbf{m i n})\end{array}$ & $\begin{array}{c}\text { Pressão } \\
(\mathbf{M P a})\end{array}$ & $\begin{array}{c}\text { Taxa de Aquecimento } \\
\left({ }^{\circ} \mathbf{C} / \mathbf{m i n}\right)\end{array}$ & $\boldsymbol{\rho}_{\boldsymbol{H}}(\%)$ \\
\hline 1000 & 5 & 65 & 100 & $74,3 \pm 0,2^{*}$ \\
1100 & 5 & 65 & 100 & $95,7 \pm 0,1$ \\
1200 & 1 & 65 & 100 & $96,5 \pm 0,1$ \\
1200 & 5 & 65 & 100 & $97,1 \pm 0,1$ \\
\hline \hline
\end{tabular}

* Densidade geométrica relativa.

A fotografia das amostras sinterizadas por SPS é mostrada na Figura 37. Com exceção da amostra sinterizada a $1000{ }^{\circ} \mathrm{C}$ por 5 min, todas as demais apresentaram coloração escura. Essa coloração com tons de marrom, cinza e preto são provenientes da contaminação por carbono (molde) ou da redução do $\mathrm{Ce}^{4+}$ para $\mathrm{Ce}^{3+}$, devido à atmosfera redutora durante o experimento ${ }^{(31,32)}$. As folhas de grafita utilizadas para proteger o molde e facilitar a extração da amostra sinterizada podem promover a difusão de carbono na amostra em altas temperaturas durante o processo de sinterização. Além disso, alguns autores demonstraram que a redução do cério promove a coloração marrom em amostras de ScCeSZ ${ }^{(31,32)}$.

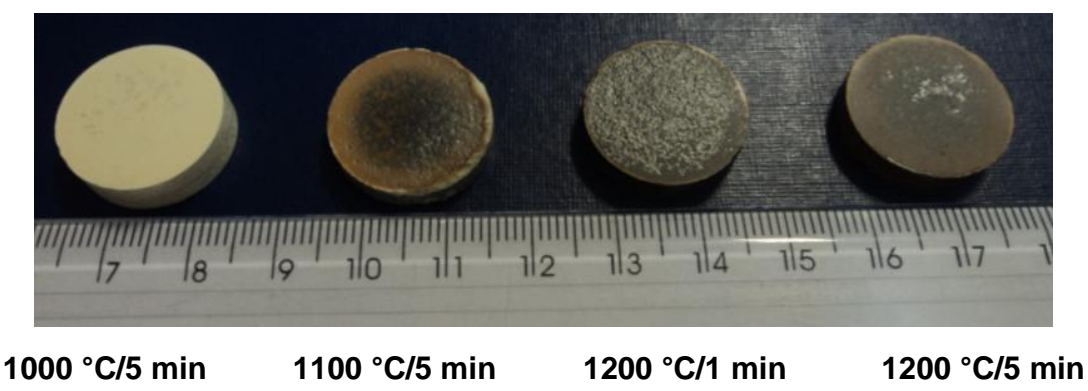

Figura 37. Fotografia das amostras sinterizadas por SPS.

A Figura 38 mostra a fotografia das amostras cortadas. Pode-se observar que a difusão de carbono ocorreu por toda a amostra (Figura 38a). Para a caracterização do material utilizou-se as amostras apresentadas na Figura 38b. 


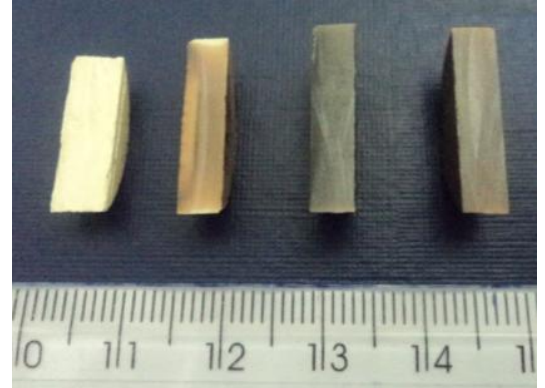

(a)

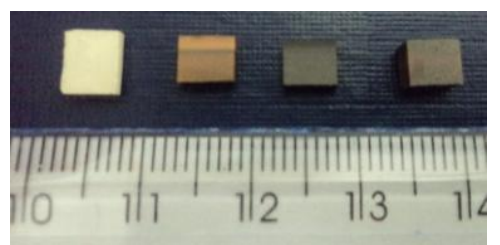

(b)

Figura 38. Fotografias das amostras sinterizadas por SPS cortadas. (a) Após primeiro corte e (b) amostras cortadas para caracterização.

A Figura 39 mostra os difratogramas de raios $X$ das amostras sinterizadas por SPS antes (Figura 39a) e após desbaste (Figura 39b). Os resultados de difração de raios $X$ são característicos da fase cúbica para todas as condições estudadas. O ligeiro alargamento, na Figura 39a, observado na região de baixo ângulo do pico de maior intensidade para as amostras de 1000 e $1100^{\circ} \mathrm{C}$ pode estar relacionado com o pequeno tamanho de cristalito. Após o desbaste de aproximadamente $50 \mu \mathrm{m}$, os difratogramas são similares aos anteriores ao desbaste, exceto pelo alargamento maior na região de baixo ângulo do pico de difração mais intenso. Esse alargamento provavelmente não está relacionado com a fase romboédrica, uma vez que alguns autores reportaram a eliminação desta fase e estabilização da fase cúbica à temperatura ambiente na zircônia-escândia submetida a resfriamento rápido (quenching) ${ }^{(23)}$.
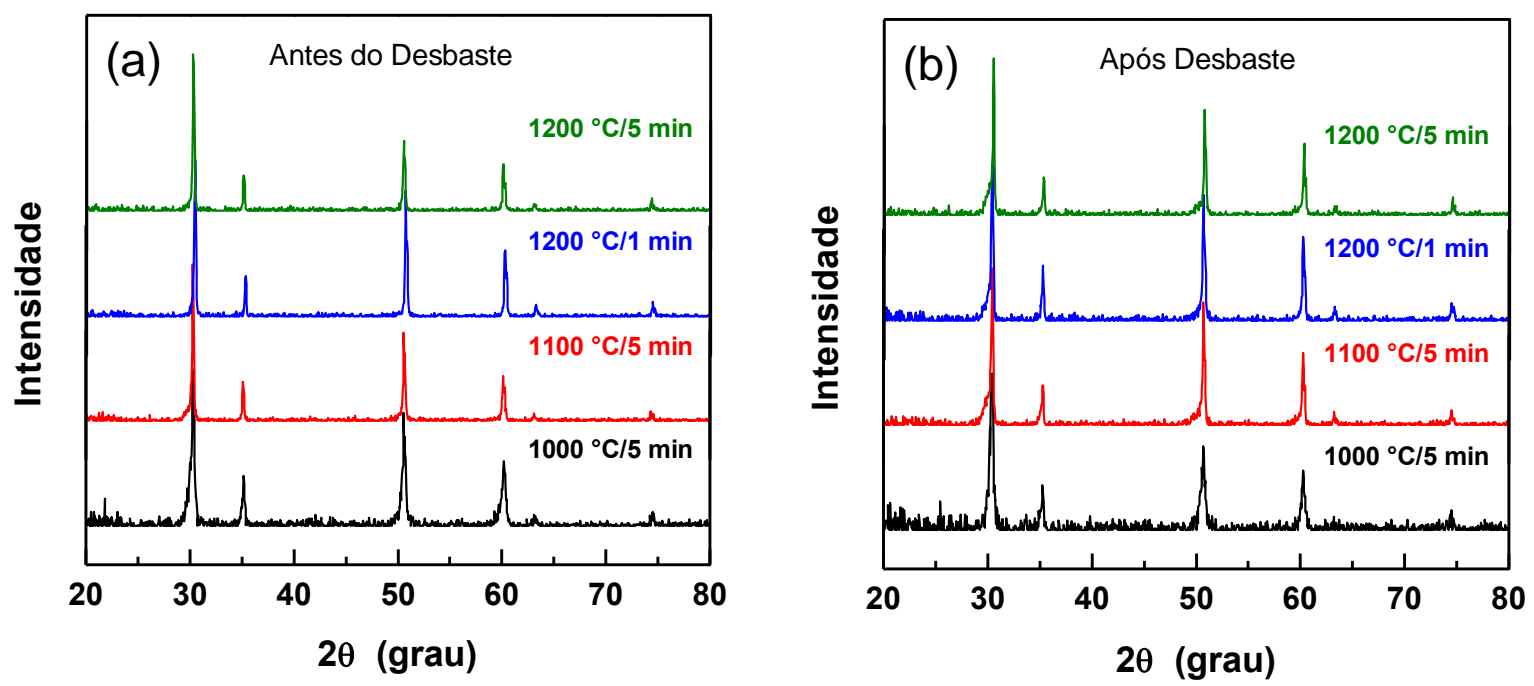

Figura 39. Difratogramas de raios $X$ das amostras de ScCeSZ sinterizadas por SPS (a) antes do desbaste e (b) após desbaste. 
Assim como o resfriamento, o aquecimento rápido pode provocar alterações na estrutura dos materiais. Para verificar a possibilidade de formação de fases secundárias, realizou-se análise por espectroscopia Raman. Esta técnica é muito utilizada para investigar a composição de fases na zircônia-escândia ${ }^{(10)}$. Os modos vibracionais são fortemente dependentes da estrutura cristalina e da composição dos materiais, dessa forma, é possível a determinação de fases não detectáveis por difração de raios $X^{(29)}$.

A Figura 40 mostra os espectros Raman das amostras sinterizadas por SPS nas temperaturas de 1100 e $1200^{\circ} \mathrm{C}$. Todas as amostras apresentaram uma banda intensa a $620 \mathrm{~cm}^{-1}$, a qual é atribuída à fase cúbica ${ }^{(72,15,24,29)}$. A banda observada a $480 \mathrm{~cm}^{-1}$ é característica da fase tetragonal metaestável $\left(t^{\prime}\right)^{(15,24,29)}$. $\mathrm{Na}$ amostra sinterizada a $1200{ }^{\circ} \mathrm{C}$ por 1 min é observada com maior evidência uma banda na região de $700 \mathrm{~cm}^{-1}$, denotada pelo asterisco. Essa banda foi detectada na zircônia-escândia contendo a fase tetragonal, e foi atribuída a um tipo de desordem decorrente da substituição $\mathrm{Sc}^{3+}$ - cátion dopante e consequente formação de vacância de oxigênio ${ }^{(10)}$.

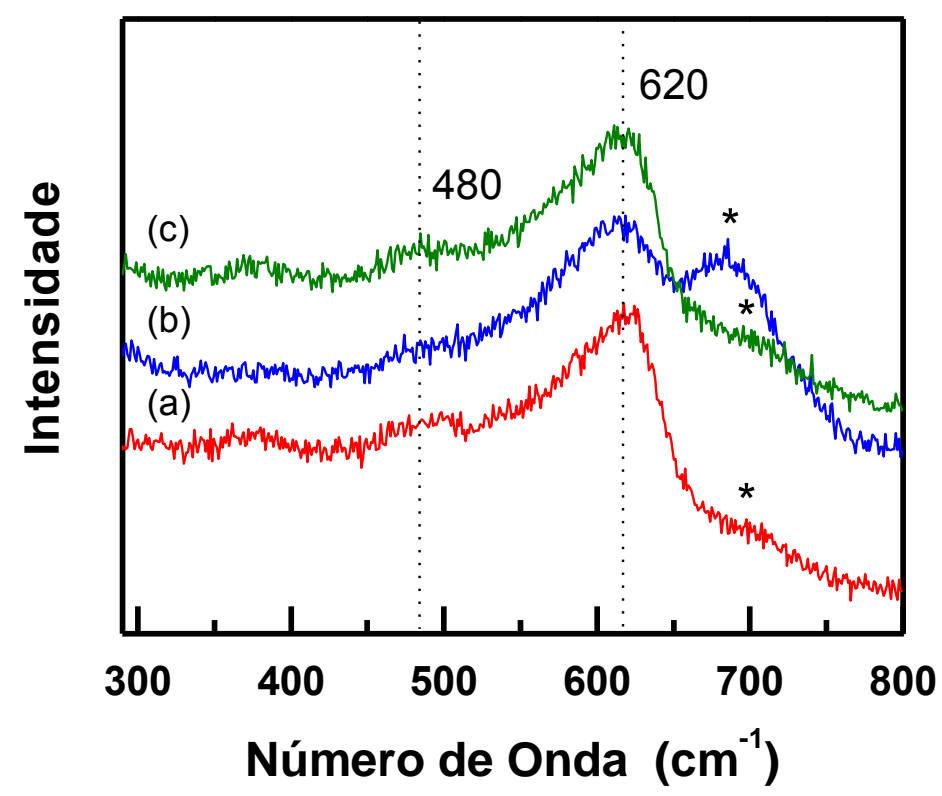

Figura 40. Espectro Raman das amostras sinterizadas por SPS. (a) $1100^{\circ} \mathrm{C} / 5 \mathrm{~min}$, (b) $1200^{\circ} \mathrm{C} / 1 \mathrm{~min}$ e (c) $1200^{\circ} \mathrm{C} / 5 \mathrm{~min}$. 
Este resultado mostrou que 0 alargamento nos difratogramas de raios $X$ (Figura 39) está relacionado com a fase tetragonal. Dessa forma, a sinterização assistida por campo elétrico favorece a formação da fase tetragonal ainda que em pequena concentração.

As amostras que apresentaram coloração escura após sinterização foram submetidas a tratamento térmico a $900^{\circ} \mathrm{C}$ por $4 \mathrm{~h}$ para eliminação de carbono e reoxidação do $\mathrm{Ce}^{3+}$ para $\mathrm{Ce}^{4+}$. Após tratamento, as amostras apresentaram-se ligeiramente mais claras. No entanto, houve formação da fase romboédrica, como pode ser observado nos difratogramas de raios $X$ na Figura 41. Por outro lado, o material sinterizado pelo processo convencional permaneceu cúbico monofásico após tratamento térmico nas mesmas condições. A fase romboédrica diminui a condutividade elétrica do material ${ }^{(9)}$. Portanto, embora seja possível eliminar alguma quantidade de carbono por meio do tratamento térmico realizado ao ar, o processo prejudica as propriedades elétricas do material, uma vez que favorece a formação da fase secundária $\beta$.

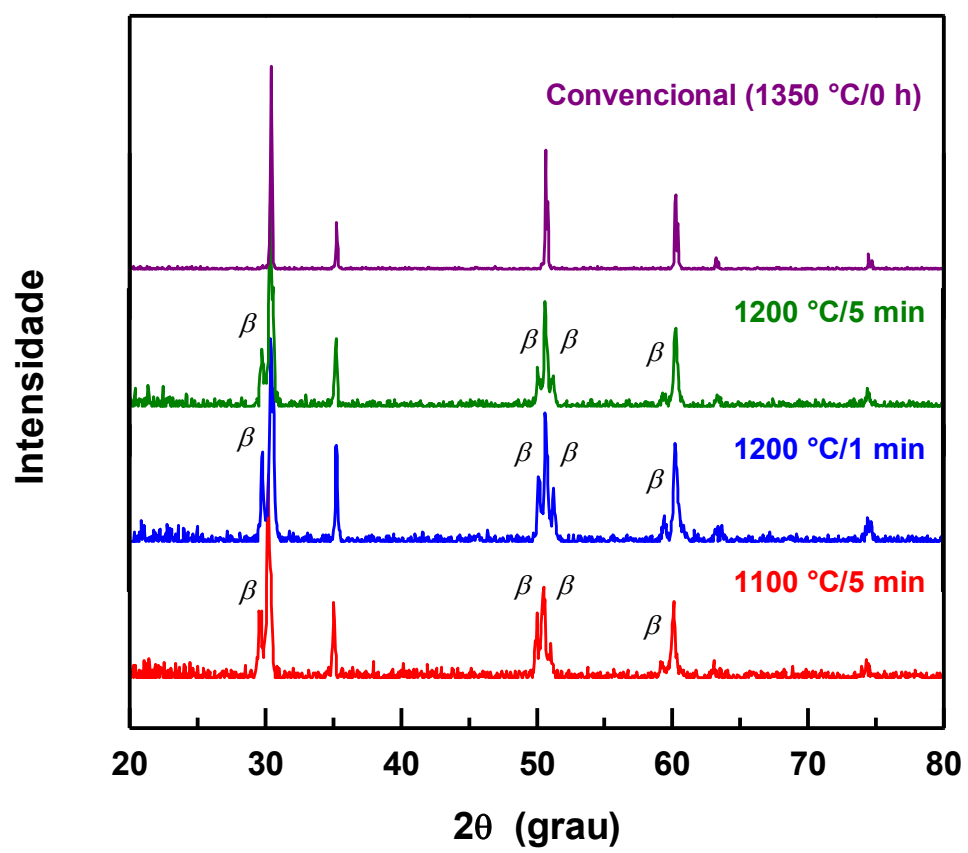

Figura 41. Difratogramas de raios $X$ das amostras de ScCeSZ sinterizadas por SPS e método convencional após serem submetidas a tratamento térmico a $900{ }^{\circ} \mathrm{C}$ por $4 \mathrm{~h}$. 
A Figura 42 mostra as micrografias das amostras sinterizadas por SPS obtidas por FEG. Observa-se, na Figura 42a, a imagem da superfície de fratura da amostra sinterizada a $1000{ }^{\circ} \mathrm{C}$ por $5 \mathrm{~min}$. Assim como observado na micrografia da superfície de fratura da amostra sinterizada pelo método convencional (Figura 29), a porosidade está distribuída aleatoriamente. Para essa condição, o tamanho médio de grãos foi estimado em aproximadamente $0,1 \mu \mathrm{m}$. As micrografias das amostras, sinterizadas a 1100 e $1200^{\circ} \mathrm{C}$, polidas e atacadas termicamente são apresentadas nas Figuras 42b, 42c e 42d. O aumento da temperatura e do tempo de patamar promoveu um ligeiro aumento da homogeneidade e tamanho dos grãos. O tamanho médio dos grãos para cada condição é apresentado na Tabela IV. A falta de homogeneidade microestrutural observada em algumas amostras de ScCeSZ independente do processo de sinterização empregado pode ser explicada com base nas características do pó, o qual é basicamente constituído por aglomerados de diferentes tamanhos, como pôde ser observado nas micrografias da Figura 19. Dessa forma, a rápida sinterização por SPS a $1100{ }^{\circ} \mathrm{C}$ por 5 min e $1200{ }^{\circ} \mathrm{C}$ por 1 min promoveu a densificação do material com baixa uniformidade microestrutural em relação ao tamanho e à distribuição dos grãos. 


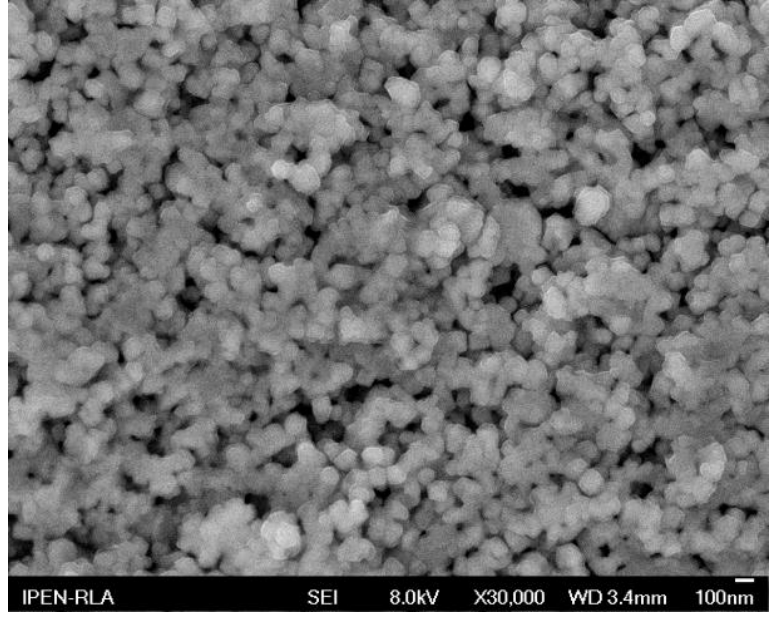

(a) $1000^{\circ} \mathrm{C} / 5 \mathrm{~min}$

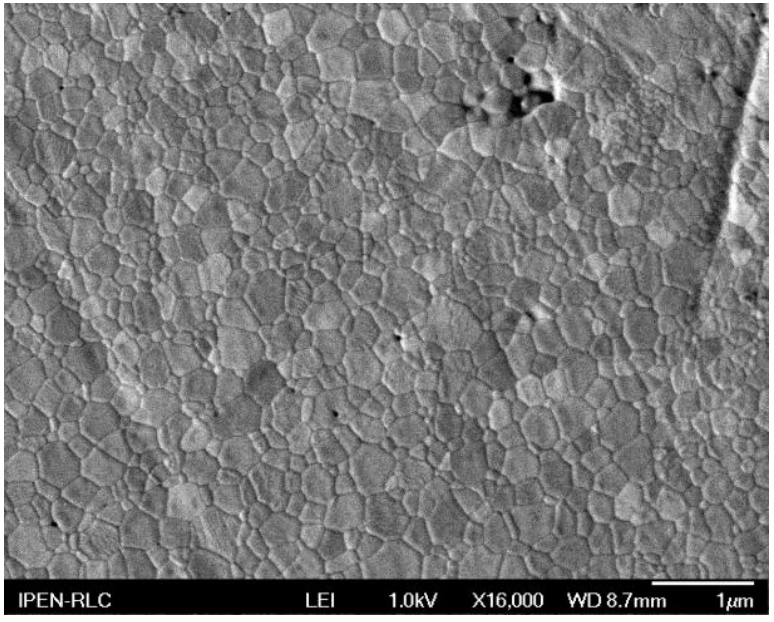

(c) $1200^{\circ} \mathrm{C} / 1 \mathrm{~min}$

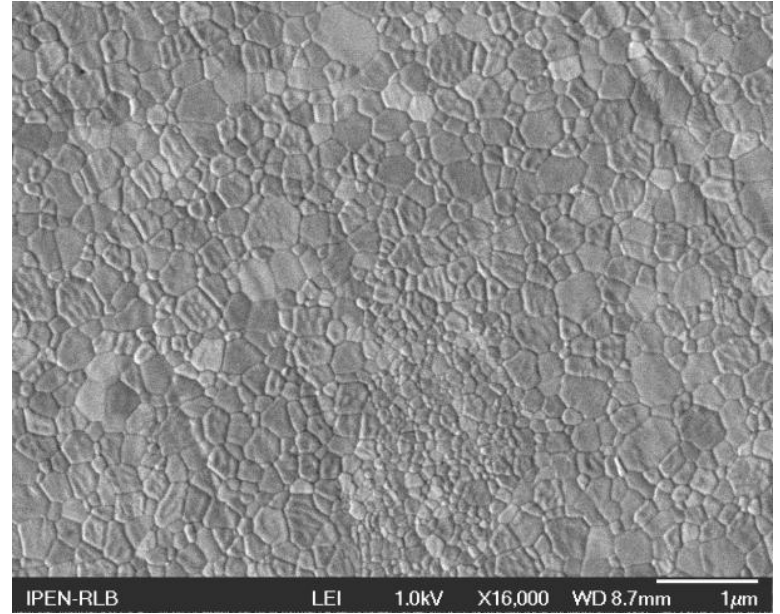

(b) $1100^{\circ} \mathrm{C} / 5 \mathrm{~min}$

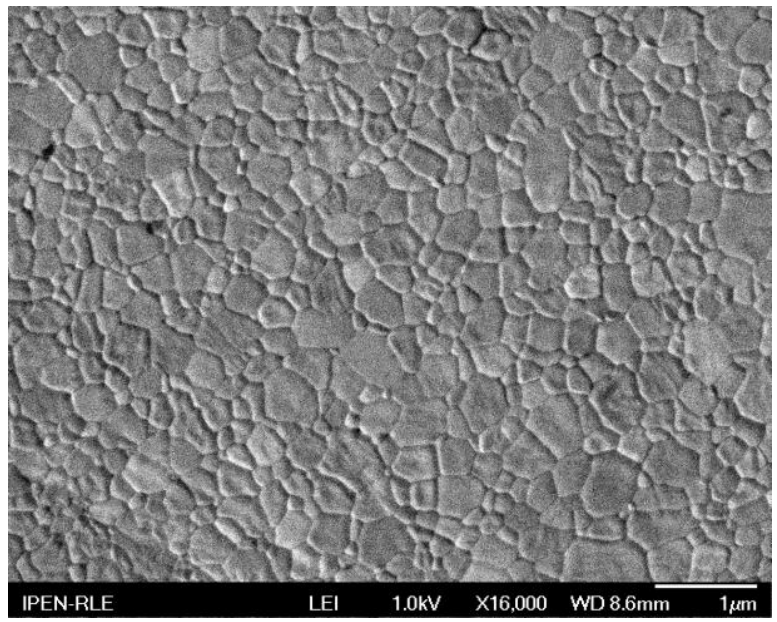

(d) $1200^{\circ} \mathrm{C} / 5 \mathrm{~min}$

Figura 42. Micrografias de amostras de ScCeSZ sinterizadas por SPS: (a) $1000{ }^{\circ} \mathrm{C}$ por 5 min (fratura), (b) $1100{ }^{\circ} \mathrm{C}$ por $5 \mathrm{~min}$, (c) $1200{ }^{\circ} \mathrm{C}$ por $1 \mathrm{~min}$ e (d) $1200^{\circ} \mathrm{C}$ por $5 \mathrm{~min}$.

Tabela IV. Tamanho médio de grãos $(G)$ das amostras sinterizadas por SPS.

\begin{tabular}{ccc}
\hline \hline $\mathbf{T}\left({ }^{\circ} \mathbf{C}\right)$ & Tempo (min) & $\boldsymbol{G}(\boldsymbol{\mu m})$ \\
\hline 1000 & 5 & $\sim 0,1^{*}$ \\
1100 & 5 & $0,31 \pm 0,03$ \\
1200 & 1 & $0,36 \pm 0,04$ \\
1200 & 5 & $0,42 \pm 0,05$ \\
\hline \hline
\end{tabular}

* Valor estimado pela micrografia da amostra fraturada. 
O tamanho médio dos grãos das amostras sinterizadas a partir de $1100{ }^{\circ} \mathrm{C}$ apresentaram-se muito semelhantes considerando as incertezas relativas. Em comparação com o método convencional de sinterização, os valores de $G$ encontrados são similares aos observados em amostras sinterizadas a $1200{ }^{\circ} \mathrm{C}$ por $0,2 \mathrm{~h}$ (12 $\mathrm{min}$ ), as quais apresentaram densidades relativas mais baixas, cerca de $90 \%$ (Tabela I). Enquanto que, em amostras com densidades semelhantes (aproximadamente 96\%) o tamanho médio de grãos chegou a $0,5 \mu \mathrm{m}$, após sinterização a $1200^{\circ} \mathrm{C}$ por $0,5 \mathrm{~h}$.

Em relação à sinterização em duas etapas, os tamanhos médios de grãos obtidos após sinterização assistida por campo elétrico são similares, considerando amostras com densidades superiores a 95\%. Esses resultados confirmam que a sinterização em duas etapas é efetiva em relação à supressão parcial do crescimento de grãos para o ScCeSZ, sendo compatível com técnicas mais sofisticadas como a sinterização assistida por campo elétrico em relação à elevada densificação do material com tamanho médio de grãos reduzidos. No entanto, há uma grande limitação na utilização da sinterização em duas etapas devido à formação da fase secundária romboédrica, a qual é eliminada, principalmente, com o aumento da temperatura de pico $T_{1}$ que apresenta forte influência no tamanho dos grãos. O menor valor de $G$ encontrado para o material monofásico pelo método de duas etapas foi o dobro dos tamanhos médios de grãos obtidos por SPS.

Apesar das vantagens mencionadas acima da sinterização assistida por campo elétrico esta favorece a formação da fase tetragonal que também pode influenciar a condutividade elétrica. 


\section{Condutividade Elétrica}

A condutividade elétrica de amostras densas $\left(\rho_{H}>95 \%\right)$ sinterizadas pelos três métodos em estudo foi analisada por meio da técnica de espectroscopia de impedância ${ }^{(67,68,73)}$. Essa técnica permite em muitos casos separar a contribuição do grão e contorno de grão para a resposta elétrica de materiais policristalinos. Conforme mencionado no Capítulo 2 , os dados de impedância, $Z^{*}(\omega)$, geralmente são representados no plano complexo ou diagrama de impedância, que consiste em apresentar o oposto da parte imaginária, $-Z^{\prime}(\omega)$, em função da parte real, $Z(\omega)$, para cada frequência medida. Os diagramas de impedância podem ser interpretados de acordo com o modelo de circuitos elétricos representando associações de elementos de circuito $R C$ (Resistência-Capacitância) submetidos a uma diferença de potencial senoidal. Assim, a resposta elétrica pode ser modelada a partir de um circuito elétrico equivalente ou associação de circuitos.

A Figura 43 mostra os diagramas de impedância de amostras sinterizadas pelo método convencional a $1200{ }^{\circ} \mathrm{C}$ em vários tempos de patamar obtidos a $380{ }^{\circ} \mathrm{C}$. Os números nos diagramas representam o logaritmo decimal da frequência. Os diagramas apresentaram dois semicírculos, o primeiro posicionado na região de alta frequência, representa a contribuição do grão e o segundo semicírculo, a baixas frequências, representa a contribuição do contorno de grão para a resposta elétrica. Esses diagramas foram modelados por dois circuitos elétricos $R C$ associados em série. Observa-se que a fase romboédrica diminui a condutividade elétrica do grão do material. O mesmo comportamento foi observado para a fase tetragonal $t^{\prime}$ no ScCeSZ ${ }^{(29)}$.

A menor condutividade do contorno de grão encontrada para a amostra sinterizada por $0,5 \mathrm{~h}$ pode ser explicada com base no pequeno tamanho médio de grãos e maior porosidade residual em relação às outras amostras, além da menor condutividade da fase romboédrica. $\mathrm{O}$ aumento do tempo de patamar promoveu 0 aumento da condutividade nos contornos de grão. Esse comportamento é esperado, pois a diminuição na área ocupada pelos contornos de grão devido ao aumento de tamanho dos grãos promove a diminuição da resistência elétrica intergranular e, portanto, aumento da condutividade. 
Isto acontece, pois os contornos de grão oferecem resistência à migração dos portadores de carga iônicos, ou seja, atuam como uma barreira adicional para a difusão. No entanto, nenhuma influência do tamanho dos grãos na resposta elétrica foi observada nas amostras sinterizadas a $1200{ }^{\circ} \mathrm{C}$ por 5 e $15 \mathrm{~h}$. Estas amostras possuem $G(0,7$ e 1,42 $\mu \mathrm{m}$, respectivamente) diferentes, porém as densidades são similares (>99,6\%).

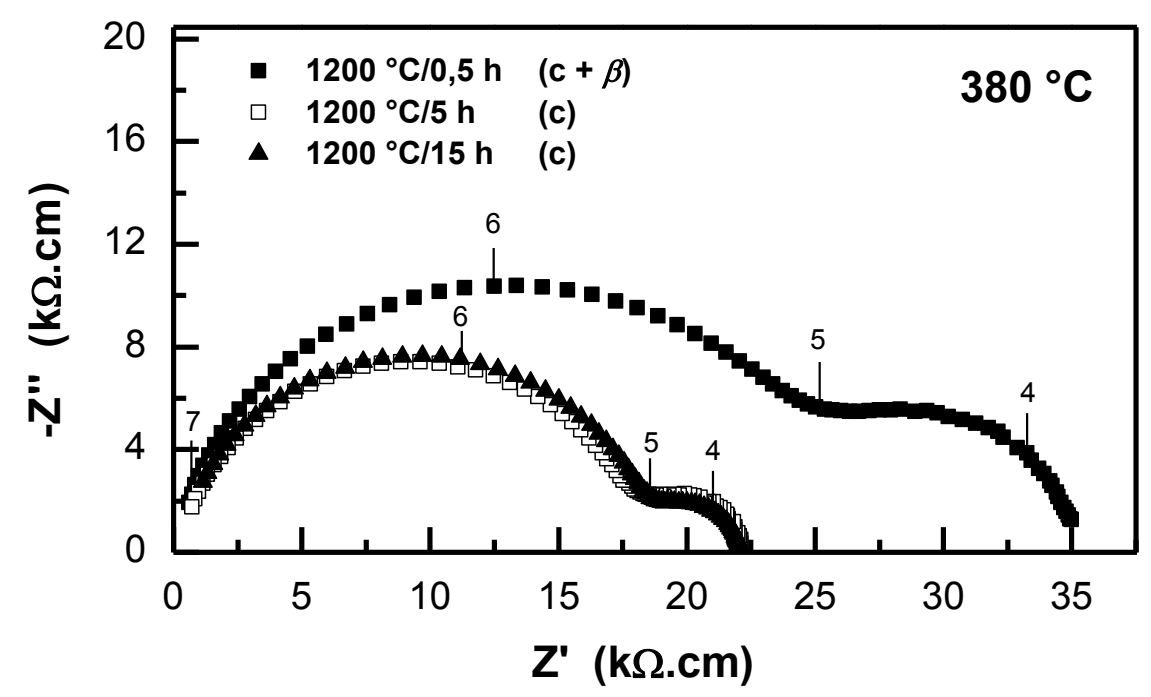

Figura 43. Diagramas de impedância de amostras sinterizadas a $1200^{\circ} \mathrm{C}$ por 0,5 , 5 e $15 \mathrm{~h}$ obtidos a $380^{\circ} \mathrm{C}$. Os números $4,5,6$ e 7 correspondem ao $\log _{10}$ (frequência) para o correspondente ponto.

A Figura 44 mostra os diagramas de impedância das amostras sinterizadas pelos diferentes métodos obtidos a $380^{\circ} \mathrm{C}$. O comportamento elétrico observado para amostras cúbicas monofásicas sinterizadas pelos métodos convencional e de duas etapas apresentou-se similar. Por outro lado, as condutividades elétricas intragranulares das amostras sinterizadas por SPS e da amostra sinterizada a $1200^{\circ} \mathrm{C}$ por $0,5 \mathrm{~h}$ são inferiores às das amostras monofásicas. Da mesma forma que foi necessário aumentar o tempo ou a temperatura de sinterização para favorecer a predominância da fase cúbica em relação à fase $\beta$ em amostras sinterizadas pelo método convencional, o aumento da temperatura e do tempo de patamar em amostras sinterizadas por SPS também foi necessário para favorecer a fase cúbica em relação à tetragonal, o que está de acordo com os resultados de Raman (Figura 40). 


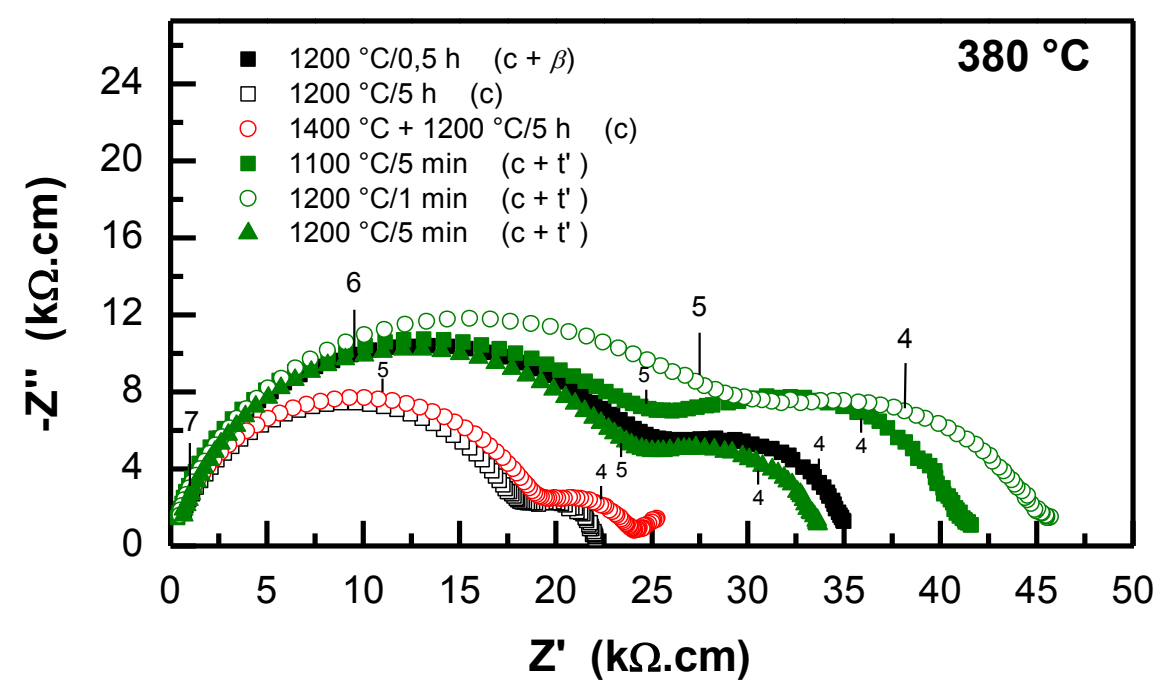

Figura 44. Diagramas de impedância de amostras sinterizadas pelos métodos convencional, de duas etapas e SPS obtidos a $380^{\circ} \mathrm{C}$. Os números $4,5,6$ e 7 correspondem ao $\log _{10}$ (frequência) para 0 correspondente ponto.

A condutividade elétrica das amostras foi determinada a partir dos valores de resistência obtidos pela deconvolução dos semicírculos nos diagramas de impedância. A Figura 45 mostra o gráfico de Arrhenius da condutividade elétrica do grão para diversas amostras sinterizadas pelos métodos convencional, de duas etapas e SPS. Observa-se que todas as amostras apresentaram o mesmo comportamento: uma única inclinação no intervalo de temperatura de 300 a $450{ }^{\circ} \mathrm{C}$. No entanto, em relação aos métodos convencional e de duas etapas, as amostras sinterizadas a $1200{ }^{\circ} \mathrm{C}$ por $0,5 \mathrm{~h}$ e $1300{ }^{\circ} \mathrm{C}$ por $0 \mathrm{~h}$ apresentaram condutividade ligeiramente inferior. Esse comportamento é atribuído à fase secundária romboédrica, a qual foi evidenciada pelos difratogramas de raios X nas Figuras 27 e 24, respectivamente. As condições de sinterização assistida por campo elétrico promoveram condutividades próximas as das amostras que apresentaram fase romboédrica. A inclinação é um pouco diferente das amostras com fase única cúbica. 


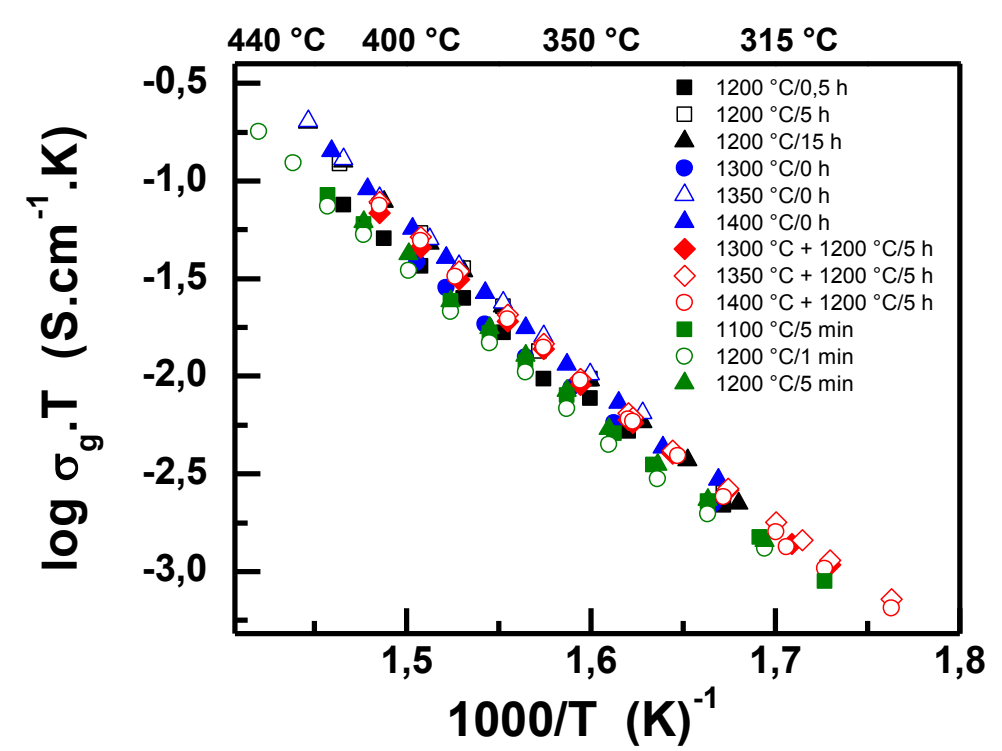

Figura 45. Gráficos de Arrhenius para a condutividade elétrica do grão de amostras de ScCeSZ sinterizadas, em diferentes condições, pelos métodos convencional, de duas etapas e SPS.

A Figura 46 mostra o gráfico de Arrhenius da condutividade elétrica do contorno de grão para diversas amostras sinterizadas pelos três métodos. Pode-se observar que, de modo geral, o aumento da temperatura e do tempo de patamar promoveu o aumento da condutividade intergranular. No entanto, a influência do tamanho dos grãos na condutividade elétrica é mais significativa em amostras com tamanho médio de grãos inferiores a aproximadamente $0,7 \mu \mathrm{m}$.

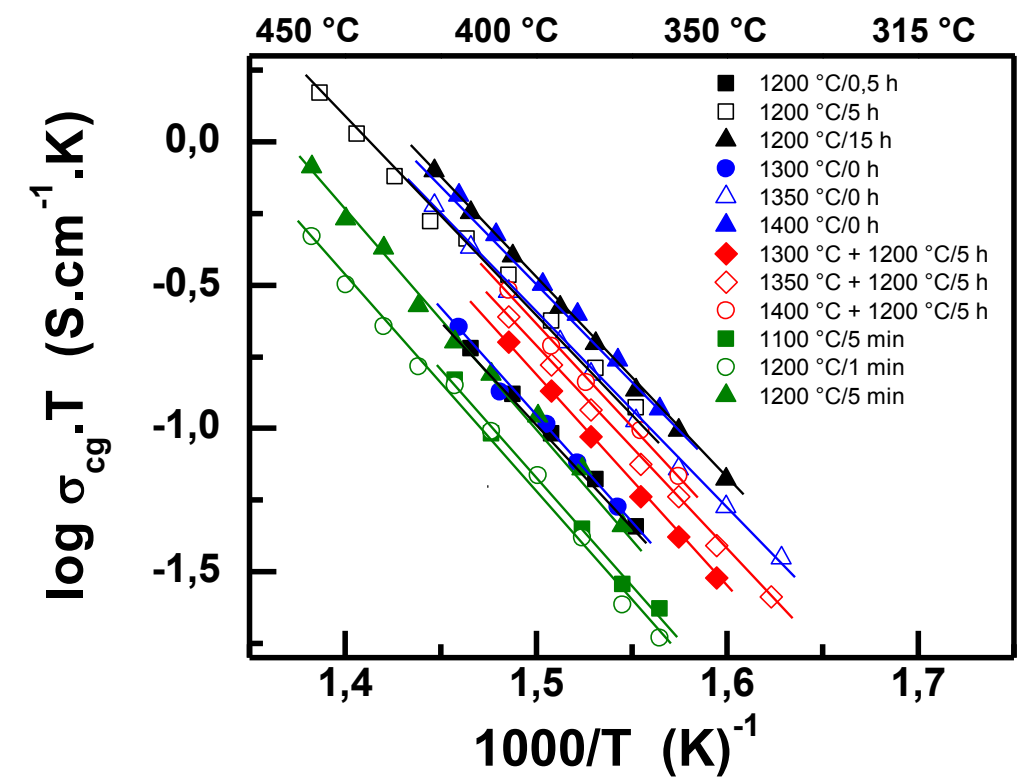

Figura 46. Gráficos de Arrhenius para condutividade elétrica do contorno de grão de amostras de ScCeSZ sinterizadas, em diferentes condições, pelos métodos convencional, de duas etapas e SPS. 
Para investigação do efeito resultante do tamanho dos grãos na condutividade intergranular, os gráficos de Arrhenius da condutividade elétrica do contorno de grão foram normalizados pelo tamanho médio de grãos. A Figura 47 mostra os gráficos de Arrhenius normalizados para diversas amostras. Nenhuma mudança significativa na condutividade dos contornos de grão ocorreu após correção pelo tamanho médio de grãos. Portanto, a mudança observada na condutividade elétrica intergranular na Figura 46 está associada somente à diminuição da área de bloqueio dos contornos de grãos. As ligeiras variações observadas nos gráficos de Arrhenius normalizados são atribuídas às incertezas associadas aos valores de condutividade obtidos pelas modelagens dos diagramas de impedância.

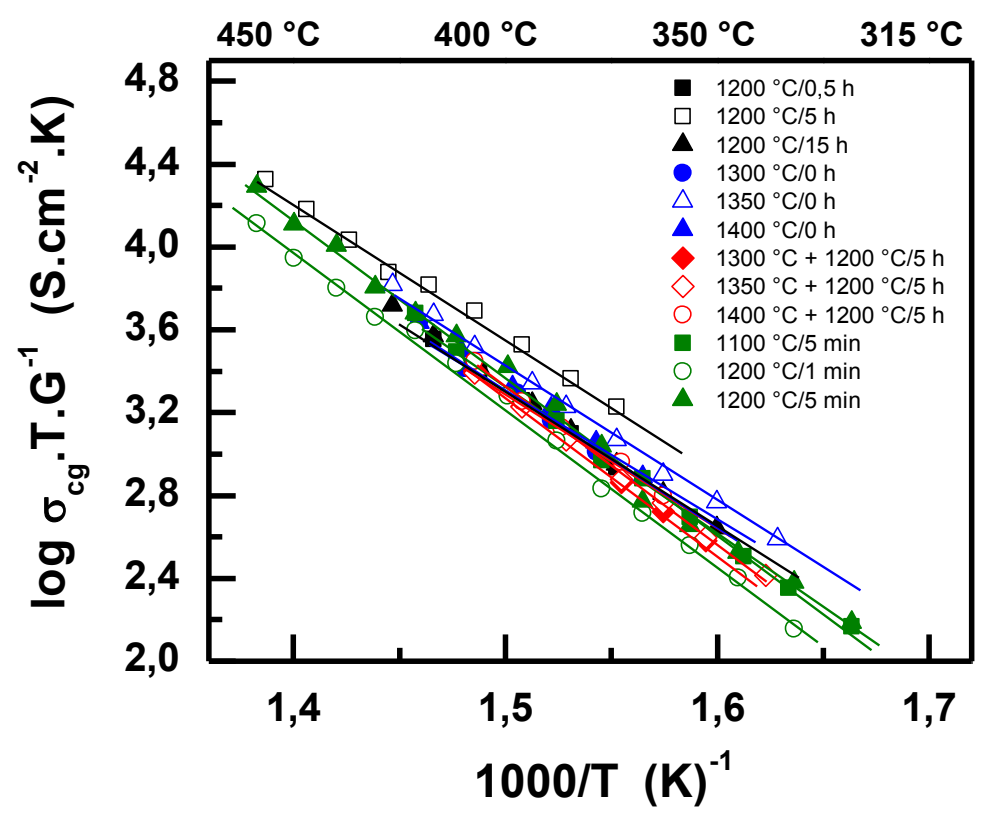

Figura 47. Gráficos de Arrhenius para condutividade do contorno de grão corrigida pelo tamanho médio de grãos de amostras de ScCeSZ sinterizadas, em diferentes condições, pelos métodos convencional, de duas etapas e SPS.

Conforme discutido anteriormente, a condutividade intergranular pode ser influenciada pelo tamanho dos grãos, porosidade residual e fase secundária. Dessa forma, com base nos resultados apresentados (Figura 47), torna-se evidente que o menor tamanho de grãos é o efeito predominante. 
A Figura 48 mostra os gráficos de Arrhenius para a condutividade elétrica total de amostras do presente trabalho $\left(^{*}\right)$ e dos principais estudos encontrados na literatura. As referências para cada material estão indicadas na legenda. A condutividade elétrica total é a soma das contribuições do grão e contorno de grão para a resposta elétrica. De modo geral, os gráficos de Arrhenius para a condutividade elétrica do ScCeSZ produzido pela Fuel Cell Materials sinterizado pelos métodos convencional e de duas etapas apresentaram bom acordo com as condutividades da zircônia-escândia-céria dos trabalhos reportados na literatura. Em relação à zircônia contendo $11 \%$ em mol de escândia, a condutividade apresentou-se superior na faixa de temperatura investigada.

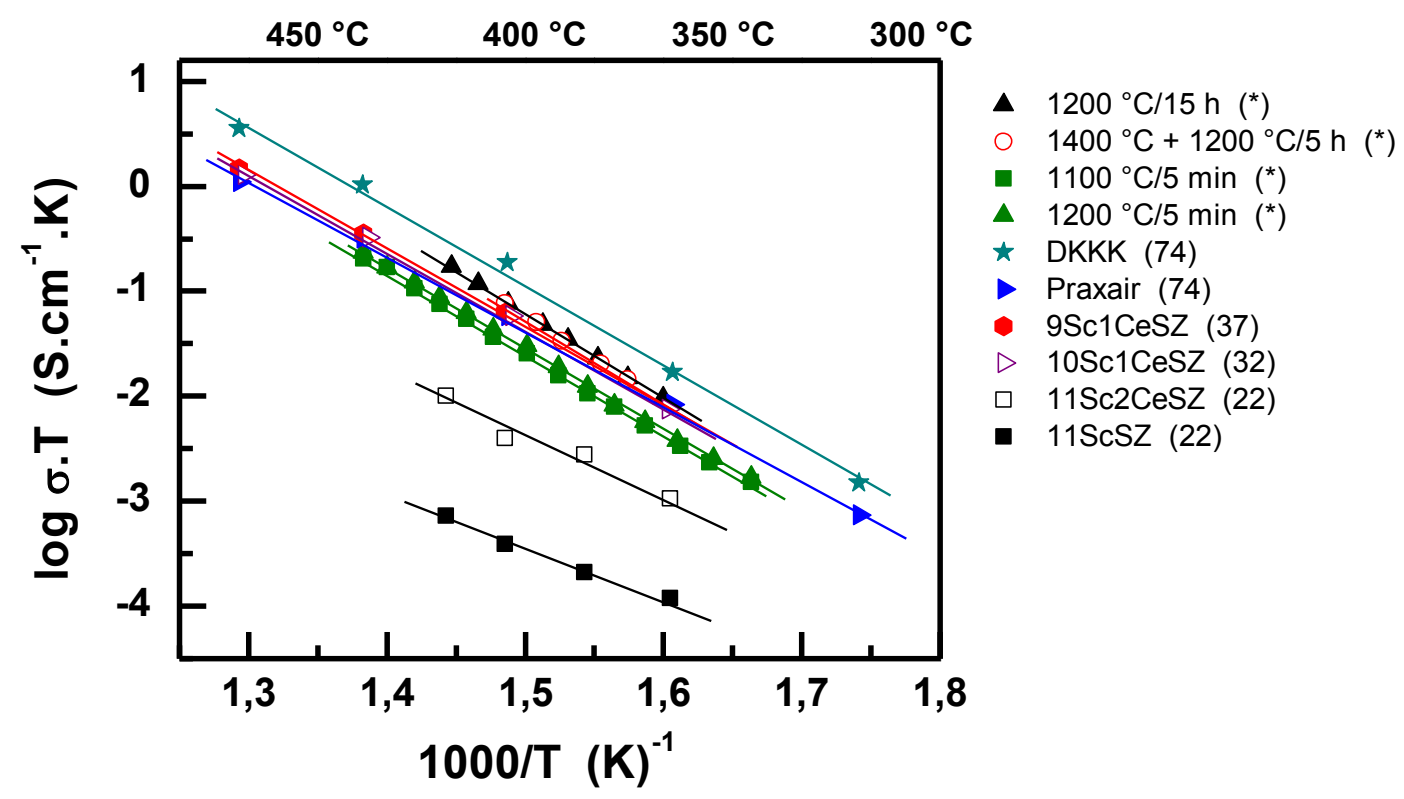

Figura 48. Gráficos de Arrhenius da condutividade elétrica total do $11 \mathrm{ScSZ}$ e do ScCeSZ de diversas referências e sinterizado em diferentes condições no presente trabalho $\left(^{*}\right)$.

Os valores de condutividade elétrica encontrados a $450{ }^{\circ} \mathrm{C}$ de amostras sinterizadas em diferentes condições no presente trabalho $\left({ }^{*}\right)$ e de alguns estudos encontrados na literatura estão listados na Tabela V. De modo geral, as amostras deste trabalho apresentaram condutividades a $450^{\circ} \mathrm{C}$ semelhantes em relação ao ScCeSZ estudado por diferentes métodos. Os resultados obtidos também são compatíveis com outros trabalhos da literatura ${ }^{(29,36)}$. Apenas o material da empresa DKKK sinterizado a $1500{ }^{\circ} \mathrm{C}$ apresentou condutividade superior (74). A condutividade elétrica relativamente baixa da zircônia-escândia-céria da Praxair foi atribuída à presença de Si segregado nos contornos de grão ${ }^{(74)}$. 
Tabela V. Condutividade elétrica total encontrada a $450{ }^{\circ} \mathrm{C}$ para amostras de ScCeSZ sinterizadas em diferentes condições no presente trabalho $\left(^{*}\right)$ e de amostras de $10 \mathrm{Sc} 1 \mathrm{CeSZ}$, 5Sc6CeSZ e $8 \mathrm{ScSZ}$ de trabalhos reportados na literatura.

\begin{tabular}{|c|c|c|c|c|}
\hline Material & $\begin{array}{c}\text { Fabricante ou } \\
\text { Processo de Síntese }\end{array}$ & $\begin{array}{l}\text { Condições de } \\
\text { Sinterização }\end{array}$ & $\begin{array}{l}\text { Condutividade Total } \\
\text { a } 450^{\circ} \mathrm{C}\left(10^{-4} \mathrm{~S}^{-\mathrm{cm}^{-1}}\right)\end{array}$ & Referência \\
\hline ScCeSZ & $\mathrm{FCM}$ & $1200^{\circ} \mathrm{C} / 15 \mathrm{~h}$ & 7,8 & * \\
\hline ScCeSZ & FCM & $1400^{\circ} \mathrm{C}+1200^{\circ} \mathrm{C} / 5 \mathrm{~h}$ & 7,2 & * \\
\hline ScCeSZ & FCM & $1100^{\circ} \mathrm{C} / 5 \mathrm{~min}$ & 2,8 & * \\
\hline ScCeSZ & FCM & $1200^{\circ} \mathrm{C} / 5 \mathrm{~min}$ & 3,2 & * \\
\hline $10 \mathrm{Sc} 1 \mathrm{CeSZ}$ & DKKK & $1500^{\circ} \mathrm{C}$ & 14 & (74) \\
\hline $10 \mathrm{Sc} 1 \mathrm{CeSZ}$ & DKKK & $1400^{\circ} \mathrm{C}$ & 6,3 & (39) \\
\hline $10 \mathrm{Sc} 1 \mathrm{CeSZ}$ & Praxair & $1500^{\circ} \mathrm{C}$ & 4,5 & (74) \\
\hline $10 \mathrm{Sc} 1 \mathrm{CeSZ}$ & Coprecipitação & $1580^{\circ} \mathrm{C} / 10 \mathrm{~h}$ & 0,25 & (27) \\
\hline $10 \mathrm{Sc} 1 \mathrm{CeSZ}$ & Mistura de Óxidos & $1550^{\circ} \mathrm{C} / 6 \mathrm{~h}$ & 4,5 & (32) \\
\hline $5 \mathrm{Sc} 6 \mathrm{CeSz}$ & Coprecipitação & $1580^{\circ} \mathrm{C} / 10 \mathrm{~h}$ & 4,0 & (27) \\
\hline 8ScSZ & Pechini & $1000^{\circ} \mathrm{C} / 24 \mathrm{~h}$ & 8,9 & (17) \\
\hline
\end{tabular}

Os valores das energias de ativação para o processo de condução dos grãos $\left(E_{a g}\right)$ e contornos de grão $\left(E_{a c g}\right)$ obtidos pelos diagramas de Arrhenius na faixa de temperatura de 300 a $450^{\circ} \mathrm{C}$ (Figuras 45 e 46) são listados na Tabela VI para as diferentes condições de sinterização. As energias de ativação do grão encontradas para amostras sinterizadas pelo método convencional que apresentaram alguma quantidade de fase romboédrica $\left(1200{ }^{\circ} \mathrm{C}\right.$ por $0,5 \mathrm{~h} \mathrm{e}$ $1300{ }^{\circ} \mathrm{C}$ por $0 \mathrm{~h}$ ) foram ligeiramente inferiores em relação às amostras monofásicas e compatível com o valor encontrado para as amostras sinterizadas por SPS. Os valores apresentados na Tabela VI são próximos das energias de ativação encontradas na faixa de temperatura de 300 a $500{ }^{\circ} \mathrm{C}$ para $\mathrm{O}$ ScCeSZ ${ }^{(38)}$, ScYSZ ${ }^{(23)}$ e ScAISZ ${ }^{(24)}$. 
Tabela VI. Valores de energia de ativação para o processo de condução dos grãos $E_{a g}$ e contornos de grão $E_{a c g}$ de amostras sinterizadas pelos métodos convencional, de duas etapas e SPS na faixa de temperatura de 300 a $450{ }^{\circ} \mathrm{C}$.

\begin{tabular}{ccc}
\hline Condições de Sinterização & $\boldsymbol{E}_{\text {ag }}(\mathrm{eV})$ & $\boldsymbol{E}_{\text {a cg }}(\mathrm{eV})$ \\
\hline $1200^{\circ} \mathrm{C} / 0,5 \mathrm{~h}$ & $1,49 \pm 0,03$ & $1,41 \pm 0,02$ \\
$1200^{\circ} \mathrm{C} / 5 \mathrm{~h}$ & $1,61 \pm 0,04$ & $1,29 \pm 0,03$ \\
$1200^{\circ} \mathrm{C} / 15 \mathrm{~h}$ & $1,63 \pm 0,02$ & $1,40 \pm 0,01$ \\
$1300^{\circ} \mathrm{C} / 0 \mathrm{~h}$ & $1,51 \pm 0,02$ & $1,44 \pm 0,09$ \\
$1350^{\circ} \mathrm{C} / 0 \mathrm{~h}$ & $1,62 \pm 0,03$ & $1,35 \pm 0,02$ \\
$1400^{\circ} \mathrm{C} / 0 \mathrm{~h}$ & $1,61 \pm 0,03$ & $1,39 \pm 0,03$ \\
$1300^{\circ} \mathrm{C}+1200^{\circ} \mathrm{C} / 5 \mathrm{~h}$ & $1,62 \pm 0,02$ & $1,76 \pm 0,03$ \\
$1350^{\circ} \mathrm{C}+1200^{\circ} \mathrm{C} / 5 \mathrm{~h}$ & $1,69 \pm 0,01$ & $1,40 \pm 0,03$ \\
$1400^{\circ} \mathrm{C}+1200^{\circ} \mathrm{C} / 5 \mathrm{~h}$ & $1,64 \pm 0,02$ & $1,76 \pm 0,06$ \\
$1100^{\circ} \mathrm{C} / 5 \mathrm{~min}$ & $1,47 \pm 0,02$ & $1,59 \pm 0,06$ \\
$1200^{\circ} \mathrm{C} / 1 \mathrm{~min}$ & $1,58 \pm 0,02$ & $1,42 \pm 0,09$ \\
$1200^{\circ} \mathrm{C} / 5 \mathrm{~min}$ & $1,54 \pm 0,01$ & $1,46 \pm 0,04$ \\
\hline \hline
\end{tabular}

A Figura 49 mostra os gráficos de Arrhenius para a condutividade elétrica total obtidos na faixa de temperatura de 300 a $800{ }^{\circ} \mathrm{C}$ para a amostra sinterizada a $1400{ }^{\circ} \mathrm{C}$ por tempo de patamar nulo e das amostras sinterizadas por SPS. Embora seja observada uma pequena diferença nos valores de condutividade abaixo de $400{ }^{\circ} \mathrm{C}$, acima desta temperatura, os valores de condutividade apresentaram-se muito semelhantes, com exceção da amostra sinterizada a $1200{ }^{\circ} \mathrm{C}$ por $5 \mathrm{~min}$, a qual provavelmente possui maior quantidade de cério reduzido devido à exposição por maior tempo em atmosfera redutora.

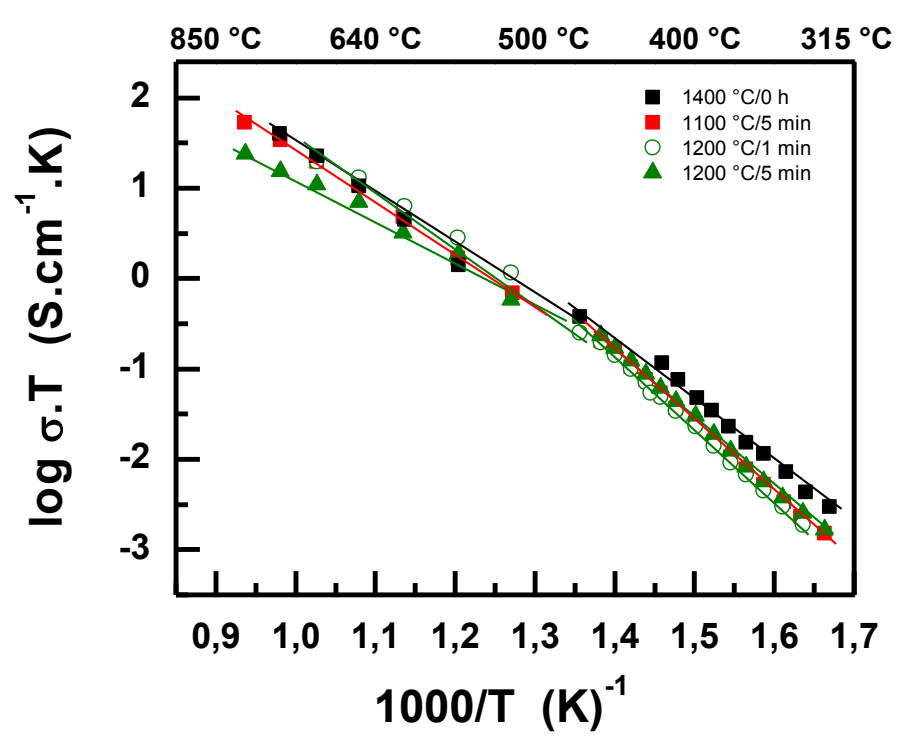

Figura 49. Gráficos de Arrhenius para a condutividade elétrica total de amostras de ScCeSZ sinterizadas a $1400^{\circ} \mathrm{C} / 0 \mathrm{~h}$ e por SPS. 
Os valores das energias de ativação para o processo de condução obtidos pelos diagramas de Arrhenius nas faixas de temperaturas de 300 a $450{ }^{\circ} \mathrm{C}$ e 450 a $800^{\circ} \mathrm{C}$ (Figuras 49) são listados na Tabela VII para as diferentes condições de sinterização. As energias de ativação da condutividade elétrica total estão de acordo com os valores reportados na literatura para o ScCeSz ${ }^{(38)}$.

Tabela VII. Valores de energia de ativação $\left(E_{a}\right)$ para o processo de condução das amostras sinterizadas a $1400^{\circ} \mathrm{C}$ por tempo de patamar nulo e por SPS.

\begin{tabular}{ccc}
\hline \hline \multirow{2}{*}{$\begin{array}{c}\text { Condições de } \\
\text { Sinterização }\end{array}$} & \multicolumn{2}{c}{$\boldsymbol{E}_{\mathbf{a}}(\mathrm{eV})$} \\
\cline { 2 - 3 } & $\mathbf{3 0 0 - \mathbf { 4 5 0 }}{ }^{\circ} \mathbf{C}$ & $\mathbf{4 5 0}-\mathbf{8 0 0}{ }^{\circ} \mathbf{C}$ \\
\hline $1400{ }^{\circ} \mathrm{C} / 0 \mathrm{~h}$ & $1,51 \pm 0,03$ & $1,16 \pm 0,08$ \\
$1100^{\circ} \mathrm{C} / 5 \mathrm{~min}$ & $1,54 \pm 0,01$ & $1,14 \pm 0,03$ \\
$1200^{\circ} \mathrm{C} / 1 \mathrm{~min}$ & $1,59 \pm 0,01$ & $1,22 \pm 0,06$ \\
$1200^{\circ} \mathrm{C} / 5 \mathrm{~min}$ & $1,55 \pm 0,01$ & $0,84 \pm 0,04$ \\
\hline \hline
\end{tabular}




\section{CONCLUSÕES}

A adição de céria à zircônia-escândia promove a estabilização da fase cúbica à temperatura ambiente e a estabilidade química e estrutural sob condições de ciclagem térmica até $1000{ }^{\circ} \mathrm{C}$. O ScCeSZ retrai $21 \%$ até $1380^{\circ} \mathrm{C}$ com retração máxima a $1180^{\circ} \mathrm{C}$.

Após sinterização por método convencional, em tempo de patamar nulo, o material tornou-se completamente denso (densidade relativa maior que 99\%) a partir de $1350{ }^{\circ} \mathrm{C}$. Entre as temperaturas de 1150 e $1300^{\circ} \mathrm{C}$ foi detectada a fase romboédrica na matriz cúbica, enquanto que, em temperaturas inferiores e superiores há predominância da fase cúbica.

Em temperaturas inferiores a $1150{ }^{\circ} \mathrm{C}$ é necessário tempo de patamar muito extenso (cerca de $10 \mathrm{~h}$ ) para que a cerâmica consiga atingir uma densidade relativa próxima de $90 \%$. Entretanto, para temperaturas acima de $1150{ }^{\circ} \mathrm{C}$, a densificação de $90 \%$ para o ScCeSZ ocorre em curto período de tempo (alguns minutos). Para temperaturas mais elevadas $\left(1500{ }^{\circ} \mathrm{C}\right.$ ) a sinterização convencional promoveu a mudança parcial da estrutura cristalina de cúbica para romboédrica (overfiring).

Os resultados de difração de raios $X$ mostraram que é necessária uma seleção cuidadosa das condições de sinterização para obtenção do material cúbico monofásico.

Nas amostras sinterizadas em duas etapas, ao utilizar $T_{1}$ igual a $1200{ }^{\circ} \mathrm{C}$ (para uma densidade relativa igual a $75 \%$ ) houve formação de fase romboédrica. O método de sinterização em duas etapas mostrou-se eficaz em relação à supressão ao menos parcial do crescimento de grãos. Neste método de sinterização $T_{1}$ é determinante para a obtenção de um material monofásico. O material cúbico foi obtido apenas para $\mathrm{T}_{1}$ superior a $1300^{\circ} \mathrm{C}$.

A sinterização assistida por campo elétrico permitiu diminuir a temperatura necessária para se obter uma elevada densificação (> 95\%), em tempo de patamar curto ( $\leq 5 \mathrm{~min}$ ), e promoveu uma diminuição do tamanho médio de grãos em comparação com o processo convencional de sinterização. 
Nas amostras sinterizadas por SPS houve formação de fase tetragonal. O tratamento térmico a $900{ }^{\circ} \mathrm{C}$ por $4 \mathrm{~h}$, necessário para eliminar carbono e reoxidar o $\mathrm{Ce}^{3+}$ para $\mathrm{Ce}^{4+}$ promoveu a formação da fase romboédrica.

As amostras que apresentaram as fases secundárias romboédrica e tetragonal apresentaram condutividade elétrica intragranular inferior às amostras cúbicas monofásicas. Por outro lado, a menor condutividade intergranular foi atribuída ao menor tamanho médio de grãos, ou seja, o bloqueio aos portadores de carga nos contornos de grão é essencialmente dependente da densidade (número de contornos de grão/área) de contornos de grão.

Os valores de condutividade elétrica de amostras cúbicas monofásicas de ScCeSZ estão de acordo com os valores reportados na literatura. 


\section{REFERÊNCIAS}

(1) SUBBARAO, E.C. Solid electrolytes and their applications. Nova Yorque: Plenun Press, 1980.

(2) GOODENOUGH, J.B. Ceramic solid electrolytes. Solid State lonics, v. 94, p.17-25, 1997.

(3) MUCCILLO, E.N.S. Condutores de íons oxigênio: uma breve revisão. Cerâmica, v.54, p. 129-144, 2008.

(4) SOMIYA S.; YAMAMOTO, N.; YANAGIDA, H. Science and technology of zirconia III, in Advances in Ceramics, v. 24B. American Ceramic Society, 1988.

(5) SAMMES, N.M. Fuel cell technology: reaching toward commercialization. Londres: Spring, 2006.

(6) MIZUTANI, Y.; TAMURA, M.; KAWAI, M.; YAMAMOTO, O. Development of high-performance electrolyte in SOFC. Solid State lonics, v. 72, p. 271-275, 1994.

(7) YAMAMOTO, O.; ARATI, Y.; TAKEDA, Y.; IMANISHI, N.; MIZUTANI, Y.; KAWAI, M.; NAKAMURA, Y. Electrical conductivity of stabilized zirconia with ytterbia and scandia. Solid State Ionics, v. 79, p. 137142, 1995.

(8) ARACHI, Y.; SAKAI, H.; YAMAMOTO, O.; TAKEDA, Y.; IMANISHAI, N. Electrical conductivity of the $\mathrm{ZrO}_{2}-\mathrm{Ln}_{2} \mathrm{O}_{3}$ ( $\mathrm{Ln}=$ lanthanides) system. Solid State lonics, v. 121, p. 133-139, 1999.

(9) BADWAL, S.P.S.; CIACCHI, F.T.; MILOSEVIC, D. Scandia-zirconia electrolytes for intermediate temperature solid oxide fuel cell operation. Solid State Ionics, v. 136/137, p. 91-99, 2000.

(10) FUJIMORI, H.; YASHIMA, M.; KAKIHANA, M.; YOSHIMURA, M. Structural changes of scandia-doped zirconia solid solutions: Rietveld analysis and Raman scattering. Journal of the American Ceramic Society, v. 81, n. 11, p. 2885-2893, 1998. 
(11) RUH, R.; GARRET, H.J.; DOMAGALA, R.F.; PATEL, V.A. The system zirconia-scandia. Journal of the American Ceramic Society, v. 60, p. 399-403, 1977.

(12) LEONI, M.; JONES, R.L.; SCARDEI, P. Phase stability of scandiayttria-stabilized zirconia TBCs. Surface and Coatings Technology, v. 108-109, p. 107-113, 1998.

(13) ABDALA, P.M.; CRAIEVICH, A.F.; FANTINI, M.C.A.; TEMPERINI, M.L.A.; LAMAS, D.G. Metastable phase diagram of nanocrystalline $\mathrm{ZrO}_{2}-\mathrm{Sc}_{2} \mathrm{O}_{3}$ solid solutions. Journal of Physical Chemical C, v. 113, p. 18661-18666, 2009.

(14) ABDALA, P.M.; LAMAS, D.G.; FANTINI, M.C.A.; CRAIEVICH, A.F. Retention at room temperature of the tetragonal t"-form in $\mathrm{Sc}_{2} \mathrm{O}_{3}$-doped $\mathrm{ZrO}_{2}$ nanopowders. Journal of Alloys and Compounds, v. 495, p. 561-564, 2010.

(15) NOMURA, K.; MIZUTANI, Y.; KAWAI, M.; NAKAMURA, Y.; YAMAMOTO, O. Aging and Raman scattering study of scandia and yttria doped zirconia. Solid State Ionics, v. 132, p. 235-239, 2000.

(16) BADWAL, S.P.S.; CIACCHI, F.T.; RAJENDRAN, S.; DRENNAN, J. An investigation of conductivity, microstructure and stability of electrolyte compositions in the system 9 mol\% $\left(\mathrm{Sc}_{2} \mathrm{O}_{3}-\mathrm{Y}_{2} \mathrm{O}_{3}\right)-$ $\mathrm{ZrO}_{2}\left(\mathrm{Al}_{2} \mathrm{O}_{3}\right)$. Solid State Ionics, v. 109, p. 167-186, 1998.

(17) HUANG, H.; HSIEH, C.H.; KIM, N.; STEBBINS, J.; PRINZ, F. Structure, local environment, and ionic conduction in scandia stabilized zirconia, Solid State Ionics, v. 179, p. 1442-1445, 2008.

(18) OKAMOTO, M.; AKIMUNE, Y.; FURUYA, K.; HATANO, M.; YAMANAKA, M.; UCHIYAMA, M. Phase transition and electrical conductivity of scandia-stabilized zirconia prepared by spark plasma sintering process. Solid State Ionics, v. 176, p. 675-680, 2005.

(19) TAMBURINI, U.A.; GARAY, J.E.; MUNIR, Z.A. Fast low-temperature consolidation of bulk nanometric ceramic materials. Scripta Materialia, v. 54 , p. $823-828,2006$. 
(20) TROMBINI, V.; PALLONE, E.M.J.A.; MUNIR, Z.A.; TOMASI, R. Spark plasma sintering (SPS) de nanocompósitos de $\mathrm{Al}_{2} \mathrm{O}_{3}-\mathrm{ZrO}_{2}$. Cerâmica, v. 53, p. 62-67, 2007.

(21) LEI, Z.; ZHU, Q. Low temperature processing of dense nanocrystalline scandia-doped zirconia (ScSZ) ceramics. Solid State Ionics, v. 176, p. 2791-2797, 2005.

(22) ARACHI, Y.; ASAI, T.; YAMAMOTO, O.; TAKEDA, Y.; IMANISHI, N.; KAWATE, K.; TAMAKOSHI, C. Electrical conductivity of $\mathrm{ZrO}_{2}-\mathrm{Sc}_{2} \mathrm{O}_{3}$ doped with $\mathrm{HfO}_{2}, \mathrm{CeO}_{2}$, and $\mathrm{Ga}_{2} \mathrm{O}_{3}$. Journal of the Electrochemical Society, v. 148, n. 5, p. A520-A523, 2001.

(23) POLITOVA, T.I.; IRVINE, J.T.S. Investigation of scandia-yttria-zirconia system as an electrolyte material for intermediate temperature fuel cells-influence of yttria content in system $\left(\mathrm{Y}_{2} \mathrm{O}_{3}\right)_{\times}\left(\mathrm{Sc}_{2} \mathrm{O}_{3}\right)_{(11-x)}(\mathrm{ZrO} 2)_{89}$. Solide State lonics, v. 168, p. 153-165, 2004.

(24) TIETZ, F.; FISCHER, W.; HAUBERH, T.; MARIOTTO, G. Structural evolution of Sc-containing zirconia electrolytes. Solid State Ionics, v. 100, p. 289-295, 1997.

(25) LEI, Z.; ZHU, Q. Phase transformation and low temperature sintering of manganese oxide and scandia co-doped zirconia. Materials Letters, v. 61, n. 6 , p. 1311-1314, 2007.

(26) FERGUS, J.W. Electrolytes for solid oxide fuel cells. Journal of Powder Sources, v. 162, p. 30-40, 2006.

(27) LIU, M.; HE, C.; WANG, J.; WANG, W.G.; WANG, Z. Investigation of $\left(\mathrm{CeO}_{2}\right)_{x}\left(\mathrm{Sc}_{2} \mathrm{O}_{3}\right)_{(0.11-x)}\left(\mathrm{ZrO}_{2}\right)_{0.89}(x=0.01-0.10)$ electrolyte materials for intermediate-temperature solid oxide fuel cell. Journal of Alloys and Compounds, v. 502, n. 1, p. 319-323, 2010.

(28) YAMAJI, K.; KISHIMOTO, H.; XIONG, Y.P.; HORITA, T.; SAKAI, N.; YOKOKAWA, $\mathrm{H}$. Fabrication of anode supported electrolyte with CeScSZ electrolyte and NiO-CeScSZ anode by EPD techniques. Solid Oxide Fuel Cell VIII, The Electrochemical Society Proceedings, PV2003-07, p.1011-1018, 2003/04. 
(29) WANG, Z.; CHENG, M.; BI, Z.; DONG, Y.; ZHANG, H.; ZHANG, J.; FENG, Z.; LI, C. Structure and impedance of $\mathrm{ZrO}_{2}$ doped with $\mathrm{Sc}_{2} \mathrm{O}_{3}$ and $\mathrm{CeO}_{2}$. Materials Letters, v. 59, n. 19/20, p. 2579-2582, 2005.

(30) LEE, D.S.; KIM, W.S.; CHOI, S.H.; KIM, J.; LEE, H.W.; LEE, J.H. Characterization of $\mathrm{ZrO}_{2}$ co-doped with $\mathrm{Sc}_{2} \mathrm{O}_{3}$ and $\mathrm{CeO}_{2}$ electrolyte for the application of intermediate temperature SOFCs. Solid State lonics, v. 176, p. 33-39, 2005.

(31) OMAR, S.; BONANOS, N. lonic conductivity ageing behaviour of 10 mol.\% $\mathrm{Sc}_{2} \mathrm{O}_{3}-1$ mol.\% $\mathrm{CeO}_{2}-\mathrm{ZrO}_{2}$ ceramics. Journal of Materials Science, v. 45, p. 6406-6410, 2010.

(32) OMAR, S.; NAJIB, W.B.; BONANOS, N. Conductivity ageing studies on $1 \mathrm{M} 10 \mathrm{ScSZ}\left(\mathrm{M}^{4+}=\mathrm{Ce}, \mathrm{Hf}\right)$. Solid State lonics, v. 189, p. 100-106, 2011.

(33) PREIS, W.; EGGER. A.; WALDHÄUSL, J.; SITTE, W.; CARVALHO, E.; IRVINE, J.T.S. Bulk and grain boundary conductivities as function of temperature and oxygen partial pressure of scandia-stabilized zirconia co-doped with yttria and ceria. Electrochemical Society Transactions, v. 25, n. 2, p. 1635-1642, 2009.

(34) YARMOLENKO S.; SANKAR, J.; BERNIER, N.; KLIMOV, M.; KAPAT, J.; ORLOVSKAYA, N. Phase stability and sintering behavior of $10 \mathrm{~mol} \% \mathrm{Sc}_{2} \mathrm{O}_{3}-1 \mathrm{~mol} \% \mathrm{CeO}_{2}-\mathrm{ZrO}_{2}$ ceramics. Journal of Fuel Cell Science and Technology, v.6, p. 021007-8, 2009.

(35) DU, K.; KIM, C.H.; HEUER, A.H.; GOETTLER, R.; LIU, Z. Structural evolution and electrical properties of $\mathrm{Sc}_{2} \mathrm{O}_{3}$-stabilized $\mathrm{ZrO}_{2}$, aged at $850{ }^{\circ} \mathrm{C}$ in air and wet-forming gas ambient. Journal of the American Ceramic Society, v. 91, n. 5, p. 1626-1633, 2008.

(36) HELL, A.; VITAL, A.; HOLTAPPELS, P.; GRAULE, T. Flame spray synthesis and characterisation of stabilised $\mathrm{ZrO}_{2}$ and $\mathrm{CeO}_{2}$ electrolyte nanopowders for SOFC applications at intermediate temperatures. Journal of Electroceramics, v. 22, p. 40-46, 2009.

(37) ABBAS, H.A.; ARGIRUSIS, C.; KILO, M.; WIEMHÖFER, H.D.; HAMMAD, F.F.; HANAFI, Z.M. Preparation and conductivity of ternary scandia-stabilised zirconia. Solid State lonics, v. 184, p. 6-9, 2011. 
(38) LAGUNA-BERCERO, M.A.; SKINNER, S.J.; KILMER, J.A. Performance of solid oxide electrolysis cells based on scandia stabilized zirconia. Journal of Power Sources, v. 192, p. 126-131, 2009.

(39) MORI, M.; LIU, Y.; MA, S.; HASHIMOTO, S.; TAKEI, K. Investigation of Li dopant as a sintering aid for ScSZ electrolyte for IT-SOFC. Journal of the Korean Ceramic Society, v. 45, n. 12, p. 760-765, 2008.

(40) KINGERY, W.D. Introduction to ceramics. 2. ed. New York: John Wiley, 1960.

(41) KELLET, B.J.; LANGE, F.F. Thermodynamics of densification: I, sintering of simple particle arrays, equilibrium configurations, pore stability, and shrinkage. Journal of the American Ceramic Society, v. 72, n. 5, p. 725-734, 1989.

(42) WALAI, F. Modeling and simulation of elementary processes in ideal sintering. Journal of the American Ceramic Society, v. 89, n. 5, p. 1471-1484, 2006.

(43) CHEN, I.W.; WANG, X.W. Sintering dense nanocrystalline ceramics without final-stage grain growth. Nature, v. 404, p. 168-171, 2000.

(44) LEE, Y.I.; KIM, Y.W.; MITOMO, M.; KIM, D.Y. Fabrication of dense nanostructured silicon carbide ceramics through two-step sintering. Journal of the American Ceramic Society, v. 86, n. 10, p. 18031805, 2003.

(45) KIM, H.T.; HAN, Y.H. Sintering of nanocrystalline $\mathrm{BaTiO}_{3}$. Ceramics International, v. 30, p. 1719-1723, 2004.

(46) KIM, H.D.; PARK, Y.J.; HAN, B.D.; PARK, M.Q.; BAE, W.T.; KIM, Y.W.; LIN, H.T.; BECHER, P.F. Fabrication of dense bulk nano- $\mathrm{Si}_{3} \mathrm{~N}_{4}$ ceramics without secondary crystalline phase. Scripta Materialia, v. 54, p. 615-619, 2006.

(47) BODISOVÁ, K.; SAJGALIK, P.; GALUSEK, D.; SVANCAREK, P. Two-stage sintering of alumina with submicrometer grain size. Journal of the American Ceramic Society, v. 90, n. 1, p. 330-332, 2007. 
(48) MAZAHERI, M.; ZAHEDI, A.M.; SADRNEZHAADT, S.K. Two-step sintering of nanocrystalline $\mathrm{ZnO}$ compacts: effect of temperature on densification and grain growth. Journal of the American Ceramic Society, v. 91, n. 1, p. 56-63, 2008.

(49) BINNER, J.; ANNAPOORANI, K.; PAUL, A.; SANTACRUZ, I.; VAIDHYANATHAN, B. Dense nanostructured zirconia by two stage conventional/hybrid microwave sintering. Journal of the European Ceramic Society, v. 28, p. 973-977, 2008.

(50) BISWAS, K. Impedance spectroscopic behaviour of spark plasma sintered nanocrystalline scandia stabilized zirconia (SSZ). Ceramics International, v. 35, p. 2047-2051, 2009.

(51) SHIMONOSONO, T.; KIMURA, H.; SAKKA, Y. Effect of grain size on electrical properties of scandia-stabilized zirconia. Journal of the Ceramic Society of Japan, v. 118, n. 11, p. 1038-1043, 2010.

(52) ZHU, B. Solid oxide fuel cell (SOFC) technical challenges and solutions from nano-aspects. International Journal of Energy Research, v. 33, p. 1126-1137, 2009.

(53) PERERA, D.S.; TOKITA, M.; MORICCA, S. Comparative study of fabrication of $\mathrm{Si}_{3} \mathrm{~N}_{4} / \mathrm{SiC}$ composites by spark plasma sintering and hot isostactic pressing. Journal of the Ceramic Society, v. 18, p. 410404, 1998.

(54) MUNIRW, Z.A.; QUACH, D.V. Electric current activation of sintering, a review of the pulsed electric current sintering process. Journal of the American Ceramic Society, v. 94, n. 1, p. 1-19, 2011.

(55) CARNEIRO, M.B; MACHADO, I.F.; RODRIGUES, D. Influência dos parâmetros de sinterização por SPS no WC-Co. In: 6o Congresso Brasileiro de Engenharia de Fabricação. Caxias do Sul-RS, 2011.

(56) MENEZES, R.R.; KIMINAMI, R.H.G.A. Microwave sintering of aluminazirconia nanocomposites. Journal of Materials Processing Technology, v. 203, p. 513-517, 2008. 
(57) MENDELSON, M.I. Average grain size in polycrystalline ceramics. Journal of The American Ceramic Society, v. 52, n. 8, p. 443-446, 1969.

(58) KLEITZ, M.; KENNEDY, J.H. Resolution of multicomponents impedance diagrams. In: Proceedings of the International Conference on Fast Ion Transport in Solids, Electrodes and Electrolytes, ed. Vashishta, P.; Mundy, J.N.; Shenoy. G.K. North-Holland, Amsterdam, p.185-188, 1979.

(59) KLUG, H.P.; ALEXANDER, L.E. X-ray diffraction procedures: for polycrystalline and amorphous materials. 2. ed. New York: Wiley Interscience, 1974.

(60) GIOLITO, I.; IONASHIRO, M. Nomenclatura em análise térmica, parte II. Cerâmica, v. 34, n. 225, p. 163-164, 1988.

(61) MACKENZIE, R.C. NOMENCLATURE IN THERMAL ANALYSIS, PART IV. THERMOCHIMICA ACTA, V. 28, N. 1, P. 1-6, 1979.

(62) IONASHIRO, M. Princípios básicos da termogravimetria e análise térmica diferencial/ calorimetria exploratória diferencial. Araraquara: Giz, 2004.

(63) PADILHA, A. F.; AMBROZIO, F. Técnicas de análise microestrutural. São Paulo: Hemus, 1985.

(64) GOLDSTEIN, J.I.; YAKOWITZ, H. Practical scanning electron microscopy: electron and ion microprobe analysis. Nova lorque: Plenum Press, 1975.

(65) SKOOG, D.A.; HOLLER, F.J.; NIEMAN, T.A. Princípios de análise instrumental. 5. ed. Tradução: Ignez Caracelli, et al. Porto Alegre: Bookman, 2008.

(66) SALA, O. Fundamentos da espectroscopia Raman e no infravermelho. 2. ed. São Paulo: Editora Unesp, 2008.

(67) MCDONALD, J.R. Impedance Spectroscopy, emphasizing solid materials and systems. Nova Yorque: Wiley Interscience, 1987. 
(68) BAUERLE, J. E. Study of solid electrolyte polarization by a complex admitance method. Journal of the Physics Chemical Solids, v. 30, p. 2657-2670, (1969).

(69) KOFSTAD, P.K. Nonstoichiometry, diffusion and electrical conductivity in binary metal oxides. Nova Yorque: Wiley Interscience, 1972.

(70) APPEL, C.C.; BONANOS, N. Structural and electrical characterization of silica-containing yttria-stabilized zirconia. Journal of the European Ceramic Society, v. 19, p. 847-851, 1999.

(71) FUJIMORI, H.; YASHIMA, M.; KAKIHANA, M.; YOSHIMURA, M. $\beta$-cubic phase transition of scandia-doped zirconia solid solution: calorimetry, x-ray diffraction, and Raman scattering. Journal of Applied Physics, v. 91, n. 10, p. 6493-6498, 2002.

(72) SHIMAZU, M.; ISOBE, T.; ANDO, S.; HIWATASHI, K.; UENO, A.; YAMAJI, K.; KISHIMOTO, H.; YOKOKAWA, H.; NAKAJIMA, A.; OKADA, K. Stability of $\mathrm{Sc}_{2} \mathrm{O}_{3}$ and $\mathrm{CeO}_{2}$ co-doped $\mathrm{ZrO}_{2}$ electrolyte during the operation of solid oxide fuel cells. Solid State lonics, v. 182, p. 120-126, 2011.

(73) ORAZEM, M.E. TRIBOLLET, B. Electrochemical impedance spectroscopy. John Wiley, New Jersey, 2008.

(74) SMIRNOVA, A.; SADYKOV, V.; MUZYKANTOV, V.; MEZENTSEVA, N.; IVANOV, V.; ZAIKOVSKII, V.; ISHCHENKO, A.; SAMMES, N.; VASYLYEV, O.; KILNER, J.; IRVINE, J.; VERESCHAK, V.; KOSACKI, I.; UVAROV, N.; ZYRYANOV, V. Scandia-stabilized zirconia, effect of dopants on surface/grain boundary segregation and transport properties. In: Materials Research Society Symposium Proceedings, Materials Research Society, v. 972, 0972-AA10-05, 2007. 